\title{
EFEITOS DO ESTIOLAMENTO BASAL, DA JUVENILIDADE E DO USO DE UM REGULADOR VEGETAL NO ENRAIZA- MENTO DE ESTACAS DE RAIZZES E DE RAMOS HERBACEOS DE ALGUMAS ESPÉCIES FRUTIFERAS
}

APARECIDA CONCEIÇÃO BOLIANI

Orientador: Prof. Dr. VLADEMIR RODRIGUES SAMPAIO

Dissertação apresentada à Escola Superior de Agricultura "Luiz de Queiroz", da Universidade de São Paulo, para obtenção do título de Mestre em Agronomia - Ârea de concentração: Fitotecnia.

PIRACICABA

Estado de São Paulo - Brasil

Dezembro - 1986 
Aos meus pais:

ALBERTO e ANTONIA

pelo seu amor, compreensão, conóiança e

apoio constante

OFERE\&O

Aos meus irmãos, irmãs, sobrinhos

e sobrinhas

FRANCISCO, ANTONIO, INEZ, LOURDES

SUNINHA $e$ LENINHA

LUIS ALBERTO, MATHEUS, FELIPE \&

G!ISTAVO

MARCIA, ANA, ELOISE, CAROLINA

e EVELISE

DEE D I C O 


\section{A GRADECIMENTOS}

A autora expressa seus agradecimentos a todas as pessoas $e$ instituiçōes que direta ou indiretamente colaboraram para a realizaçäo deste trabalho, especialmente.

Ao Professor Dr. ULADIMIR RODRIGUES SAMPAIO, pela orientação, amizade e constante incentivo durante o curso e na execução deste trabalho.

Ao professor or. CELIO S. MOREIRA, pela atençäo, incentivo, sugestões e consideraçöes oférecidas no transcorrer do curso.

Ao professor Dr. SALIM SIMAO, pela amizade e sugestões durante o curso.

AOS PROFESSORES do Departamento de Agricultura e Horticultu ra, pelos ensinamentos transmitidos.

Ao Professor Dr. DECIO BARBIN, pelas sugestões e auxilio nas anālises estatisticas.

A escola superior de agricultura "luiz de qUeIROz", da univer sidade de São Paulo, Piracicaba, SP, pela oportunidade de aper beiçoamento. 
Aos COLEgAs do curso de Pós-Graduação, pelo incentivo, amiza de e sugestöes durante o curso.

AOs FUNCIONARIOS do Setor de Horticultura, pela colaboração na execução do experimento.

AOS FUNCIONARIOS da Biblioteca da ESALQ/USP, em especial ao Sr. LUIS CARLOS VERISSTMO, pela solicitude no atendimento.

A FUNDAÇAO de AMPARO A PESQUTSA DO ESTADO dE SAO PALLO e a COORDENAÇAO DE APERFEIÇOAMENTO DE PESSOAL DE NIVEL SUPERIOR, PQ la bolsa concedida, sem a qual não teria sido possivel a reali zaçäo deste trabalho.

A EUCATEX pela doação do substrato vermiculita, utilizado nes ta pesquisa. 
RESUMO

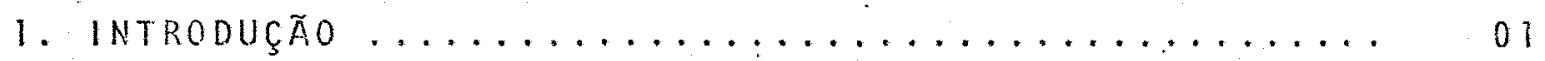

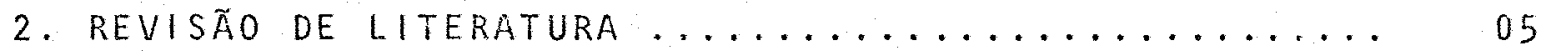

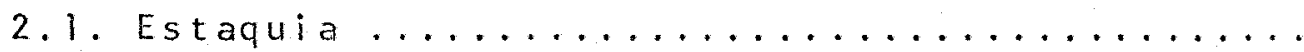

2.2. Fatores que afetam o enraizamentodas, estacas.

2.2.1. Condiçöes Ambientais durante o enraiza. mento das estacas $\ldots \ldots \ldots \ldots \ldots \ldots$

2.2 .1 .1 . Umidade $\ldots \ldots \ldots \ldots \ldots \ldots$

2.2 .1 .2 . Temperatura $\ldots \ldots \ldots \ldots \ldots \ldots$

$2.2 .1 .3 . \operatorname{Luz} \ldots \ldots \ldots \ldots \ldots \ldots \ldots$

2.2.1.4. Substratos para o enraizamento



2.2.2. Condições Fisiológicas das estacas ...

2.2.3. Epoca do ano em que são retiradas as es tacas $\ldots \ldots \ldots \ldots \ldots \ldots \ldots \ldots$

2.2 .4 . Uso de reguladores vegetais $\ldots \ldots \ldots \ldots$

2.2.5. Juvenilidade $\ldots \ldots \ldots \ldots \ldots \ldots \ldots \ldots$ 
Pâgina

3. MATERIAL E METODOS .................. 46

3.1. Condições Locais .................. 46

3.2. EXPERIMENTO 1 - Regeneraçăo de ameixeira atra vés de estacas de ramos herbáceos ...........

3.2.1. Práticas culturais realizadas $\ldots \ldots \ldots$

3.2.2. Retirada e preparo das estacas .......

3.2.3. Local de instalação do experimento ....

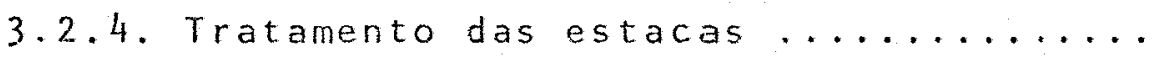

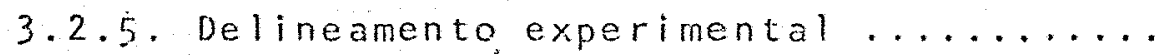

3.2.6. Constatação do enraizamento das esta -

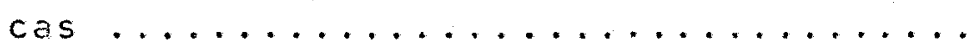

3.3. EXPERIMENTO 2 - Regeneração de nespereira atra



3.3.1. Práticas culturais realizadas ........

3.3.2. Retirada e preparo das estacas .......

3.3.3. Local de instalação do experimento ....

3.3.4. Tratamento das estacas $\ldots \ldots \ldots \ldots \ldots$

3.3.5. Delineamento experimental $\ldots \ldots \ldots \ldots$

3.3.6. Constatação do enraizamento das esta -

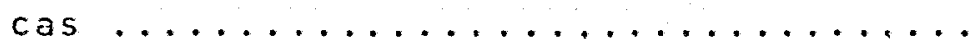


3.4. EXPERINENTO 3-Regeneracăo de pitangueira através de estacas de ramos herbäceos .....

3.4.1. Präticas culturais realizadas ......

3.4.2. Retirada e preparo das estacas.....

3.4.3. Local de instalaçäo do experimento ...



3.4.5. Delineamento experimental $\ldots \ldots \ldots$

3.4.6. Constataçäo do enraizamento ........

3.5. EXPERIMENTO 4 - Regeneração de nogueira pecã através de estacas de raízes ..........

3.5.1. Retirada e preparo das estacas .....

3.5.2. Local de instalação do experimento..

3.5.3. Tratamentos utilizados e plantio das estacas $\ldots \ldots \ldots \ldots \ldots \ldots \ldots$

3.5.4. Delineamento experimental ........

3.5.5. Constatação do enraizamento das estacas.

3.6. EXPERIMENTO 5 - Regeneração de pitangueira

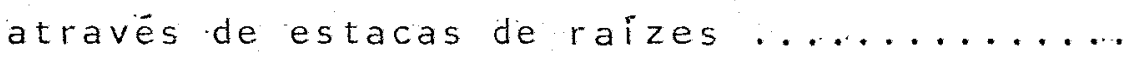

3.6.1. Retirada e preparo das estacas .....

3.6.2. Local de instalação do experimento..

3.6.3. Tratamentos utilizados e plantio das estacas $\ldots \ldots \ldots \ldots \ldots \ldots \ldots \ldots$ 
3.6.4. Delineamento experimental .......... 64

3.6.5. Constatą̧ão do enraizamneto ......... 64

4. RESULTADOS ............................ 65

4.1. EXPERIMENTO I Regeneração de ameixeira atra ves de estacas de ramos herbáceos .......... 65

4.2. EXRERIMENTO 2 - Regeneração de nespereira atravès de estacas de ramos herbäceos .......... 72

4.3. EXPERIMENTO 3 - Regeneração de pitangueira atra vès de estacas de ramos herbáceos .......... 76

4. 4. EXPERIMENTO 4 - Regeneração de nogueira pecã atraves de estacas de raízes ............. 80

4.5. EXPERIMENTO 5 - Regeneração de pintagueira atra vès de estacas de ratzes ............... 84

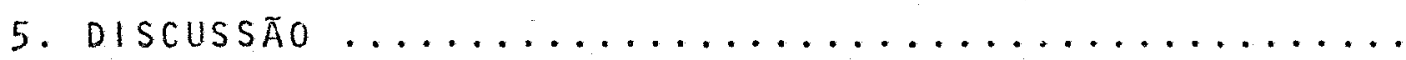

5.1. EXPERIMENTO 1 - Regeneração de ameixeira atra. vés de estacas de ramos herbäceos ...........

5.2. EXPERIMENTO 2 - Regeneração de nespereira atravès de estacas de ramos herbáceos ...........

5.3. EXPERIMENTO 3 - Regeneração de pitangueira atra vés de estacas de ramos herbáceos $\ldots \ldots \ldots \ldots \ldots$

5.4. EXPERIMENTO 4 - Regeneraçäo de nogueira pecã

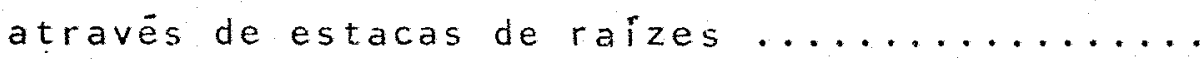


5.5. EXPERIMENTO 5 - Regeneração de pitangueira

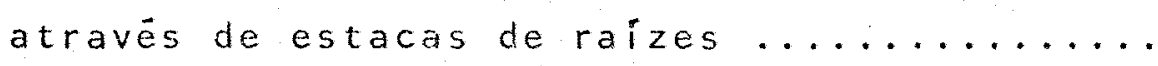



6.1. EXPERIMENTO 1 -Renegeração de ameixeira através de estacas de ramos herbáceos .......

6.2. EXPERIMENTO 2 - Regeneraçäo de nespereira atravës de estacas de ramos herbäceos .......

6.3. EXPERIMENTO 3 - Regeneração de pitangueira através de estacas de ramos herbáceos ......

6.4. EXPERIMENTO 4 - Regeneração de nogueira pecã

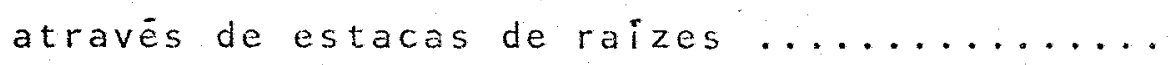

6.5. EXPERIMENTO 5 - Regeneração de pitangueira através de estacas de raízes $\ldots \ldots \ldots \ldots \ldots \ldots$

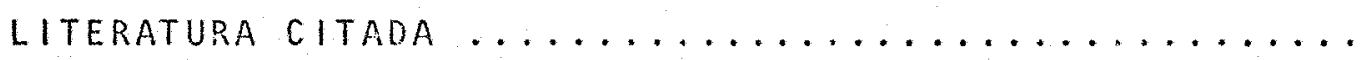


TABELA 1. Anālise da variância do enraizamento das estacàs de ramos herbāceos de ameixeira em diferentes culti vares e diferentes concentrações de AlB .............

TABELA 2. Médias de enraiząmento de estacas de ramos herbäceos de ameixeira, nos diferentes cultivares ...........

TABELA 3. Nümero médio de estacas de ramos herbäceos enraiza das dos diferentes cultivares de ameixa influenciados pelas diferentes concentrações de AlB ...........

TABELA 4. Análise da variäncia do enraizamento das estacas de ramos herbāceos de nespereira, cultivares Mizuho e Precoce de ltaquera, com o uso da técnica do estiolamento associada ao uso de $A / B \ldots \ldots$.

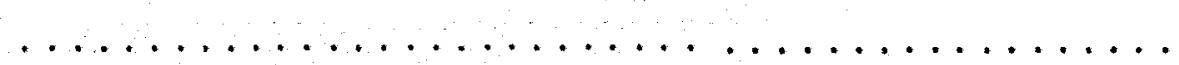

TABELA 5. Número médio de estacas de ramos herbāceos enraizadas de nespereira,cultivares Mizuho e Precoce de Itaquera, dentro do fator estiolamento ....... 
TABELA 6. Análise da variânicia do enraizamento das estacas de ramos herbáceos de pitangueira de materiais juve nil e adulto com diferentes concentrações de

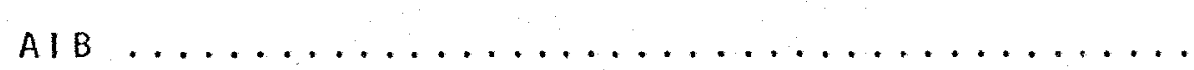

TABELA 7. Mëdias de enraizamento de estacas de ramos herbäceos de pitangueira, de materiais juvenil e adulto, com diferentes concentrações de Als ........ 78

TABELA 8. Anālise da variancia dos dados de enraizamento das estacas obtidas de rafzes de nogueira pecä, de materiais juvenil e adulto com dife -

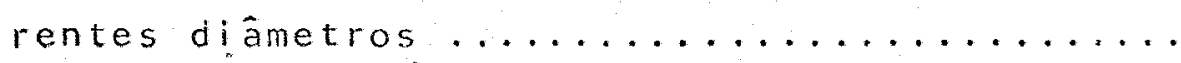

- tabela 9. Médias de enraizamento de estacas obtidas de raízes de nogueira pecá, para materiais juve nil e adulto com estacas de diferentes diâme -

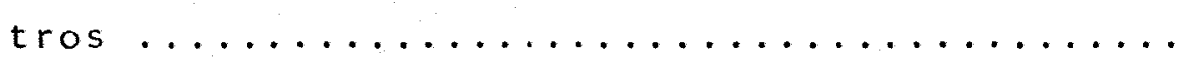

TABELA 10. Médias de enraizamento das estacas de raízes de nogueira pecã com diferentes diâmetros das estacas de materiais juvenil e adulto ....... 
TABELA 11. Anälise da variancia do enraizamento de esta cas de raízes de pitangueira para materiais juvenile adulto, influenciado pelos fatores



TABELA 12. Mëdias de enraizamento de estacas obtidas de raizes de pitangueira de materiais juvenil e adulto, influenciado pelo fator substrato...

TABELA 13. Mëdias de enraizamento das estacas obtidas de raizes de pitangueira de materiais juvenil e adulto, influenciado pelo fator diámetro das

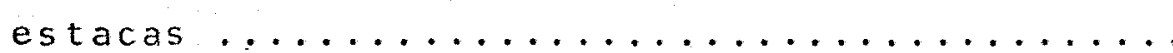

TABELA 14. Resultados das avaliaçöes de enraizamento das estacas de ramos herbáceos de seis cultivares de ameixa, com diferentes concentraçöes de AIB LAPEN

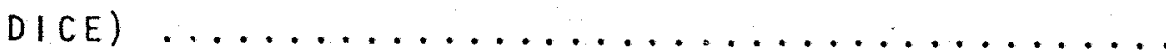

TABELA 15. Resultados das avaliações do nümero de estacas de ramos herbäceós enraizadas de dois cultivares de nêspera: , Mizuho e Precoce de Itaquera, com o uso da técnica do estiolamento e diferentescon centrações de A|B (APEND/CE) ............... 126 
xiti.

Pägina

TABELA 16. Nümero de estacas de ramos harbäceos de pitangueira en raizadas de materiais juvenil e adulto com diferentes concentraçöes de A|B (APENDICE) .....

TABELA 17. Nümero de estacasiderraízes: de innogueíra pecá enraizadas de materiais juvenil e adulto com diferentes diâmetros das estacas(APENDICE).. 128

TABELA 18. Nümero de estacas de raízes de pitangueira obtidas de materiais juvenil e adulto, com diferentes diàmetros e colocadas para enraizamento em diferentes substratos (APENDICE) ........... 


\section{LISTA DE FIGURAS}

Pàgina

FIGURA 1. Nümeros mëdios de estacas de ramós herbäceos enráizadas de seis cultivares de ameixeirae diferentes

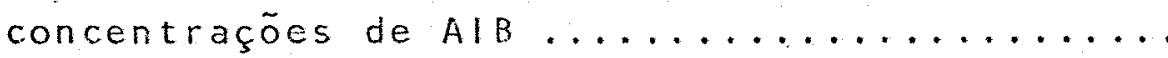

FIGURA 2. Relação entre nümero de estacas de ramos herbáceos enraizadas de ameixeira e concentração de



FIGURA 3. Relação entre nümero de estacas enraizadas de ramos herbáceos de ameixeira e concentração de AlB, para o cultivar Kelsey Paulista ...........

FIGURA 4. Relaçäo entre nümero de estacas de ramos herbäceos enraizadas de nespereira, cultivar Precoce de

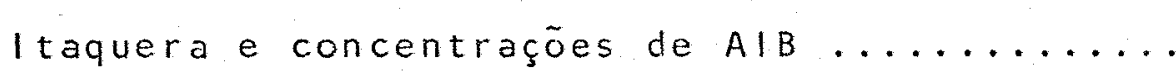

FIGURA 5. Relação entre nümero de estacas de ramos herbáceos de pitangüeira enraizadas de materiais juvenil. e

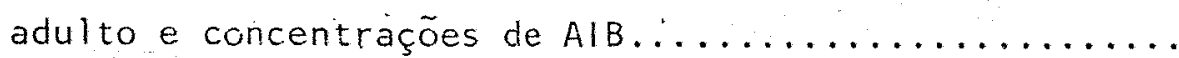

FIGURA 6. Resultados médios de estacas enraizadas de estacas de raízes de nogueira pecã de materiais juvenil e adulto para diferenres diametros das estacas ...... 
FIgura 7. Médias a cada 10 dias das temperaturas mäximas e mínimas, em ${ }^{\circ} \mathrm{C}$ durante os meses de outubro de 1985 a março de 1986, obtidas em casa-de-

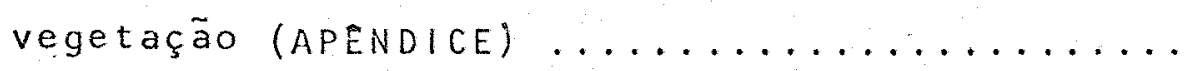

FIGURA 8. Precipitações pluviais mensais em $\mathrm{mm}$, e mēdia mensal das temperaturas mäximas e mínimas, em ${ }^{\circ} \mathrm{C}$ durante o ano de 1984 (APENCICE) ........ 123

FIGURA 9. Precipitações pluviais mensais em $\mathrm{mm}$, e média mensal das temperaturas mäximas e minimas, em ${ }^{\circ} \mathrm{C}$ durante o ano de 1985 (APEND/CE) ....... 124 
EFEITOS DO ESTIOLAMENTO BASAL, DA JUVENILIDADE E DO USO DE UM REGULADOR VEGETAL NO ENRAIZAMENTO DE ESTACAS DE RAIZES E DE RAMOS HERBACEOS DE ALGUMAS ESPECIES FRUTTFERAS

Autor: APARECIDA CONCEIÇÃO BOLIANI orientador: Prof. Or, VLADIMIR RODRIGUES SAMPAIO

\section{RES UMO}

o objetivo deste trabalho foi o de se estudar os efeitos do estiolamento basal, da juvenilidade é do uso de dife rentes concentrações de um regulador vegetal no enroizamento de estacas de raízes e de ramos herbáceos de algumas espécies frutiferas.

Os experimentos foram conduzidos na Escola Superior de Agricultura "Luiz de Queiroz", da Universidade de São Paulo, em Piracicaba, Estado de São Paulo, Brasil.

Estacas de ramos herbäceos de seis cultivares de ameixa (Prunus salicina L.) e dois cultivares de néspera (Erio botrua japonica Lindley), receberam pré-tratamento basal com ácido indol-butírico (A|B) em solução aquosa nas concentrações de:0;2000 e 4000ppm, por 5: segundos. As estacas de ramos herbáceos de dois cultivares de nêspera receberam também pré-tratamento com estiolamento basal. Enquanto as estacas de ramos herbäceos de pitanga (Eugenia uniGlora Lidley), de materiais juvenil e adulto receberam pré-tra 
tamento com AlB em soluçäo aquosa nas concentraçöes de 0; 1000 ; 2000 e 4000 ppm por 5 segundos. Todos os experimentos com esta cas de ramos herbáceos for am conduzidos sob condições de nebuli zaçäo intermitente, durante outubro de 1985 a março de 1986.

Os experimentos com estacas de raizes, consistiu no enraizamento de estacas com diferentes diâmetros, de materiais juvenil e adulto de pitangueira e nogueira pecã (Carya illinoensis Koch) em 'condiçõés de viveiro, no período de julho de 1984 a julho de 1985.

As anàlises dos resultados obtidos permitiram as seguintes conclusões:

a) Os cultivares de ameixa: Carmesin, Gema de Ouro, Grancuore, Golden Talismã, Rosa Paulista e Kelsey Paulista, apresentaram boa capacidade de regeneração atravēs do emprego de estacas herbäceas. As percentagens de regeneração obtidas foram respec tivamente: $88,74 \% ; 85,80 \% ; 79,24 \% ; 58,30 \% ; 58,18 \%$ e $44,02 \%$.

\section{o enraizamento das estacas herbàceas dos dois}

cultivares: Grancuore e Kelsey Paulista foram influenciados com a aplicação de $A \mid B$.

b) As percentagens médias de enraizamento obtidas para os cultivares de nêspera, foram: Mizuho $(46,81 \%)$ e Precoce de 1 taquera $(52,35 \%)$. Houve aumento na percentagem de enraizamento do cultivar Precoce de Itaquera com a aplicação do AlB. 0 uso do estiolamento basal näo influenciou o enraizamento dos dois culti vares. Não houve influência da aplicação do AlB para o cultivar Mizuho. 
c) Os enraizamentos das estacas de ramos herbáceos de pitanguei ra foran respectivamente: $65,64 \%$ e $14,69 \%$ para material juvenil e adulto. o enraizamento do material adulto foi melhorado com - aumento da concentração do AlB.

d) As estacas de rafzes de pitangueira de material juvenil e adulto revelaram percentagens de enraizamento de $17,82 \%$ e $2,00 \%$ respectivamente. 0 uso de diàmetros maiores e menores que 0,5 $\mathrm{cm}$ para material juvenil e maiores e menores que $1,0 \mathrm{~cm}$ para material adulto e uso de diferentes substratos (areia, terra e vermiculita) não influenciaram o enraizamento das estacas.

e) As estacas de raízes de nogueira pecã de materiais juvenil e adulto revelaram percentagens de enraizamento de $91,36 \%$ e $21,13 \%$, respectivamente. Estacas com maiores diâmetros 11,0 a 1,5 e 1,5 a $2,0 \mathrm{~cm}$ ) apresentaram maiores percentagens de enraizamento para os dois materiais, em relação aos menores diame :tros $($ de 0,5 a: $1,0 \mathrm{~cm})$. 
EFFECTS OF BASAL ETIOLATION, JUVENILITY AND THE USE OF A GROWTH REGULATOR ON ROOTING OF SOFTWOOD AND ROOT CUTTINGS OF SOME FRUIT SPECIES

Author: APARE CIDA CONCEIÇÃO BOLIANI Adviser: Prof. Dr. VLADIMIR RODRIGUES SAMPAIO

SUMMARY

The objectives of this work were to study the effects of basal etiolation, juvenility and the use of a growth regulator at different concentrations on rooting of softwood and root cuttings of some fruit species.

The trials were carried out at the School of Agri culture "Luiz de Queiroz", University of São Paulo, in Piracica ba, State of São Paulo, Brazil.

Softwood cuttings of six plum (Prunus salicina L.) cultivars and two loquat (Eriobotrya japonica Lindley) cult vars received basal pre-treatment with indole-3-bytyric acid (1BA) aquous solution concentrations of: $0 ; 2000$ and $4000 \mathrm{ppm}$ for 5 seconds. The cut tings of the two loquat cultivars also received basal etiolation pre-treatment. While, the softwood cuttings from juvenile and adult surinan cherry(Eugênia uniflora Lindley) trees received basal pre-treatment with IBA aquous solutionsat concentrations of: $0 ; 1000 ; 2000$ and 4000 ppm for 5 seconds. All the trials 
with softwood cuttings were carried out under intermitent mist irrigation during october 1985 to march 1986.

The trials with root cuttings consisted of root sections of different diameters from juvenile and adult surinan cherry and pecan (Carya illinoensis Koch) trees and were carnied out under nursery conditions from july 1984 to july 1985.

Analyses of the results allowed for the following conclusions:

a) The cultivars of Carmesin, Gema dè Ouro, Grancuore, Gol den Talismã, Rosa Paulista and Kelsey Paulista, presented a good regenerative capacity using the softwood cuttings. The percentagens obtained were: $88,74 \% ; 85,80 \% ; 79,24 \% ; 58,30 \%$; $58,18 \%$ e $44,02 \%$, respectively.

The rooting of softwood cuttings of two cultivars: Grancuore and Kelsey Paulista were affected with the application of IBA.

b) The average percentage of rooting for the loquat culti vars were: Mizuho $(46,81 \%)$ and Precoce de ltaquera $(52,35 \%)$. There was an increase in the rooting percentage of the precoce de Itaquera cultivar, with the application of IBA. The use of basal etiolation did not affected the rooting of the two cul tivars. There was no registered variation when: IBA was applied to the Mizuho cultivar.

c) The rooting of softwood cuttings of surinam cherry from juvenile and adult material were $65,64 \%$ and $14,69 \%$, respectively. 
Cuttings from adult material revealed an increase proportional to increased application of IBA.

d) The root cuttings of surinam cherry from juvenile and adult material revealed rooting percentages of: $17,82 \%$ and $2,00 \%$ respectively. The use of diameters below and above 0,5 $\mathrm{cm}$ for juvenile material and below and above $1,0 \mathrm{~cm}$ for adult material and different media (sand; soil and vermiculite) did not affect the rooting of cuttings.

e) The root cuttings of pecan from juvenile and adult material revealed rooting percentages of $91,36 \%$ and $21,13 \%$, respec tively. Cuttings with larger diameters $\left(1,0\right.$ a 1,5 and $1,5 a^{2,0}$ $\mathrm{cm}$ ) showed higher rooting percentages than the smaller diameters $(0,5 \mathrm{a} 1,0 \mathrm{~cm})$. 


\section{INTRODUÇÃO}

A dificuldade de obtenção de mudas de boa qualidade constitui sërio problema para o desenvolvimento da fruti cultura brasileira. Trabalhos sobre propagação vegetativa de plantas frutifferas, especialmente de especies pouco estudadas, säo pois importantes e podem constituir-se em real contribuição para o desenvolvimento da fruticultura.

o presente trabalho, busca informações que pode- rão contribuir para o desenvolvimento de técnícas de pro pagação para a ameixeira, nespereira, pitangueira e nogueira pe ca. Estes experimentos buscam respostas relativas aos efeitos causados pela juvenilidade e uso do estiolamento na propagação de plantas, oferecendo contribuições para propagação vegetativa dessas espëcies.

Na fruticultura, a propagação por estacas é muito utilizada. Neste processo, partes dos ramos, das raizes ou das folhas são separadas da planta matriz e colocadas em condi- 
ções ambientais favorăveis, para a regeneração de rafzes e ramos. Produziräo assim, uma nova planta, que na maioria dos casos serä idêntica à planta da qual o material foi obtido (HARTMANN e KESTER, 1975 e HARTMANN et alii, 1981).

A propagação por estacas, proporciona as seguintes vantagens: a) Método räpido e simples; b) Pouco custo so; c) Pode-se obter muitas plantas em curto espaço de tempo, partindo-se de poucas plantas matrizes; d) obtém-se grande uniformidade das plantas e e) As plantas obtidas apresentam exatamente as mesmas caracteristicas das plantas progenitoras, sem apresertarem variação genética. Teria como desvantagem o fato das plantas originadas a partir de estacas terem raízes na maio ria das vezes superficiais, com ausência da raiz pivotante, sen do facilmente arrancadas em regiões sujeitas a ventos fortes.

os principais fatores que afetam o enraizamento das estacas, segundo (KRAMMER e KOZLOWSKI, 1972; HARTMANN e KESTER, 1975 e HARTMANN et alii, 1981), são: condições ambien tais durante o enraizamento das estacas, condições fisiológicas das estacas; época do ano en que são retiradas as estacas; uso de reguladores vegetais; juvenilidade e estiolamento.

A formação de raf́zes nas estacas, depende das condições internas da planta matriz e do meio em que são colocadas. Pouco se sabe sobre os fatores internos, embora seja evidente que a condição fisiológica da planta assume, frequente mente importáncia fundamental em virtude das estacas de uma 
mesma planta poderem lançar mais facilmente raizes, em uma de terminada época do que em outras, seja qual for o tratamento a que são submetidas (HARTMANN E KESTER, 1975).

\section{Algumas espécies lançam rafizes com facilidade,}

embora seu enraizamento seja normalmente melhorado mediante tra tamento com regulador vegetal que estimula o crescimento radicular, porém outras espëcies carecem deste tratamento.

Os objetivos de se tratar as estacas com regulador ve getal tem sido: aumentar a percentagem de estacas que formem rai zes, acelerar a formação das mesmas, aumentar o nümero e melhorar a qualidade das raízes formadas em cada estaca e aumentar a uniformidade do enraizamento.

Värias técnicas tem sido utilizadas com o objeti vo de obtenção de melhoria no processo de enraizamento. Entre elas, o uso da juvenilidade e da técnica de estiolamento.

Värios trabalhos foram realizados por alguns autores em diferentes espëcies, comparando-se capacidade de enra zamento de estacas obtidas a partir de materiais juvenil e adul to, e todos obtiveram melhores resultados quando utilizaram estacas de material juvenil.

Estiolamento vem a ser o desenvolvimento de brotos, ramos, ou partes dos ramos em ausência de luz, causando um crescimento normalmente alongado, com coloração branca ou amare la devido a ausência de clorofila. Não estão ainda bem definidos quais os efeitos prejudiciais da luz no enraizamento das 
estacas, podendo serem devido a fotoinativação ou outros fatores naturais de enraizamento nos tecidos cortados do caule (HARTMANN et alii, 1981).

o objetivo deste trabalho foi de verificar a capacidade de regeneração de algumas plantas frutíferas: de ameixeira, nêspereira, pi tangueira e noguẹira pecã, atravēs de estacas de ramos herbáceos e de raízes, aplicando-se técnicas como juvenilidade, estiolamento e uso de regu lador vegetal.

As estacas de ramos herbáceos de seis cultivares de ameixa (Prunus salicina L.) e dois cultivares de nêspera (Eriobotrya japonica L.) receberam prē-tratamento basal com AlB em solução aquosa, nas concen traçōes de 0;2000 e 4000 ppm por 5 segundos. As estacas de ramos herbáceos de dois cultivares de nêspera receberam também pré-tratamento com estiolamento basal. Enquanto as estacas de ramos herbäceos de pitangueira (Eugenia uniflora Lindley), de materiais juvenil e adulto receberam pré tratamento com AlB em solução aquosa nas concentrações de $0,1000,2000$ e $4000 \mathrm{ppm}$. Todos os experimentos com estacas de ramos herbáceos foram conduzidos sob condições de nebulização intermitente.

Os experimentos com estacas de raízes, consistiu no enra! zamento de estacas com diferentes diâmetros, de materiais juvenil e adulto de pitangueira e nogueira pecã (Carya illinoensis Koch), en condições de viveiro. 
2. REVISÃO DE LITERATURA

Existem dois tipos bäsicos de propagaçäo de plan tas: o sexual e o assexual.

A propagação sexual vem a ser a uniäo de células sexuais masculinas e femininas, tendo como resultado, a formação de sementes e a criação de indivíduos comi novos genótipos (HARTMANN E KESTER, 1975).

KOLENISKOV (1964) e tambēm värios outros auto res citam que esse tipo de propagação é muito utilizado com o objetivo de se obter novos cultivares por hibridação e tam bém em plantas que não se propagam por outromeio.

A propagação assexual, por sua vez, consiste na reprodução de individuos a partir de porçōes vegetativas das plantas matrizes, e é possível porque muitos destes órgãos vegetativos têm capacidade de formar novas raízes a as raízes por sua vez podem regenerar novos ramos e raizes (HARTMANN e KESTER, 1975). 
SIMÃo (1971) diz que a propagação assexual é baseada na capacidade de regeneração de um vegetal, a partir de cêlulas somāticas.

Alguns autores, entre eles HARTMANN e KESTER (1975), WRIGHT (1975) e HARTMANN et alii (1981), afirmam que a propagação assexual é possível porque a divisão celular (mitose) ocorre durante a regeneração e o crescimento. Esta multiplicação ocorre com facilidade em plantas superiores.

No processo da mitose, resulta que as caracteristicas da nova planta que se desenvolve são as mesmas daquela que a originou (HARTMANN e KESTER, 1975).

A razão principal para empregar a propagação vegetativa è que são reproduzidas em forma exata as característi cas de qualquer planta individual. (HARTMANN e KESTER, 1975); (HARTMANN et alii, 1981).

SANTOS (1968) afirma que a principal vantagem da propagação vegetativa é o fato de saber-se que o vegetal produ zido é igual aquele que the deu origem. Alén do mais, esse processo de reprodução é incontestavelmente mais rápido que o sexual.

Dentre os processos de propagação assexual, os principais são: estaquia, mergulhia, alporquia e enxertia. (SAN TOS, 1968 ; SIMÃO, 1971 e outros). 


\subsection{Estaquia}

Na fruticultura, à propagação por estacas é mui to utilizada. Neste processo, partes dos ramos, das ralzes ou das folhas, são separadas da planta matriz e colocadas em condições ambientais favoráveis, para a regeneração de raízes e ramos, produzindo assin, una nova planta, que na maioria dos casos, é idêntica à planta da qual o material foi obtido (HARTMANN E KESTER, 1975; WRIGHT, 1975 e HARTMANN et alii, $1981)$

SIMÃO (1971) comenta que a propagação por esta cas baseia-se na faculdade de regeneração dos tecidos e emis são de raízes. A estaca ou fragmento dela, deve conter no mínimo uma gema que ë. destacada da planta e colocada no subs trato para enraizamento.

Esse mètodo de propagação é de grande importân cia na horticultura; na propagação de plantas herbäceas e lenho sas de muitas espécies frutiferas, ornamentais, tanto de fo Ihas perenes como caducifolias; além de ser utilizada também em algumas hortaliças (WRIGHT, 1975 e HARTMANN et alii, 1981). HARTMANN e KESTER (1975) e värios outros auto res, apresentam as seguintes vantagens para esse tipo de propa gação: a) Método räpido e simples; b) Pouco custoso; c) Pode - 
- se obter muitas plantas em um curto espaço de tempo, partin do-se de poucas plantas matrizes; d) obtem-se grande uniformidade das plantas e e) As plantas obtidas apresentam exatamente as mesmas características das plantas progenitoras, sem variação genética.

Por outro lado, GRUNBERG (1928) afirma como desvantagem o fato das plantas originadas a partir de estacas, te rem raizes na maioria das vezes superficiais, com ausencia da raiz pivotante, sendo facilmente arrancadas em regiões sujei tas a ventos fortes.

DIAZ e SANTIAGO (1978), por sua vez, dizem também que outra desvantagem, é o fato de ser maior a possibilida de de propagação de patógenos.

HARTMANN et aliR (1981); WRIGHT (1975); FRETZ et alii (1979) e HARTMANN et alii (1981), fazem uma divisão em rélação aos värios tipos de estacas:
a) de ramos
lenhosa
caducifolias
perenes
semi-lenhosa.
herbàcea
de folthas
de folhas com gemas

b) de raizes 


\subsection{Fatores que Afetam o Enraizamento das Estacas}

A formação de raízes nas estacas, depende das condições internas da planta-matriz e do meio em que são colocadas. Pouco se sabe sobre os fatores internos, embora seja evidente que a condição fisiolögica de planta assume, frequentemente, importáncia fundamental em virtude das estacas de uma mesma planta poderem lançar mais facilmente raízes, em uma determinada época do que em outras épocas, seja qual for o trata mento a que são submetidas (HARTMANN e KESTER, 1975).

As estacas obtidas de plantas novas enraizam geralmente melhor do que as estacas de plantas adultas (KRAMMER e KOZI.OWSKI, 1972).

SIMÃO (1971) e KRAMMER e KOZLOWSKI (1972) afir mam que as condições internas e do ambiente influenciam na for mação das raízes.

Existem grandes diferenças entre espēcies e entre clones, na capacidade de enraizamento das estacas tomadas deles. E difícil saber de antemão, se as estacas tomadas de um determinado clone, enraizaräo ou não com facilidade. As relações botânicas dão uma indicação geral, mas è necessārio fazer-se testes com cada clone. Isto já se tem feito na maioria das plantas de importância económica. As estacas de al = guns cultivares enraízam com tanta facilidade, que com as mais simples instalações se pode obter alta percentagem de enraiza - 
mento. Por outro lado, em muitas espécies e cultivares. não tem sido possível fazer enraizar em nenhuma circunstância. As estacas de outras espécies de difícil enraizamento, podem en raizar de forma satisfatōria, se condicionadas aos diversos fa tores que influenciam o enraizamento.

os princípios e principais fatores que afetam o enraizamento das estacas, segundo.(SIMÃO, 1971; KRAMMER e KOZLOWSKI, 1972; . HARTMANN E KESTER, 1975; WRIGHT, 1975; FRETZ et alii, 1979 e HARTMANN et alii, 1981), são:

a. Condições ambientais durante o enraizamento das estacas

b. Condições fisiolögicas das estacas

c. Epoca do ano em que são retiradas as estacas

d. Uso de reguladores vegetais

e. Juvenilidade

f. Estiolamento

2.2.1. Condições Ambientais Durante o Enraizamento das Estacas

Para o bom desenvolvimento das raízes das esta cas são de grande importáncia: umidade adequada no substrato e na atmosfera, a temperatura e a luz (KRAMMER e KOZLOWSKI, 1972; HARTMANN e KESTER, 1975 e HARTMANN et alii, alöm de outros-). 


\section{2 .1 .1 . Unidade}

A umidade vem a ser um dos fatores mais importán tes para o enraizamento das estacas, pois na auséncia desta, haverá o murchamento e morte das estacas.

A presença de follas em estacas é um forte estímulo para a iniciação das raízes (HARTMANN et alíi, 1975).

Em espécies que enraf́zam com facilidade, a forma ção rāpida das raízes permite que a absorção da āgua compense a quantidade que è eliminada pelas folhas; porém, em espécies de enraizamento mais lento, deve-se reduzir a transpiração das folhas a niveis muito baixos para que se formem as raízes. Pa ra reduzir ao mínimo a transpiração das folhas das estacas, a pressão de vapor da atmosfera que as rodela deve menter-se semelhante à pressão da água existente nos espaços intercelula res da folha (HARTMANN e KESTER, 1975).

Há muito tempo vem sendo utilizada a casa-de-vegetação, onde hà aspersão de àgua nas estacas, assim como nas paredes e nos pisos para manter uma umidade elevada, dispondo- se atualmente de sistemas de operaçào automätica, que nebulizam a àgua. Esses nebulizadores têm um efeito benēfico princi palmente porque aumentam o conteüdo de vapor de àgua do ar (HARTMANN et alii, 1981).

EVANS (1951) afirma que foi a partir de 1940, que houve o aparecimento de técnicas para enraizar sob nebulizado- 
res. Esses nebulizadores, mantêm sobre as folhas, uma película de água; a qual produz alta umidade relativa ao redor das folhas. Reduz também a temperatura do ar e das folhas, fatores esses que tendem a reduzir a taxa de transpiração. Jäfoi observado que as folhas mantidas sob nebulização apresentam temperatura de $5,5^{\circ} \mathrm{C}$ a $10^{\circ} \mathrm{C}$ mais bajxas que as sen nebulização.

Verificou-se tambēm que a temperatura dos cantei ros sob aspersão, manteve-se praticamente uniforme, ao redor de $18^{\circ} \mathrm{C}$. Em Canteiros sem nebulização com polietileno, nas ho ras mais quentes do dia, a temperatura chegou a $28^{\circ} \mathrm{C}$ (HARTMANN e KESTER, 1975).

Sob nebulização, as condições são ideais para o enraizamento e crescimento de estacas com folhas. Assim a transpiração é reduzida a nível baixo, porèm a intensidade luminosa pode ser alta, promovendo com isso, maior atividade fotossintética. A temperatura da estaca se mantēm relativamente baixa, reduzindo-se a taxa de transpiração (HARTMANN et alii, 1981).

Vărios autores afirmam que a nebulização intermi tente é, sem dūvida, indispensável para o enraizamento de algu mas espécies em regióes tropicais e sub troplcais, onde transpiração foliar é muito intensa durante o dia. Contudo alguns cuidados devem ser tomados, em vista de perda de nutrientes, decorrente da lixiviação das folhas, quando submeti das à nebulização por períodos prolongados. 
ALLAN (1973) dä como boa característica da nebulização, o fato de ela manter a estaca türgida, evitando o murchamento.

DIAZ e SANTIAGO (1978), trabalhando com espécies florestais, verificaram que este sistema foi indispensävel pa ra a manutenção das estacas vivas até a formação das raízes.

NUNES et alii (1982), afirmaram que a nebuliza ção abrevia o tempo de obtenção de estacas enraizadas.

\subsubsection{Temperatura}

Temperaturas diurnas de 21 a $27^{\circ} \mathrm{C}$, com temperatu ras noturnas ao redor de $15^{\circ} \mathrm{C}$, são ideais para enraizar esta cas da maioria das espécies, se bem que algumas enraizam me Ihor com temperaturas mais baixas. Deve-se evitar temperatura do ar demasiadamente alta, pois tende a estimular o desen volvimento das gemas antes do desenvolvimento das raizes e aumenta a perda de àgua pelas folhas. A temperatura pode regu lar a produção de raizes adventícias. E importante que o desenvolvimento das raízes se faça antes do crescimento dos ramos. Calor aplicado na base das estacas, para mantê-las com uma temperatura superior a das gemas, induz, primeiramente, o desenvolvimento das raízes (HARTMANN e KESTER, 1975).

SIMÃO (1971) E KRAMMER E KOZLOWSKI (1972) afirmam que o enraizamento é favorecido pela temperatura em torno 
de $25^{\circ} \mathrm{C}$, por estimular a divisäo celular.

HARTMANN e KESTER (1975) recomendam manter a ba se das estacas à temperaturas mais altas, cerca de $6^{\circ} \mathrm{C}$ de dife rença em relação ao topo para assegurar os seus enraizamentos antes do crescimento dos brotos. Os valores ötimos seriam $24^{\circ} \mathrm{C} e 18^{\circ} \mathrm{C}$, respectivamente.

Baseados nisso, SYKES e HOWARD (1969), trabalhan do com estacas defigueira, observaram maior porcentagem de esta cas brotadas em relação às enraizadas, provavelmente, devido a temperaturas ambientais mais elevadas que as temperaturas do substrato.

\section{$2 \cdot 2 \cdot 1 \cdot 3 . \operatorname{Luz}$}

Em todos os tipos de crescimento das plantas, a luz é o fator de importância primordial, já que è a fonte de energia na realização da fotossintese. No enraizamento de estacas com folhas, os produtos da fotossintese são importan tes para a iniciação e o crescimento das ralzes. A intensida de e duração da luz devem ser suficientes para que se produzam carboidratos em excesso, os quais são utilizados na respiração (HARTMANN E KESTER, 1975).

Existem indicações de que o fotoperíodo em que se desenvolve a planta pode exercer influência tambëm sobre o enraizamento das estacas dela obtidas, podendo em alguns ca- 
sos, estar relacionado com o acúmulo de carboidratos, obtendo-se com frequencia, melhor enraizamento com fotoperíodos que favorecem o aumento de carboidratos (SALISBURY e ROSS, 1978. ; HARTMANN et alii, 1981).

2.2.1.4. Substratos para o enraizamento das estacas

Muitas estacas enraízam com facilidade em diversos meios. Porém, em algumas plantas cujas estacas enraizam com dificuldade, o meio pode influenciar bastante a percenta gem de enraizamento e a qualidade do sistema radicular. 0 uso de substrato adequado melhora o enraizamento e a qualidade do sistema radicular (HARTMANN e KESTER, 19,5 e outros).

Ainda HARTMANN e KESTER (1975) citam trés fun ções do meio de enraizamento: 1) Sustentar as estacas durante - período de enraizamento; 2) Proporcionar umidade às estacas; 3) Permitir penetração de ar na base das mesmas.

Meio ideal de enraizamento é o que tem suficiente porosidade para permitir boa aeração e capacidade elevada de retenção de àgua, porēm, deverā estar bem drenado e livre de agentes patogénicos (SIMÃo, 1971).

Ainda HARTMANN e KESTER, (1975) afirmam que desde há muito tempo, se sabe que o tipo de meio de enraizamento po de afetar o sistema radicular que sustenta as estacas. Exem plificando, quando usada somente a areia como susbtrato de en- 
raizamento, värias espécies de plantas produziram raízes grossase pouco ramificadas. Utilizando-se areia com turfa as raízes foram bem ramificadas, delgadas e mais flexíveis, sendo mais desejäveis para operação de transplante.

HARTMANN e KESTER (1975) relataram que alguns au tores efetuaram estudos comparativos para determinar quais os fatores que influenciam no tipo de sistema radicular, em và rias espécies e observaram que a diferença no tipo de sistema radicular estava baseada no conteúdo de umidade de cada meio. Ainda realizaram observações em relação ao conteüdo de ar $\epsilon$ concluiram que a turfa continha o dobro de ar e o triplo de umidade que a areia. Puderam concluir que o tipo de sistema radicular fino mais desejävel, estava associado ao aumento de umidade no substrato de enraizamento.

SIMÃo (197!) afirma que, as estacas secam, se. o substrato não foi bem provido de àgua; porēm, o excesso de ägua dificulta as trocas gasosas, impedindo o enraizamento e provocando a morte dos tecidos.

De acordo com diversos autores, existem vários substratos que podem ser utilizados isoladamente ou combina dos. Entre eles, destacam-se:solo, areia, vermiculita, esfagno e xaxim, sendo que o uso da vermiculita, yem se destacan do cada vez mais.

Värios autores, entre eles plaut (1980), citado por MINAMI (s.d.), enumeraram algumas propriedades da vermicu- 
lita, que são favoräeis ao enralzamento: capacidade de absorver atë 5 vezes o seu peso em ägua; ë insoluvel em ägua; pH le vemente alcalino; alta capacidade cationica; alta capacidade tampão; com teor razoävel de $K$ e $M g$ e totalmente esterilizado.

Esses substratos têm sido usado para alterar as propriedades do solo. A adição de vermiculita tem aumentado a quantidade de potässio no solo e na planta (DUNHAM, 1967 e BOODLEY e SHELDRAKE JR., 1969), ao pas.so que a adição de turfa e esfagno tem diminuido a quantidade desse mesmo elemento. (DUNHAM, 1967).

A mistura de diferentes substratos tem sido utilizada para o enraizamento de estacas de värias espécies (kosTEWICZ e LOCASC10, 1967 e FERNANDES et alii, 1983).

De acordo com Moreira e Minami (1972), citados por MINAMI (s.d.), para enraizamento de Hidrangea hortencia, a vermiculita pura foi melhor do que a mistura solo argilosomterriço. Para o enraizamen to de estacas de bico-de-papagaio (Euphorbia pulcheruma L.), a mistura de esfagno $(50 \%)$ e vermiculita $(50 \%)$ deu ótimos resultados, segundo Suley e Plaut (s.d.), citados por MINAMI (s.d.).

Estudou-se a aplicação de värias combinações para o enraizamento de estacas de Eucaliptus grandis. Foram ut lizados solo de mata + solo de cerrado e a combinação destes com esterco de curral e vermiculita. Verificou-se que o ester co de curral pode ser substituído com sucesso pela vermiculi- 
ta; observou-se tambëm que no solo de mata, a adição da vermi culita ofereceu melhores condiföes de crescimento para as mudas do que o esterco, sendo que no solo de cerrado, o efeito da vermiculita foi semelhante ao do esterco (DIAS, 1973).

MINAMI (s.d.) afirma que a vantagem da vermiculi ta como meio de germinação, eâde poder reduzir o número de ir rigações, sem afetar a disponibilidade de água às plantas, sendo que para se fazer o transplante e a repicagem, as mudas são facil mente destacadas.

\subsubsection{Condições Fisiolögicas das Estacas}

A relação entre os níveis de carboidratos e nitrogênio é fator importante no enraizamento, bem como hä uma estreita correlação entre o conteüdo de amido e a formação de calos (SIMAOO, 1971 e KRAMMER e KOZLOWSKI, 1972).

HARTMANN E KESTER (1975) afirmam que o conteüdo de carboidratos das estacas, pode ser determinado pela firmeza do ramo. Aqueles ramos que tèm uma concentraçäo indesejavelmen te baixa de carboidratos, são flexíveis; por outro lado, os mais ricos em carboidratos são firmes e rígidos e se dobrados, eles se rompem mais do que se flexionam. Estafirmeza pode ser confundida com a rigidez causada pela maturação dos tecidos, maturação esta, acasionada pelo engrossamento 
e pela lignificação das paredes celulares. Um.método mais exato para determinar o conteüdo de amido desejävel, é o empre go de iodo, onde as partes recen formadas são colocadas por um minuto em solução de $0,2 \%$ de iodo ou iodeto de potässio. As estacas com maior conteüdo de amido terão cor mais escura, per mitindo-se fazer uma classificação, dividindo-se as estacas me dianas, ricas e pobres em carboidratos.

STOUTEMEYER E O'ROURKE (1945) trabalhando com es tacas de videira obtiveram $63 \%$ de enraizamento das estacas ricas em carboldratos e apenas $17 \%$ daquelas com quantidade media na.

\subsubsection{Epoca do ano em que são retiradas as estacas}

A época do ano em que são retiradas as estacas, pode, em alguns casos exercer grande influência no enraizamento destas e pode proporcionar a chave para um enraizamento com bastante éxito. Sabe-se que é possivel fazer estacas durante - ano todo. Porém, ao propagar espécies decíduas, as estacas de madeira semi-lenhosas ou herbäceas com follhas, podem ser preparadas durante a estação de crescimento. As espécies sempreverdes, tanto de folhas estreitas, como largas, têm duran te o ano, um ou mais período de crescimento e podem-se obter estacas em diversas épocas relacionadas com essas temporadas de desenvolvimento (HARTMANN e KESTER, 1975). Deve-se observar 
que para cada planta especifica, necessitam-se de observações à respeito da época ótima de retirada, a qual, com toda possibilidade, estä mais relacionada com a condição fisiolögi ca do tecido vegetal, influenciada pela época do ano.

HARTMANN et alie (1981) afirmam que a época de propagaçäo das estacas, varia bastante, seja quanto a espécie em questão, seja quanto ao tipo de estaca. Assim, as estacas herbäceas seriam retiradas, no período das äguas e mesmo durante o ano todo. Existem casos especiais contudo de estacas, que enraízam melhor quando coletadas no inf́cio da primavera. Jä as estacas lenhosas, em geral, oferecem melhores resultados quando coletadas no período de repouso vegetativo, pois a quantidade de susbtáncias de reserva deste tipo de estacias será maior nos ramos outonados.

De acordo com KozLOWSkl. (1971), algumas espécies enraizam bem quando colhidas ao longo do período de várias semanas a värios meses, porem, en estacas de outras espëcies pa ra que o enraizamento seja bem sucedido, têm que ser obtidas dentro de um período crítico que pode durar apenas de uma a duas semanas.

HARTMANN E KESTER. (1975) generalizam para cada tipo de estaca, uma época para a sua retirada. As estacas de madeira dura, de espëcies caducifolias são retiradas na estação de repouso,que vai de flnal de inverno ao começo da prinavera, utilizando madeiras de ramos 
da estação anterior de crescimento. Estacas de madeira dura e de espëcies de follhas estreitas, sempre verdes, deven ser ob tidas entre o outono e fins de inverno, tomando-se o cuidado de plantä-las logo apōs a sua retirada. Jä as estacas semi - duras com folhas largas, deverão ser coletadas durante os meses de verão é de ramos novos, logo depois do período de crescimento e com a madeira parcialmente amadurecida. por outro lado, as estacas de madeira mole säo aquelas de crescimento primaveril novo e suculento. A melhor maneira de se obter estacas de raízes, é retirä-las de plantas com 2 a 3 anos de ida de em fins de inverno ou começo da primavera, quando as esta cas estarão com bastante reserva (HARTMANN e KESTER, 1975).

\subsubsection{Uso de Reguladores Vegetais}

As estacas de algumas espëcies lançam raizes com facilidade, embora seu enraizamento seja normalmente melhorado mediante tratamento com substâncias que estimulam o crescimento radicular. Outras espêcies pàra enraizarem carecem deste tratamento (SIMÃO, 197I; KRAMMER e KOZLOWSKI, 1975; HARTMANN et alii, 1981 e WARE ING, 1982).

Segundo HANSEN E HARTMANN (1966); KRAMMER KOZLOWSKI (1972); HARTMANN E KESTER (1975) e WAREING (1982), OS objetivos de se tratar as estacas com reguladores vegetais. são: aumentąr a percentagem de estacas que formem raízes;acelerar a formação das mesmas, aumentar o nümero e a qualidade 
das raízes formadas em cada estaca e aumentar a uniformidade do enraizamento.

De acordo com KRAMMER e KOZLOWSKl (1972), apōs - tratamento da base da estaca com uma substáncia que estimule o crescimento radicular, os hidratos de carbono são trans portados para a àrea tratada, a intensidade da respiração au. menta e däo-se transformaçös de hidratos de carbono e de compostos orgänicos nitrogenados. Há o aceleramento do metabolis mo normal a aumento do nümero de primördios radiculares.

$$
\text { HILLER (1951) e KRAMMER e KOZLOWSKI (1972) afir- }
$$
mam que o desenvolvimento morfolögico das novas rárzes é semeThante ao que se verifica nas estacas não tratadas com reguladores, só que com o uso do regulador esse desenvolvimento é acelerado. Parece que um abastecimento natural de auxina proveniente do ápice, da estaca, estimula o enraizamento, uma vez que a retirada de suas gemas, provoca, normalmente a redução do tecido cicatricial e do início da formação do sistema radicular.

Os àcidos indol-butírico (A|B), naftalenoacético (ANA) e o indol-acético (A|A), os seus sais e esteres de potás sio são habitualmente os mais utilizados no tratamento das estacas com vista a um melhor enraizamento. Algumas espécies respondem melhor a um ou mais destes compostos do que ou tras. Em geral, o äcido indol-butírico dä bons resultados com estacas de muitas espēcies. E importante utilizar concentrações cor 
retas, sendo que a concentração ötima varía com as espécies. Em algumas, o enraizamento é ainda mais estimulado, quando os reguladores vegetais estäo misturados à nutrientes minerais ou fungicidas. (KRAMHER e KOZLOWSK1, 1972 e HARTMANN KESTER, 1975). Das formulações encontradas, os ácidos parecem ser os mais eficazes, seguidos dos sais e, por ültimo, pelos esteres.

KRAMMER E KOZLOWSKI (1972) e PADUA (1983), dizem que estes reguladores de crescimento podem ser aplicados de três maneiras: soluçöes diluílas; misturados em talco; ou em pasta.

Soluções dilứdas: conforme a concentração, as estacas são imersas na base, e quanto maior a concentração menor o tempo de imersão.

Miscurados em talco: umidecer a base das estacas para favorecer a aderência da mistura.

Pastas: junta-se lanolina ao regulador e apli... ca-se na base da estaca.

A aplicação dos reguladores em alta concentra ção, tem uma série de vantagens, como: equipamento menor para a aplicação, uniformidade de aplicação e maior rapidez na operação (HARTMANN e KESTER, 1975).

As concentraçōes a serem empregadas, segundo HARTMANN e KESTER (1975) e WAREING (1982), variam de acordo 
com a solução. Geralmente em soluçōes diluídas, asconcentra ções podem variar entre 20 ppm para espécies que enraízam com facilidade e 200 ppm para as espëcies mais difíceis; já em so luçöes concentradas variam de 500 a 10000 ppm.

A concentração utilizada varia também com a es pécie da planta e é muito crítica, o que vale dizer que as concentraçoes devem serbem calculadas, podendo-se tratar as estacas por várias horas, em soluções diluídas, ou por apenas alguns segundos, em soluções concentradas. (HARTMANN e KESTER, 1975).

Existem evidéncias de que um dos hormônios naturais de crescimento, a auxina, é essencial para promover o enraizamento. Materiais originados das folhas, chamados de cofa tores de enraizamento são aceitos como fator essencial para o enraizamento. Eles combinam com a auxina paraformar complexos que se ligam com RNA para ativar enzimas que provocaräo o início do enraizamento. (KRAMMER e KOZLOWSKI, 1972 e HARTMANN e KESTER, 1975). Afi rmam esses autores que a composição des sès cofatores näo è bem conhecida.

outros hormónios, como as giberelinas e o äcido abcísico, também influenciam na formação de raízes adventícias. Ten sido mostrado, tambēm, que açūcares, nitrogênio, cälcio e outros nutrientes minerais presentes, devem influenciar na for mação da raiz (KRAMMER e KOZLOWSKI, 1972 e WEIVER, 1972).

WEAVER (1972) indica que para se determinar o melhor material e a concentração ötima para o enraizamento de 
uma determinada espëcie, deve-se fazer testes preliminares, pois, a aplicação de auxinas em altas concentrações, pode inibir o desenvolvimento das mesmas.

Baseando-se nas vantagens que podem ser obtidas atravēs do uso de reguladores vegetais, ccomo maior por centagem de estacas enraizadas, maior nümero de raf́zes por estacas e maiores comprimentos das raízes, värios trabalhos fo ram realizados em várias espécies.

Värios autores obtiveram exelentes resultados em espécies diferentes, utilizando-se AlB em diferentes concentra ções, entre eles: MAXIMOS et åil (1966) com estacas de pesseguei ro SINGH e GAUR (1966) de goiabeira SEN et alii (1969)de mangueira TEHRANI e LOGAM (1971); NAHLAWI e HOWARD (1971 e 1972) ; BARTOLINI e ROSELLI (1975) e PATHAK et alie (1975) com esta cas de ameixeira BAJWA et alie (1977) com citrus limetticides Ta naka; ECCHER e FORMENTI (1974) com Prunus sinensis; SHARMA (1975) de goiabeira REDDY e MAJUMDER (1975) com estacas de goiabei ra e ERNST: e HCLTZHANSEN (1978) de abacateiro além de outros.

Alguns trabalhos foram realizados, mas verifi cou-se que näo houve grande aumento na percentagem de enraizamento. BOURDEAUT (1970), trabalhando com porta-enxertos de ábacateiromexicano, utilizando 2000 e 3000 ppm de AlB, verificou que não houve grande aumento na percentagem de enraizamento.

Alguns autores fizeram testes, para observar quais as melhores concentrações de auxina a serem utilizadas 
em estacas de ameixeira; assim, TEHRANI e LOGAM (1971); NAHLAWI e HOWARD (1971 e 1972); BARTOLINI e ROSELLI (1975); NICOTRA e DAMINO (1975) e PATHAK et alii (1975), utilizando concentra ções variāveis de 500 a $5000 \mathrm{ppm}$ de AlB chegaramà conclusão de que 2000 e 2500 ppm foram as melhores concentrações.

BAJWA et alii(1977)trabalhando com estacaside Citrus ut i lizaram concentrações de 0 a 200 ppm de AlB e os melhores re sultados foram obtidos com $100 \mathrm{ppm}$.

SHARMA (1975) por sua vez, recomenda 200 ppm pa ra estacas herbàceas de goiabeira.

REDDY e MAJUNDER (1975) realizando trabalhos com esta cas de mangueira cultivar Dashehari e goiabeira cultivar Alla habad Safeda, recomendaram5000 ppm de AlBcomo a melhor concentração.

NAHLAWI e HOWARD (1972) realizaram estudos, tentando verificar qual a melhor duração dos tratamentos e verifi caram que para altas concentraçōes, 5 segundos se mostrou mais eficiente, e para baixas concentrações, 24 horas.

SULLADMATH e KOLOLGI (1969) trabalhando com al.porquia em Achras zapota, durante dois anos, utilizaram AlA, $A \mid B$, ANA e AIB + ANA em concentrações de 5000 a 20000 ppm. - A percentagem mais alta de enraizamento foi de $90 \%$ e obtido com AlB + NAA, a $10000 \mathrm{ppm}$, com o enraizamento ocorrendo 6 semanas após o tratamento, ao passo que no cootrole ocor reu $40 \%$ de enraizamento após $38-40$ semanas. 
BHARATH (1970) trabalhando com estacas de goiabeira, obteve $90 \%$ de pegamento quando utilizou AlB + NAA na concentração de $6000 \mathrm{ppm}$. Melhores resultados com AlB + NAA também foram obtidos por CHAUHAN e PUNDIR (1972) trabalhando com estacas de pe segueiro.

KAPETANOVIC et alii (1972) notaram que o AlB foi mais eficiente no tratamento de estacasde ameixeira, o que também foi constatado por ACHARYYA e DASH (1972), com pessegueiro;

CHAUHAN E REDDY (1974); BHANDARY E SHIVASHANKER (1974) e WALLY et alie (1981), todos mostram AlB como o melhor regulador, nos trabalhos desenvolvidós com ameixeira e cacaueiro.

\subsubsection{Juvenilidade}

Värias técnicas têm sido utilizadas com o objetivo de obtenção de melhoria no processo de enraizamento. En tre elas, o uso de juvenilidade que será comentadó a seguir.

Embora a vida dos tecidos pareça ser contínua, - ciclo de muitas espécies consiste em duas fases, nas quais, as características morfolögicas e fisiolōgicas, são diferen tes. Apōs a germinação da semente, a planta inicia uma fase de crescimento vegetativo muito vigorosa, durante oqual, a iniciaçãofloral e a floração não podem ser induzidas, mes mo quando as condições externas são favoräveis. Esse período denomina-se período juvenil (LEOPOLD, 1964; DUNBERG, 1977 e SALISBURY E ROSS, 1978). 
A juvenilidade, de acordo com LEOPOLD (1964), pode ser classificada em 2 tipos: a quantitativa e a qualitati va.

A juvenilidade quantitativa ocorre quando a planta está fisiologicamente apta para a floração, faltando so mente o estímulo externo, como por exemplo: a ocorrência de temperaturas favoráveis ao crescimento e desenvolvimento celuiar; estímulo provocado pelo fotoperiodismo ou a vernalizaçäo. E a juvenilidade qualitativa ocorre quando a planta não estä fisiologicamente apta para o florescimento.

SAX (1962); DOO REMBOS (1965); HARTMANN E KESTER (1975); ZIMMER MANN (1972); BIDWELL (1974) e SALISBURY e ROSS (1978) citam algumas das vantagens da fase juvenil. Em plan tas que se propagam facilmente por estacas, a idade da planta matriz tem pouca influência, porém, em plantas difíceis de enraizar, este pode ser um fator de muita importáncia. Em ge ral, tanto as estacas de ramos, como as de raiz tomadas de seedlings (em sua fase juvenil de. crescimento), enraizam com maior facilidade que aquelas tomadas de plantas mais velhas (em fase de crescimento adulto).

Outra vantagem è que o estado juvenil, possibi lita o desenvolvimento vegetativo da planta e a produção. de grande superfície foliar, necessäria e importante para captar a energia solar indispensävel para fotossíntese. Tambëm a produção de nutrientes que serão utilizados posteriormente no 
desenvolvimento dos frutos e de amplo sistema radicular, qual facilitarā a absorção de ägua e f́ós. do solo.

Em uma planta podem ser encontrados värios está dios entre a juvenilidade e a maturidade. Nas plantas, geral. mente a região basal é mais juvenil do que a região terminal. Diferenças estas, que segundo ALLSOPP (1965) e HARTMANN e KES TER (1975), se devem ao fato de que os meristemas mais próximos da base formaram-se em épocas mais proximas à germinação que os das regiōes terminais. Na propagaçäo vegetativa, utilizam-se em geral, estacas retiradas de ramos juvenis, capazes de formar raízes rapidamente.

GONÇALVES (1.982), baseando-se em extensa revi são, cita que durante o desenvolvimento ontogenético, os meris temas das plantas lenhosas podem sofrer mudanças gradual ou abrupta no potencial genético, do estädio juvenil para o adulto. Tais mudanças são frequentemente caracterizadas por diferenças fenotípicas.

As principais diferenças fenotípicas entre os estádios juvenil e adulto do desenvolvimento ontogenético das plantas lenhosas, são: hábito de crescimento, vigor, filota xia, forma e estrutura da folha, presença de espinhos, teor de leucoantocianinas, arquitetura da copa, anatomia e eficiência assimilatöria. 
A diferença morfológica entre plantas juvenil e adulta difere de uma espécie para outra, de acordo com DOOREN BOS $(1965)$.

- Os estudos mais completos no campo de desenvolvimento de caráter morfológico foram realizados em variaçõesna forma foliar, que são variações mais conspícuas do desenvolvimento, e possivel de expressão quantitativa.

Quanto à filotaxia (inserção das folhas sobre o caule), ZIMMERMANN (1972) afirma que pode ser diferente nas duas fases. Exemplificou o fato de que em muitas espécies de Eucaliptus, as folhas juvenis são opostas, enquanto as adultas são alternadas.

CHASE (1947) afirma que o häbito de crescimento é particularmente modificado, e que em muitas espëcies hä marcadas diferenças entre sua forma juvenil e adulta. Como exemplo, cita a Hera Inglesa, onde em șua forma juvenil o ramo é rasteiro, com folhas opostas palmadas ena forma adulta é um ar busto semi-ereto, com folhas inteiras, ovadas, dispostas alter nadamente ao redor dos ramos.

BLAIR et alii (1956) observaram a presença de espinhos em partes juvenis da planta de Citrus.

Entre as características fisiológicas se desta- 
cam: a habilidade de enraizamento e florescimento, a formaçäo de pigmentos e a queda das folhas.

$$
\text { ROMBERG (1944); MUCHADELL (1959) e ZIMMERMANN }
$$

(1972) afirmam que a caracteristica mais geral fisiológica da fase juvenil, é a inabilidade para produzir flores.

$$
\text { Com relação aos pigmentos, BOMBERG (1944) obser }
$$
va que em maçã, pecã e outras plantas as folhas juvenis produzem mais antocianinas que as adultas.

Quanto à "queda das folhas, MUCKADELL (1959) a. firma que algumas ärvores de follhas caducas, retêm suas folhas velhas e enrugadas durante o inverno nos ramos em fase juvenil, enquanto que ramos adultos derrubam suas follhas no outono.

As características anatoomicas e química das foIhas e caules, nas duas fases foramestudadas por alguns auto res.

De acordo com STREET e OPIK (1970), anatomica mente, as folhas adultas apresentam um grau mais alto de di ferenciação celular que as juvenis.

DOOREMBOS (1965) notou diferença entre folha juvenil e adulta; em värias ärvores florestais. Também observou diferença em Meregrana umbellata L. onde a folha adulta é caracterizada pela presença da hipoderme aquosa, ao passo que a folha juvenil é caracterizada pela epiderme papilar. 
Stoutemyer (1937), citado por HARTMANA e KESTER (1975) fez estudos em folhas juvenil e adulta, verificando a relação existente entre a composição química das mesmas e concluiu que havia maior conteüdo de fibras no periciclo do tecido adulto.

DOOREMBOS (1965) observa que o material juvenil tem menos amido, menor quantidade de açúcar, minerais e compos tos: nitrogenados, porém, mais celulose e lignina que o adul to.

FRITZCHE (1948) informa que o material adulto possui alta concentração de açūcares redutores e amido e menos nitrogénio e minerais que os tecidos juvenis.

BEAKBANE (1961) comparando brotações exibindo caracteristicas juvenis e adultas, ambas derivadas da amesma planta, de macieira, verificou que as brotaçóes basais juvenis são relativamente isentas de células escleróticas no floema primärio. Encontrou tambèm evidencias de afinidade entre anatomia e potencial de enraizamento. Verificou que existe correlação entre o graude esclerificação do floema primário e habilidade para enraizamento.

ALI e WESTWOOD (1968), trabalhando com estacas de Pynus callerjama; P. betulaefolia e P. communis, utilizando material juvenil e adulto, observaram que a quantidade to tal de carboidratos foi maior no primeiro ano, porém, esta diferença desapareceu no segundo ano. Observaram também que 
- tecido adulto contém mais $N$ solúvel e proteínas que o juve nil. Puderam observar que embora as estacasadultas desenvolvam mais calo, as juvenis enraízam melhor.

Levando em consideração que em estacas juvenis a percentagem de pegamento é geralmente superior, HARTMANN e KESTER (1975) informam que em espécies de difícil enraizamen to, pode-se fazer a indução de plantas adultas a estädio juvenil para facilitar o enraizamento das estacas. Utilizou-se pa ra isso os seguintes mëtodos: a) Indução de ramos adventicios em porções de raízes; b) Utilização do crescimento juvenil que se origina nos esferoblastos (crescimento em forma de verrugas que às vezes se encontram em troncos) e ramos que contêm tecidos meristemáticos e condutivos: c) Indução do crescimento dessas estruturas através da desbrota contínua ou poda severa da planta; d) Pulverização com giberelina onde se obtëm um estímulo substancial de crescimento e reversão de alguns ramos ao. estado juvenil; e) Manutençäo da juvenilidadé por condiçöes climäticas.

GONÇALVES (1982) cita também que vārios autores descreveram os métodos utilizados para a reversão à juvenilida de em meristemas apicais de plantas lenhosas e entre estes mëtodos estão: aplicação do ácido giberélico; neodiferenciação de gemas; poda drästica ou poda de gemas apicais; propagação vegetativa sucessiva; tratamento com raio-x; tratamento tërmico, frio ou calor. 
AWAD e CASTRO (1983) afirmam tambëm que a verna lização e o fotoperiodismo influenciam o periodo de juvenilida de.

Värios trabalhos foram realizados visando compa ração entre o comportamento do material juvenil e adulto, ob servando-se a percentagem de pegamento de estacas de materiais dos dois estágios.

BEAKBANE (1961) efetuando estudos comparati vos entre material juveril e adulto de várias espécies, além de realizar anăiises anatómicas em brotaçóes juvenis e adul tas, verificou que há màior capacidade de enraizamento em estacas de material juvenil.

ALi e WESTWOOD (1968) trabalhando com värias espécies de Pyrus: concluíram que apesar de no material adulto desenvolver mais calos, as juvenis apresentaram melhor en raizamento; isto foi observado também por BHANDARY e MUKHERJEE (1969) quando trabalharam com estacas de goiabeira.

Outros autores, trabalhando com outras espëcies, chegaram a essa mesma conclusão. Assim, STEPANOV e KUZIK (1973), trabalhando com cultivares de maçã M.9; M.3.; M.4 obti veram tambēm uma maior percentagem de pegamento, alëm de obterem maior rapidez no enraizamento de estacas juvenis em rela ção ao material adulto. O mesmo foi tambén observado por TARASENKO et alii (1973) com cultivares de ameixa e cereja. Verificou que o material juvenil enraizava 12 a 15 dias após 
o plantio e odulto, 20 a 22 dias após.

SMITH et alie (1974) trabalhando tambëm com estacas de de macieira, observaram en todos os casos, melhor enratizamento e sobre vivência das estacas juvenis, verificando percentagem de 20 a $30 \%$ para estacas no estädio adulto e $82 \%$ em estacas no estädio juvenill.

HALLIWELL e LARKBEY (1974) obtiveram 100\% de pegamento quando utilizaram estacas juvenis de Cupressus macro carpa. 0 mesmo foi observado por NASR e ABDEL-HAMID (1972) com estacas de citrus. PORLINGS e THERIOS (1976) com oliveira; KADMAN (1976)com abacateiro da raça mexicana; CURIR e SULIS(1982) com Eucalyptus sp.; e DAVIES et alie (1982) com ficus pumila. Obtiveram eles, sempre melhores percentagens de pegamento quando trabalharam com material juvenil.

Posteriormente, uma série de trabalhos surgiram evidenciando a influência da juvenilidade associada ao emprego das substâncias de crescimento, no enraizamento de estacas.

Värios autores, utilizando a associação destes fatores verificaram que houve maior percentagem de estacas en raizadas, aumento do nümero de raízes primärias, maior compri .. mento das raízes e tambēm aumento do nümero de raízes secundárias. Estes resultados podem ser verificados nos seguintes tra balthos: 
MENDILCIO GLU(1968) trabalhou com värias espé cies frutiferas entre elas: amendoeira, ameixeira,damasqueiro e ceréjel ra. Utilizando estacas de plantas com menos de quatro anos de ida de e de plantas de dez para vinte anos, verificou que em estacas juvenis, a percentagem de enraizamento fol melhor, eque o efeito do äcido indolbutírico na percentagem de enraizamento e crescimento dependem da concentração da auxina, da espécie e da idade da planta.

BHUJBAL (1972) trabalhando com estacas juvenis de goiabeira,utilizou värias concentrações de AlB desde 1000 até $4000 \mathrm{ppm}$ e o melhor resultado obtido foi de $86,6 \%$ de enraiza mento, quando utilizou tratamento a 3000 ppm.

CHATTERJEEE e MUKHERJEE (1980 e 1982) verifican do o comportamento de estacas júvenis de jaqueira, fizeram tratamentos com AlB nas concentrações de 5000 e 10000 ppm e 45 dias após o plantio, constataram boas percentagens de pegamento da ordem de 90 e $60 \%$, respectivamente, para tratamentos com 5000 e 10000 ppm.

ELAZZOUN l et alie (1979) realizando trabalhos com estacas de nogueira pecã,material juvenil e adulto, retiradas de plantas com idade variando entre 3 e 15 anos, tratadas em solu ção de AlB a $1000 \mathrm{ppr}$,verificaram que a maior percentagem de enrai zamento ocorreu, quando se utilizou material juvenil e trata mento com AlB.

Resultados semelhantes foram conseguidos 
SMITH e CHIU (1980) com estacas de nogueira pecã, em estä́dios juvenil e adulto. Verificaram que as que se encontravam em estädio juvenil, produziram mais raízes e enraizaram melhor quando trata das $\operatorname{com}$ A IB a $1 \%$.

$$
\text { FORDHAM (1982) utilizou estacas juvenis de }
$$

Eliotia racemosa, tratadas com AlB e tambëm obteve uma alta percentagem de enraizamento.

NYOMORA E MNZAVA (1982) trabalhando com estacas de macieira e pessegueiro,juvenis e adultas, verificaram que os melho res resultados foram obtidos quando utilizaram material juvenil e tratamento com AlB.

Para todos os trabalhos acima mencionados, os me lhores resultados foram obtidos com material juvenil, além de que os autores verificaram que $O$ AlB aumentou a capacidade de enraizamento de ambos os materiais juvenil e adulto. Porém tro balho realizado por PORLINGS e THERIOS (1976) com estacas de oliveira, mostraram que as estacas obtidas de material juvenil, apesar de mostrarem maior percentagem de enraizamento, este parâmetro não foi influenciado pela aplicação de AlB, aumentando somente o nümero de raízes por estacas. Porém, em estacas aduI tas, o AlB respondeu com aumento na percentagem de enraizamento e no nümero de rafizes por estaca. Os autores comentam que a per centagem de estacas juvenis foi alta sem a aplicaçãode auxina e que esta não fol namentada pelo tratamento com AlB, in 
dicando que talvez estas estacas tenham quantidade de auxina en dogena suficiente para o enraizamento. Isto não foi correto pa ra as adultas, nas quais a percentagem de enraizamento foi au mentada pela aplicaçäo de auxina (A|B).

\subsubsection{Estiolamento}

o uso de estiolamento, da aplicação de reguladores de crescimento ou o uso das duas tëcnicas juntas, tem apresentado bons resultados.

Segundo HARTMANN et alii (1981), estiolamento vem a ser o desenvolvimento de brotos, ramos, ou partes dos ramos em ausência de luz, causando um crescimento normalmente a longado, com coloraçäo amarela ou branca devido à ausência de clorofila. Não estão ainda bem definidos quais os efeitos prejudiciais da luz no enraizamento das estacas, podendo ser devido à fotoinativaçäou outros fatores naturais de enraizamento nos tecidos cortados do caule.

Os tipos de estiolamento encontrados na litera tura foram estiolamento dabase das estacas; estiolamento da planta inteira ou estiolamento de alguns ramos com material escuro.

Esta técnica, de acordo com HARTMANN et alii (1981) e SALISBURY e ROSS (1978) vem sendo utilizada com bastan te sucesso em estacas de espécies de difícil enraizamento, ci tando entre as frutiferas: o abacateiro, a mangueira, a macieira, a ce rejeira e outras. 
WEAVER (1976) e HARTMANN et alii (1981) afirmam que estacas desenvolvidas no escuro, enraizam mais facilmen te do que aquelas desenvolvidas em presença de luz.

$$
\text { HERMANN e HESS (1963) afirmam que estacas estio }
$$
ladas enrafzam melhor e contêm maior conteüdo de auxina e cofatores de enraizamento que as testemunhas ( $p$ lena luz).

Baseando-se neste principio, KAWASE (1964) observvou que durante o periodo de enraizamento de Salix daphonoides vill, a região estiolada da estaca teve melhor capacidade de retenção de auxina (A|A) que nas porções que se encon travam em presença de luz.

POLIKARPOVA (1972) trabalhando com ameixeira,ma cieira,e cerejeira,verificou que os ramos estiolados apresentavam grande reserva de nutrientes e alta quantidade de enzi mas estimuladoras de crescimento.

o efeito inibitório da luz foi pesquisado em muitos trabalhos, sendo obtidos resultados semelhantes aos de SHAPIRO (1958) o qual afirma que desenvolvimento de pré-forma ção de primórdios radiculares em älamo, foi inibido pela expo sição das estacas à luz.

A diminuição da concentração de regulador vegetal é também um método efetivo, indicando que a auxina está presente nos brotos estiolados em quantidade elevada. Isto é também sustentado pelo fato de que os ramos estiolados dão significativamente, maior percentagem de estacas enraizadas, 
mesmo sem tratamento com regulador vegetal quando comparados a ramos não estiolados (KAWASE, 1965).

Somente estudos limitados têm sido realizados em processos de enraizamento controlados pela luz. Hastes de ervilheira produzidas em presença de luz apresentammenor capacidade de absorção de ÁlA da solução do que aquelas crescidas no escuRO, GALSTON e BAKER (1953).

o início de formação de raízes em ramos não es tiolados de ervilheira foi inibido pela presença de luz, através do sistema fitocromo (FURYA e TORREY, 1964) ou pelo efeito de alta densidade de luz (TORREY, 1952).

A tēcnica de estiolamento tem alterado vārios componentes ou compostos das estacas, como GOWDA (1983) obser vou trabalhando com estacas estioladas e não estioladas de tamerindeiro. Concluiu que as estacas estioladas apresentaram maior percentagem de açücares totais, açūcares redutores e não reduto res e tambēm de nitrogēnio total e solüvel e de cofatores de enraizamento. Os niveis de amido, cofatores e inibidores de enraizamento foram maiores nas estacas não estioladas.

A tēcnica de estiolamento, vem sendo utilizada, visando aumento na percentagem de enraizamento das estacas Existem citações bastante antigas que falam sobre a utilização desta técnica como os trabalhos de knight e witt (1927), citados por WEAVER (1976) e o de GARDNER (1937), utilizando o es tiolamento para promover o enraizamento em estacas de macieira. 
WENT et alid (19.38) trataram estacas de ervilheira estioladas com AlA, obtendo maior percentagem de pegamento em relação à testemunha, sendo as melhores concentrações entre 20 e $100 \mathrm{~g} / 1$, pois concentrações mais altas inibiram o enraiza mento.

HERMANN e HESS (1963), trabalhando com estacas de Hibiscus, verificaram facilidade de enraizamento após o tratamento com àcido indolbutírico (AlB). Observaram tambēm que durante o experimento à base das estacas, apresentaram-se com coloração mais clara, devido ao meio de enraizamento, possivelmente estimulados pelos efeitos do estiolamento.

Uma sērie de trabalhos surgiram evidenciando a influência da associação do estiolamento e substâncias de crescimento. HARTMANN e KESTER (1975) afirmam que somente o uso de substâncias de crescimento não tem feito sucesso em algumas espécies; porém, a associação com o estiolamento melhorou o enraizamento de estacas de abacate da raça antiliana, assim como de outras espécies.

Em trabalhos realizados por outros autores, como FROLICH (1951)com abacateiro SINGH e TEAOTIA (1961) com mangueira; KAWASE (1965) com värias espécies; FROLICH (1972) com abacateiro e MOHAMEED e SORHAINDO (1984),com abacateiro, que também citam Frolich (1966), foram obtidos resultados semelhantes.

MUKHERJEE e BID (1965) observaram que utilizan do-se estiolamento somado à aplicação de reguladores vege 
tais obtiveram

alta percentagem de pegamento com

bom enraizamento das estacas. Para este trabalho os autores utilizaramestacas de mangueira cultivar Langra. As estacas antes de se rem retiradas das plantas, foram recobertas por tubos pretos de $16 \mathrm{~cm}$ de comprimento por $5 \mathrm{~cm}$ de diámetro, onde foi colocada vermiculita ümida durante 15 a 20 dias.

Ainda em relação a esta associaçäo de tēcnicas, com mangueira, BID e MUKHERJEE (1969) obtiveram com cultivar Lan gra, $100 \%$ de enraizamento quando brotaçöes estioladas foram tra tadas com concentraçöes de 10000 ppm de AlB e 5000 ppm de AiB + ANA $(1: 1)$. Com o cultivar Chansa, $98,66 \%$ de enraizamento foi ob tido em brotaçoes estioladas e tratadas com AlB + ANA $(1: 1)$.

MUKHERJEE et alii (1967), trabalharam com estacas de mangueira e abacateiro,utilizando além do estiolamento e trata mento com AlB (5000 ppm), estacas juvenis, obtendo-se maior per centagem de pegamento e melhor enraizamento. Resultados seme Ihantes foram obtidos por BASU et alii (1966), com mangueira, com $86 \%$ de pegamento.

Em relação à idade das estacas MUKHERJEE et alii (1967), observaram que o estiolamento aumentou a capacidade de enraizamento de estacas retiradas de de mangueira com 5 e 10 anos. A maior percentagem de enraizamento foi obtida em brotos estiolados com menor idade, apesar do nümero e compri mento das raízes terem sido maiores nas estacas não estioladas. BID e MUKHERJEE (1972) tambēm obtiveram resultados semelhantes com mangueira. 
Alguns autores como PROKHOROVA E POLIKARPOVA (1974) e BAKUN et alie (1982) estudaram a importância da época de realização do estiolamento para estacas de porta-enxertos de má cieira. Observaram que para os porta-enxertos MM 106; N-27B, PK-14 e Red leaved paradise, o melhor enraizamento ocorreu no verão havendo um declínio após essa estação, exceto para PK-14. BAKUN et alie (1982) utilizaram os porta-enxertos Budagoriskogo, Paradizka e 54-118, obtendo melhor percentagem de enraizamento no verão. REDDY et alii (1982) também obtiveram bors resultados, utilizando o estiolamento na mesma época.

Mais recentemente outros trabalhos vem sendo realizados, evidenciando a importancia do estiolamento para a maioria das espécies.

SCHMIDT (1982) utilizando o estiolamento no enraizamento de Tilia tomentosa, concluiu que houve melhore na capacidade de enraizamento e que esta capacidade foi conservada depois de quatro a seis semanas de subsequente exposição à iuz.

ROWELL (1982) para óbter mais informações, reali zou experimentos com Polygonum colinus, coryeus, Syringa e Elaeagnes spp, cultivares ou hibridos, comparando estiolamento e não estiolamento; concluiu que o estiolamento fol muito pro missor para Syringa.

Empregando o estiolamento em estacas folhosas de porta-enxertos de macieira M.9; HARRISON e MURRAY (1982) verificaram aumento de 11 para $78 \%$ na percentagem de enraizamento. 
Com o uso da aplicação conjunta de estiolamento e AIB, MCHARDY (1984) utilizou Hamamilis virginiana e Tilia enchlora, observando que ambas as espēcies produziram maior nümero de raízes quando suas estacas foram estioladas.

MOHAMEED e SORHAINDO (1984) utilizando estacas de abacateiro cultivares Poliock e Lula (guatemalense e hibrido do oeste da (ndia) e utilizando estiolamentoe também AlB obtive ram sucesso no enraizamento. Enfatizaram a importância de técnicas modernas como o uso do estiolamento, regulador vege tal e técnicas mistas para indução e aumento da percentagem de enraizamento das estacas.

outros trabalhos também foram realizados neste sentido. DHUA et alii (1983), realizando trabalhos com estacas de jaqueira, usaram estiolamento por 15 e 30 días e após a retirada das estacas, as mesmas foram tratadas com IBA a 3000 ppme àcido fenólico a 2000 ppm. Obtiveram percentagem de enraizamen to ao redor de $90 \%$ e pegamento em torno de $100 \%$.

CHATTERJEE e MULHERJEE (1982) fizeram trabalhos semelhantes com a jaqueira, competindo o estiolamento ou não e mais tratamento com IBA a 5000 e 10000 ppm. Obtiveram enraizamento de $100 \%$ quando empregaram o estiolamento e 5000 ppm de IBA.

Alēm dó uso das técnicas mistas de estiolamento e uso de reguladores vegetals; ainda existem alguns traba lhos nos quais os autores utilizam além destas duas técnicas, 
a juvenilidade como são os casos dos trabalhos que são citados a seguir.

LANGARAJAPPA (1982) trabalhando com afporquia em jaqueira e utilizando as técnicas de estiolamento, juvenilidade e tratamento com IBA + NAA, verificou que houve maiores per centagens de enraizamento, de comprimento das raízes e de pega menta, quando foram utilizadas conjuntamente as técnicas de es tiolamento e a aplicação do regulador vegetal, do que quando foram utilizados cada um desses tratamentos em separado. Também observou que onde se utilizou material juvenil, houve uma diferença de 30 dias de antecedencia no enraizamento. Resulta dos semelhantes foram obtidos também por THAKURTA e DUTA(1941), com mangueira. 
46.

3. MATERIAL E METODOS

\subsection{Condições Locais}

0 presente trabaliho foi conduzido na ärea experimental do Setor de Horticultura, do Departamento de Agricultura e Horticultura da Escola Superior de Agricultura "Luiz de Queiroz", da Universidade de São Paulo, em Piracicaba, São Pau 1o, Brasil.

Foi realizado uma sërie de experimentos, com es tacas de ramos herbáceos e com estacas de raízes, em ripado cujas temperaturas mëdias se encontram na figura 7 do apêndice, variando de $19,21^{\circ} \mathrm{C}$ para as minimas e $31,78^{\circ} \mathrm{C}$, para a máximas. E em canteiros de alvenaria com temperatura média da mínima de $15,10^{\circ} \mathrm{C}$ e média da mäxima de $29,46^{\circ} \mathrm{C}$.

Segundo SETEZER (1966), o clima da região, de acordo com a classificação de Köppen, é do tipo CWa, ou seja, mesotérmico úmido tropical, com inverno seco, apresentando pre 
cipitação mëdia anual de $1200 \mathrm{~mm}$. A latitude é de $22^{\circ} 42^{\prime} 09^{\prime \prime} 5$ e a altitude è de $540 \mathrm{~m}$.

Os dados climáticos referentes as temperaturas e precipitação para os anos de 1984 e 1985 , são apresentados no apêndice ( $f$ iguras 8 e 9 ).

\subsection{Experimento 1 - Regeneração de ameixeira atravēs de estacas de ramos herbáceos}

A espécie utilizada para esse experimento foi a ameixeira (Prunus salicina L.), cujos cultivares envolvidos foram Carmesin, Gema de Ouro, Grancuore, Golden Talismã, Kelsey Paulista e Rosa Paulista. Foram utilizadas estacas de ramos her báceos, obtidas de plantas do pomar do Setor de Horticultura da ESALQ, com 7 anos de idade, enxertadas sobre porta-enxerto de pessegueiro.

\subsubsection{Práticas Culturais Realizadas}

Inicialmente no dia $18 / 08 / 85$, foram efetuadas podas drásticas nos ramos das plantas, época esta em que as mes mas se encontravam com a maioria das gemas em repouso vegetati- vo e algumas com início de brotação. Esta poda foi realizada com a finalidade de forçar a planta a emitir brotação vigorosa e uniforme. Para cada cultivar foram utilizadas duas plantas. Após a poda, foram realizadas capinas e contro les fitossanitários, estes iniciados logo após a emergência das bro- 
tações e repetidos a cada quinze dias.

\subsubsection{Retirada e Preparo das Estacas}

As estacas foram retiradas das plantas no dia $21 / 10 / 85$, isto é, setenta dias após a realização da poda. Foi retirado maior numero de estacas para permitir posterior sele६̧ão.

os ramos obtidos com ajuda de tesoura de poda foram retirados das plantas e colocados em sacos plásticos pre viamente umedecidos e mantidos à sombra. Posteriormente os ra mos foram levados para o laboratório, onde as estacas foram se lecionadas e preparadas, deixando-se apenas de 6 a 8 folhaspor estaca. Foram tomados cuidados relativos à manutençäo da umidade junto às estacas.

3.2.3. Local de Instalação do Experimento

0 experimento foi instalado em ripado, com cobertura de sombrite com retenção de $50 \%$ de luminosi dade. As paredes laterais eran de plästico transparente. 0 sistema de irrigação utilizado foi o de nebulização intermiten te.

0 experimento foi instalado no dia $21 / 10 / 85$, is to é, setenta dias após a realização da poda. As estacas fo- 
ram colocadas em substrato constituido de vermiculita fina.Foram fixadas pelo enterrio de cerca de $4 \mathrm{~cm}$ da haste.

o susbstrato foi colocado em caixas de madeira com dimensões de $0,70 \times 0,50 \times 0,10 \mathrm{~m}$, respectivamente, para comprimento, largura e altura.

\subsubsection{Tratamento das Estacas}

Os tratamentos nos seis cultivares foram realiza dos com a aplicação de regulador vegetal. Foi utilizado o àcido indolbutírico (A|B), cuja solução estoque foi previamente diluída a $50 \%$ de etanol. Dois centímetros da base das estacas foram imersos durante 5 segundos na solução. 0 tratanento con trole constou da imersão das estacas em àgua destilada.

Os tratamentos utilizados foram:

$C_{1} T_{0}$ - cultivar Carmesin, com concentração de 0 ppm de AlB $C_{1} T_{1}$ - cultivar carmesin, com concentraçäo de 2000 ppm de AlB $C_{1} T_{2}$ - cultivar carmesin, com concentração de 4000 ppm de AlB $C_{2} T_{0}$ - cultivar Gema de 0uro, com concentração de 0 ppm de AlB $C_{2} T_{1}$ - cultivar Gema de ouro, com concentração de 2000 ppm de AlB $C_{2} T_{2}$ - cultivar Gema de 0uro, com concentração de 4000 ppm de AlB $C_{3} T_{0}$ - cultivar Grancuore, com concentração de 0 ppm de AlB $C_{3} T_{1}$ - cultivar Grancuore, com concentração de 2000 ppm de AlB $C_{3} T_{2}$ - cultivar Grancuore, com concentraçäo de 4000 ppm de AlB 
$C_{4}{ }^{\top} 0$ - cultivar Golden Talismã, com concentração de 0 ppm de AlB

$C_{4} T_{1}$ - cultivar Golden Talismä, com concentração de 2000 ppm de AlB

$\mathrm{C}_{4} \mathrm{~T}_{2}$ - cultivar Golden Talismä, com concentração de 4000 ppm de AlB

$C_{5} T_{0}$ - cultivar Rosa Paulista, com concentração de 0 ppm de AlB

$C_{5} T_{1}$ - cultivar Rosa Paulista, com concentração de 2000 ppm de AlB

$C_{5} T_{2}$ - cultivar Rosa Paulista, com concentração de 4000 ppm de AlB

$C_{6} T_{0}$ - cultivar Kelsey Paulista, com concentração de 0 ppm de AlB

$C_{6} T_{1}$ - cultivar Kelsey Paulista, com concentração de 2000 ppm de AlB $C_{6} T_{2}$ - cultivar Kelsey Paulista, com concentração de 4000 ppm de AlB

3.2.5. Delineamento Experimental

0 experimento foi conduzido em blocos ao acaso, com 18 tratamentos e 3 repetições (blocos), tendo-se mantido 10 estacas por parcela.

Foi feita a anälise estatística através do es quema fatorial em blocos ao acaso, sendo que os dados do parámetro avaliados foram transformados em $\sqrt{x+0,5}$. Para comparação das médias utilizou-se o teste de Tukey.

3.2.6. Constatação do Enraizamento das Estacas

Para avaliação do enraizamento, as estacas foram retiradas do substrato nos dias 08 e $09 / 01 / 86$, isto $\vec{e}$, oi tenta dias após a instalação das mesmas. 
Esta operação foi realizada com o auxilio de um chucho, com cuidado para evitar injürias nas raízes, as quais foram posteriormente lavadas e examinadas.

O efeito dos tratamentos foi avaliado pelo nüme ro de estacas enraizadas, ointenta dias após a sua instalação.

3.3. Experimento 2 - Regeneração de nespereira através de estacas de ramos herbäceos

A especie envolvida neste experimento foi a nes pereira (Eriobotrya japonica Lindley). Foram utilizadas estacas de ramos herbāceos, dos cultivares Mizuho e Precoce de lta quera, obtidas de plantas com 6 anos de idade, existentes no Setor de Horticultura da ESALQ.

\subsubsection{Präticas Culturais Realizadas}

Inicialmente foram feitas no dia $15 / 08 / 85$, podas drästicas nos ramos das plantas, que iriam fornecer as estacas. Para cada cultivar foram utilizadas duas plantas.

$$
\text { Apōs as podas foram realizadas capinas e contro }
$$

les fitossanitärios. 
Cinquenta e quatro dias após a realização da po da, a qual foi feita no dia $15 / 08 / 85$, efetuou-se o estiolamento dos ramos. Esta operação constituiu no envolvimentode $5 \mathrm{~cm}$ da base dos ramos, com plästico escuro, fixado através de fi tilho plästico.

3.3.2. Retirada e Preparo das Estacas

As estacas foram colhidas no dia $31 / 10 / 85$, vinte e três dias após a realização da prätica do estiolamento.

A operação de retirada e preparo das estacas foi realizada da mesma maneira descrita no experimento 1.

Neste experimento foram deixadas de 3 a 5 fo lhas por estaca. As folhas de maiores dimensões foram corta das ao meio para evitar maior perda por transpiração.

3.3.3. Local de Instalação do Experimento

Este experimento foi instalado nas mesmas condi ções do experimento 1.

A instalação foi realizada no dia $31 / 10 / 85$, setenta e sete dias após a poda. 
3.3.4. Tratamento das Estacas

As variáveis neste experimento foram:

a) Dois cultivares ( $C_{1}=$ Mizuho e $C_{2}$ Precoce de Itaquera)

b) Duas concentrações de AlB (2000 e $4000 \mathrm{ppm})$

c) Uso da Prātica ou não do Estiolamento

As estacas foram tratadas com äcido indolbutír co (AlB)por 5 segundos em soluções de 2000 e 4000 ppm. Fez-se a imersão de cerca de 2 a $3 \mathrm{~cm}$ da base das estacas. 0 tratamento controle constou da imersão da base das estacas por 5 se gundos em àgua destilada, tendo sido realizados os seguin tes tratamentos:

$C_{1} E_{0} D_{0}$ - cultivar Mizüho, sem estiolamento, 0 ppm de $A \mid B$ $C_{1} E_{0} D_{1}$ - cultivar Mizuho, sem estiolamento, $2000 \mathrm{ppm}$ de AlB $C_{1} E_{0} D_{2}$ - cultivar Mizuho, sem estiolamento, $4000 \mathrm{ppm}$ de AlB $C_{1} E_{1} D_{0}$ - cultivar Mizuho, com estiolamento, 0 ppm de AlB $C_{1} E_{1} D_{1}$ - cultivar Mizuho, com estiolamento, $2000 \mathrm{ppm}$ de AlB $C_{1} E_{1} D_{2}$ - cultivar Mizuho, com estiolamento, 4000 ppm de AlB - $C_{2} E_{0} D_{0}$ - cultivar Precoce de Itaquera, sem estiolamento, 0 ppm de AlB $C_{2} E_{0} D_{1}$ - cultivar Precoce de 1 taquera, sem estiolamento, 2000 ppm de AlB $C_{2} E_{0} D_{2}$ - cultivar Precoce de 1 taquera, sem estiolamento, 4000 ppm de AlB $C_{2} E_{1} D_{0}$ - cultivar Precoce de Itaquera, com estiolamento, 0 ppm de AlB 
$C_{2} E_{1} D_{1}$ - cultivar Precoce de Itaquera, com estiolamento, 2000 ppm de AlB $\mathrm{C}_{2} \mathrm{E}_{1} \mathrm{D}_{2}$ - cultivar Precoce de Itaquera, com estiolamento, $4000 \mathrm{ppm}$ de $\mathrm{AlB}$

3.3.5. Delineamento Experimental

0 experimento foi conduzido em blocos ao acaso, com 12 tratamentos, 3 repetições (blocos), mantendo-se 10 esta cas por parcela.

A anālise estatística foi feita atravēs do es quema fatorial em blocos ao acaso, sendo que os dados do parâmetro avaliado, foram transformados em $\sqrt{x+0,5}$ Para comparação das médias utilizou-se o teste de Tukey.

3.3.6. Constatação do Enraizamento das Estacas

Para avaliação do experimento, as estacas fo- ram retiradas do substrato no dia $04 / 02 / 86$, noventa e cinco días apōs a instalação das mesmas.

Esta operação foi realizada com o auxílio de um chucho, com cuidado para evitar injürias nas raízes. Pos teriormente estas foram lavadas e obtidos os dados de enraizamento das es tacas.

o efeito dos tratamentos: foi avaliado pelo enraizamento das estacas. 


\subsection{Experimento 3 - Regeneraçäo de pitangueira atravēs de} estacas de ramos herbáceos

Estacas de ramoś herbāceos de pitangueiräEugênia uniflora Lindleyl foram utilizadas para a realização desse experimento. Foram empregadas estacas de materiais juvenil e adulto, obti das de plantas existentes no Setor de Horticultura da ESALQ.

\subsubsection{Präticas Culturais Realizadas}

Inicialmente foram realizadas podas nas plantas que iriam fornecer as estacas. Para cada tipo de estaca. foram utilizadas duas plantas. Posteriormentefez-se controle fitossanitärio e controle de plantas daninhas.

Os tecidos adultos foram obtidos a partir da parte apical de pés. francos com cerca de 45 anos de idade. 0 material juvenil, a partir de seedlings de 2 anos de idade. Em ambos os casos as plantas foram submetidas a podas drästicas realizadas no dia $10 / 08 / 85$.

\subsubsection{Retirada e Preparo das Estacas}

As estacas foram retiradas e preparadas, da me $\underline{s}$ ma maneira descrita no experimento 1. Neste experimento foram deixadas de 6 a 8 folhas por estaca. 
A retirada das estacas das plantas foi realizada no dia $29 / 10 / 85$, setenta e sete dias após a realização da poda (como citado no experimento 1 ).

\subsubsection{Local delnstalação do Experimento}

Este experimento foi instalado nas mesmas condi ções jà descritas no experimento 1 , no mesmo dia em que as estacas foram retiradas.

3.4.4. Tratamento das Estacas

As estacas foram tratadas com $A \mid B$ em soluçöes de 1000,2000 e $4000 \mathrm{ppm}$. Para o tratamento das mesmas, fez -se a imersão de cerca de 2 a $3 \mathrm{~cm}$ da base das estacas. As es tacas controle foram imersas em ägua destilada por 5 segundos, resultando os seguintes tratamentos:

$M_{1} T_{0}$ - Material juvenil, 0 ppm de $A / B$ ou $\mathrm{H}_{2} \mathrm{O}$ destilada

$M_{1} T_{1}$ - Material juvenil, 1000 pem de AlB

$M_{1} T_{2}$ - Material juvenil, 2000 ppm de AlB

$M_{1} T_{3}$ - Material juvenil, 4000 ppm de AlB

$M_{2} T_{0}$ - Material adulto, 0 ppm de AlB

$\mathrm{M}_{2} \mathrm{~T}_{1}$ - Material adulto, $1000 \mathrm{ppm}$ de $\mathrm{AlB}$

$\mathrm{M}_{2} \mathrm{~T}_{2}$ - Material adulto, $2000 \mathrm{ppm}$ de AlB 
$M_{2} T_{3}$ - Material adulto, 4000 ppm de AlB

3.4.5. Delineamento Experimental

Este experimento foi conduzido em blocos ao aca so, com 8 tratamentos, 4 repetições (blocos), utilizando-se 10 estacas por parcela.

Efetuou-se anälise estatística, atravès do es quema fatorial em blocos ao acaso. Os dados do parámetro avaliado, fo ram transformados em $\sqrt{x+0,5}$. Para comparação das mëdias ut lizou-se o teste de rukey.

3.4.6. Constatação do enraizamento

Para a avaliaçäo do enraizamento, as estacas foram retiradas e analisadas pelo mesmo processo descrito no experimento 1 .

Efetuou-se a retirada no dia $02 / 01 / 86$, isto é, sessenta e cinco dias apōs a instalação das estacas.

0 efeito dos tratamentos foi avaliado pelo en raizamento das estacas. 
3.5. Experimento 4 - Regerieração de nogueira pecã através de estacas de raízes

A espécie objetodeste experimento fol a nogueira pecã (Carya illinoensis koch). Foram utilizadas estacas de raízes de plantas adultas com 20 anos e de plantas juvenis com 3 anos de idade, do cultivar Piracicamirim, a partir de plantas exis tentes no Setor de Horticultura da ESALQ.

\subsubsection{Retirada e Preparo das Estacas}

As estacas de material juvenil foram obtidas no dia $03 / 08 / 04$, através de arranquio de seedlings.

O material adulto foi obtido no dia $06 / 08 / 84$. Para retirada destas estacas foi realizada primeiramente uma aração de $0,50 \mathrm{~m}$ de profundidade, e os segmentos das raízes fo ram coletados no solo arado.

As estacas, foram colocadas em sacos plästi cos umedecidos e mantidos à sombra. A seguir, em laboratório, foram separadas pelo diâmetro em grupos de:

a) Diâmetro entre 0,5 a $1,0 \mathrm{~cm}$

b) Diâmetro entre 1,0 a $1,5 \mathrm{~cm}$

c) Diâmetro entre 1,5 a $2,0 \mathrm{~cm}$

o comprimento foi padronizado em 15 a $17 \mathrm{~cm}$. 
3.5.2. Local de Instalação do Experimento

Este experimento foi instalado em canteiros de alvenaria, com dimensões de $20,0 \times 1,50 \mathrm{~m}$ de comprimento e lar gura, respectivamente, preenchido com terra areno-argilosa, nas proporções de $(2: 1)$.

Após a terrater sido preparada, foi realizada a desinfecção da mesma, utilizou-se o produto fumigante BLENCO: na dosagem de $50 \mathrm{~cm}^{3} / \mathrm{m}^{2}$.

Completado o preparo do solo e decorridos

dias, as estacas foram fincadas em espaçamentos de $0,30 \mathrm{~cm}$ entre linhas e $0,15 \mathrm{~m}$ entre as estacas.

os tratos culturais realizados posteriormentefo ram: mondas; irrigações em dias alternados e escarificações en tre as linhas para evitar compactação da terra.

3.5.3. Tratamentos Utilizados e Plantio das Estacas

Os tratamentos utilizados foram os seguintes:

$M_{1} D_{1}$ - Material Juvenil, diâmetro de 0,5 a $1,0 \mathrm{~cm}$

- $M_{1} D_{2}$ - Material Juvenil, diâmetro de 1,0 a $1,5 \mathrm{~cm}$

$M_{1} D_{3}$ - Material Juvenil, diàmetro de 1,5 a $2,0 \mathrm{~cm}$

$M_{2} D_{1}$ - Material Adulto, diámetro de 0,5 a $1,0 \mathrm{~cm}$

$M_{2} D_{2}$ - Material Adulto, diâmetro de 1,0 a $1,5 \mathrm{~cm}$ 
$\mathrm{M}_{2} \mathrm{O}_{3}$ - Material Adulto, diâmetro de 1,5 a $2,0 \mathrm{~cm}$

o plantio foi realizado no dia $07 / 08 / 84$. As es tacas foram enterradas, ficando somente pequena parte exposta na superfície do solo, sempre tomando-se cuidado com a polaridade das estacas.

3.5.4. Delineamento Experimental

o experimento foi conduzido em blocos ao acaso, com 8 tratamentos, 4 repetiçöes (blocos), com 10 estacas por parcela.

Fez-se a anàlise estatística através do esquema fatorial em blocos ao acaso, sendo que os dados do parâmetro avalia do foram transformados em $\sqrt{x+0,5}$. Para comparação das mẽdias utilizou-se o teste de Tukey.

3.5.5. Constatação do Enraizamento das Estacas

Numa primeira fase de avaliação do comportamento das estacas, foram feitas leituras semanais onde eram ava liados os enfolhamentos das estacas. Essas avaliações foram iniciadas em $05 / 10 / 84$ e completadas em $06 / 06 / 85$, quando as estacas foram arrancadas para avaliação do sistema radicular. 
o efeito dos tratamentos foi avaliado pelo enrai mento das estacas.

3.6. Experimento 5 - Regeneração de pitangueira através de estacas de raizes

A espécie envolvida neste experimento foi a pitangueira (Eugenia uniflora Lindley). Foram utilizadas iestacas de raízes, obtidas de seedlings de 2 anos de idade para mate: rial juvenil e seedlings de 45 anos de idade para material adul to, existentes no Setor de Horticultura da ESALQ.

\subsubsection{Retirada e Preparo das Estacas}

As estacas de material juvenil e adulto foram obtidas por processos diferentes, como descritos no experimento 4. Efetuou-se a retirada das estacas nos dias 10 e $11 / 07 / 84$, respectivamente, para material juvenil e adulto.

o preparo das estacas foi realizado como citado no experimento 4 .

$$
\text { As estacas foram colocadas em sacos plásticos }
$$

umedecidos e mantidos à sombra. A seguir, em laboratório, fo.ram separadas pelo diámetro e pelo tipo de material, em gru - 
pos de:

Material Juvenil
a) Diâmetro menor que $0,5 \mathrm{~cm}$
b) Diãmetro maior que $0,5 \mathrm{~cm}$

Material Adulto

a) Diâmetro menor que $1,0 \mathrm{~cm}$

b) Diâmetro maior que $1,0 \mathrm{~cm}$

3.6.2. Local de Instalação do Experimento

o experimento foi instalado em canteiros iguais aos descritos no experimento 4 .

Neste experimento foram utilizados diferentes ti pos de substrato. Para isso a terra do canteiro (mesmo utiliza do no experimento 4) foi retirado, abrindo-se $15 \mathrm{~cm}$ de comprimento por $15 \mathrm{~cm}$ de largura e $15 \mathrm{~cm}$ de profundidade, espaço em que era preenchido como substrato desejado. Dessa forma for am dispostos os diferentes substratos no canteiro, obedecendo o esquema estatístico.

Os substratos utilizados foram: areia; terra e vermiculita fina. 
3.6.3. Tratamentos Utilizados e Plantio das Estacas

Para o desenvolvimento desse experimento foram utili zados 2 materiais (juvenil e adulto); 3 substratos (areia, terra e vermiculita) e 2 diàmetros: a) para material juvenil onde $D_{1}=$ = menor que $0,5, \mathrm{~cm}, D_{2}=$ maior que $0,5 \mathrm{~cm}$; b) para material adul to, diâmetro $D_{1}=$ menor que $1,0 \mathrm{~cm}, D_{2}=$ maior que $1,0 \mathrm{~cm}$.

Os tratamentos utilizados foram, respectivamen -

te :

$M_{1} S_{1} D_{1}$ - Material Juvenil, substrato areia

$M_{1} S_{1} D_{2}$ - Material Juvenil, substrato areia

$M_{1} S_{2} D_{1}$ - Material Juvenil, substrato terra

$M_{1} S_{2} D_{2}$ - Material Juvenil, substrato terpa

$M_{1} S_{3} D_{1}$ - Material Juvenil, Substrato vermiculita

$\mathrm{M}_{1} \mathrm{~S}_{3} \mathrm{D}_{2}$ - Material Juvenil, substrato vermiculita

$M_{2} S_{1} D_{1}$ - Material Adulto, substrato areia

$M_{2} S_{1} D_{2}$ - Material Adulto, substrato areia

$M_{2} S_{2} D_{1}$ - Material Adulto, substrato terra

$M_{2} \mathrm{~S}_{2} \mathrm{D}_{2}$ - Material Adulto, substrato terra

$\mathrm{M}_{2} \mathrm{~S}_{3} \mathrm{D}_{1}$ - Material Adulto, substrato vermiculita

$M_{2} S_{3} D_{2}$ - Material Adulto, substrato vermiculita

A instalação do experimento foi realizada

no 
dia $12 / 07 / 85$, tomando cuidado com a polaridade das estacas.

3.6.4. Delineamento Experimental

o experimento foi conduzido em blocos ao acaso, com 12 tratamentos, 2 repetições $(2$ blocos $)$, com 10 estacas por parcela.

Fez-se a anälise estatística atravēs do esquema fatorial em blocos ao acaso, sendo que os dados do parâmetro avaliado foram transformados em $\sqrt{x+0,5}$. Para comparação das médias utilizou-se o teste de Tuckey.

3.6.5. Constatação do Enraizamento

Para avaliação dos comportamentos das estacas foram feitas leituras semanais, onde eram avaliados os enfolha mentos das estacas. Essas avaliações foram iniciadas em $09 /$ $101 / 85$ e completadas em $27 / 06 / 85$.

Foram anotados os nümeros de estacas que enrai zaram e o número de brotações por estaca.

0 efeito dos tratamentos foi ayaliado pelo enrai mento das estacas. 
4. RESULTADOS

4.1. Experimento 1. Regeneração de ameixeira através de. estacas de ramos herbàceos.

Foram estudadas as relações entre os diferentes cultivares e värias concentrações de àcído indolbutírico (A/B), no enraizamento das estacas de ramos herbáceos de ameixeira. Os resulta dos estão na tabela 14, no apêndice.

Através da anälise da variância (tabela 1) verificou-se que ocorreu diferença significativa para cultivares, näo revelando diferenças para as diferentes concentrações de AIB, as im como para a interação cultivares $x$ concentrações.

0 teste das médias revelou que ocorreram diferenças entre os cultivares. Os cultivares Gema deOuro, Carmes in e Golden Taísmã, não dife riram entre si, assim como Golden Talismä, Grancuore e Kelsey Pau lista não diferiram entre eles e Grancuore, Kelsey Paulista e Rosa Paulista, tambēm não diferiram entre si. Porëm, Gema de ouro e carnesin diferiram de Grancuore, Kelsey Paulista e Rosa Paulista (tabela 2). 
observou-se ainda pela tabela 2 , as seguintes percentagens de enraizamento: Gema de 0uro 88,74\%; Carmesin $85,80 \%$; Golden Talismá $79,24 \%$; Grancuore $58,30 \%$; Kelsey Paulis ta $58,18 \%$ e Rosa Paulista $44,02 \%$.

0 desdobramento da anălise estatística mostrou significancia entre os cultivares dentro dos tratamentos con :trole e menor concentração, o mesmo não ocorrendo para a maior concentração. Assim, para o tratamento controle, os cultivan res Gema de Ouro, Carmesin e Golden Talismã näo diferiram en -tre si, porëm diferiram dos cultivares Rosa Paulista, Grancuore e Kelsey Paulista.Na concentração de $2000 \mathrm{ppm}$ de AlB, os cultivares Gema de Ouro, Carmesin, Golden Talismã. Kelsey Paulista e Grancuore não diferiram entre si, assim como Grancuore e Rosa Paulista não diferiram entre si, porém Rosa Paulista di feriu de Gema de Ouro, Carmesin, Golden Talismã, Kelsey Paulis ta e Grancuore. Para $4000 \mathrm{ppm}$, os seis cultivares não diferiram entresi (tabela 3 e figura 1$)$.

0 enraizamento das estacas em funçăo da concentração de AIB, ainda foi melhor observado nos cultivares Grancuore e Kelsey Paulista, para os quais foram encontradas, respectivamente, relações linear e quadrätica. Através da figu ra 2, verificou-se que quando aumentou a concentração de $A / B$, o enraizamento das estacas do cultivar Grancuore também aumentou. 
Pela figura 3 , observou-se que para o cultivar Kelsey Paulista, a concentração de 2000 ppm de AlB, apresentou melhor resultado, apresentando uma diminuíção no enraizamento, quando utilizou-se concentração de 4000 ppm. Notou-se ainda pela figura 3, que para a concentração de 4000 ppm, a percenta gem de enraizamento foi menor que para o tratamento controle.

As equaçöes de regressão que melhor se ajusta ram para o enraizamento das estacas em função da concentração de $A / B$, para os cultivares Grancuore e Kelsey Paulista, foram respectivamente:

$$
\begin{aligned}
& Y=2,129730+0,1931330 \cdot x \\
& Y=2,083990+0.6393026 \cdot x-0,12736263 \cdot x^{2}
\end{aligned}
$$

Suas representaçöes grâficas se encontram.

nas

figuras 2 e 3 . 
TABELA 1. Anälise da variancia do enraizamento das estacas de ramos herbäceos de ameixeira em diferentes cultivares e diferentes concentrações de AlB.

Causas da variação

GL

QM

$\begin{array}{lcl}\text { Blocos } & 2 & 0,2142716 \\ \text { Cultivar } & 5 & 1,0234210^{* *} \\ \text { Concentração } & 2 & 0,2065793 \mathrm{n} . \mathrm{s} . \\ \text { Cult. x conc. } & 10 & 0,1825002 \mathrm{n} . \mathrm{s} . \\ \text { Residuo } & 34^{*} & 0,0894454\end{array}$

Total

\section{3}

c.v. $(\%)=11,070$

**significativo ao nivel de $1 \%$ de probabilidade. n.s. = não significativo

TABELA 2. Mëdias de enraizamento de estacas de ramos herbäceos de amei xeira, nos diferentes cultivares.

Cultivar

Gema de ouro

Carmesin

Golden Talismã

Grancuore

Kelsey Paulista.

Rosa Paulista
Médias Transformadas.

Mëdias Originais

8,874482 a

8,579910 a

$7,923976 a b$

5,830228 bc

5,817737 bc

$4,401374 \quad \mathrm{c}$

Médias seguidas de letras distintas diferem entre si ao ní vel de $5 \%$ de probabilidade, pelo teste de Tukey. 
TABELA 3. Nümero mëdio de estacas de ramos herbäceos enraizadas dos diferentes cultivares de ameixeira influenciados pelas diferentes concentraçöes de AlB.

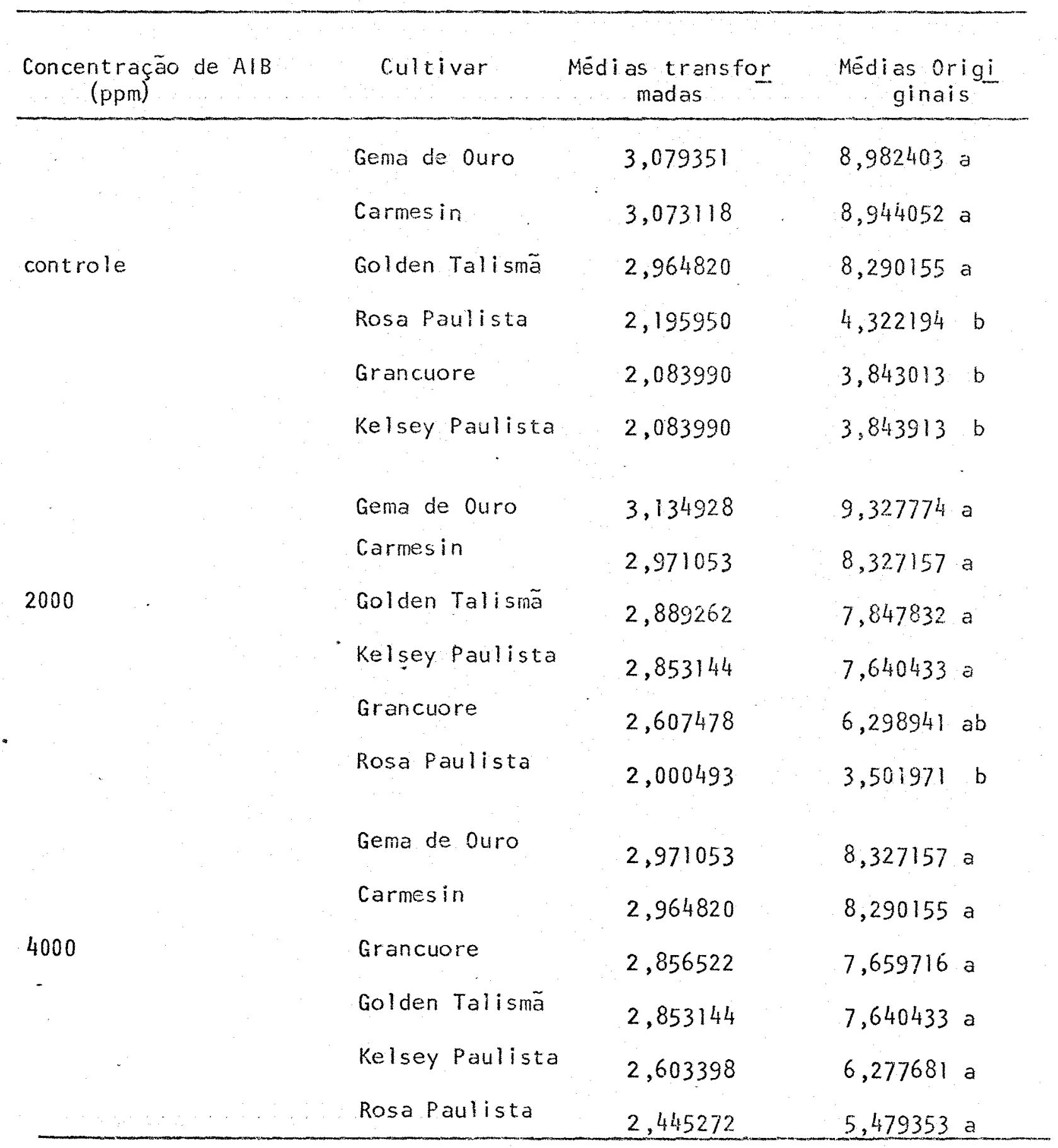

Médias seguidas por letras distintas diferem entre si ao nivel de $5 \%$ de probabilidade, pelo teste de Tukey. 


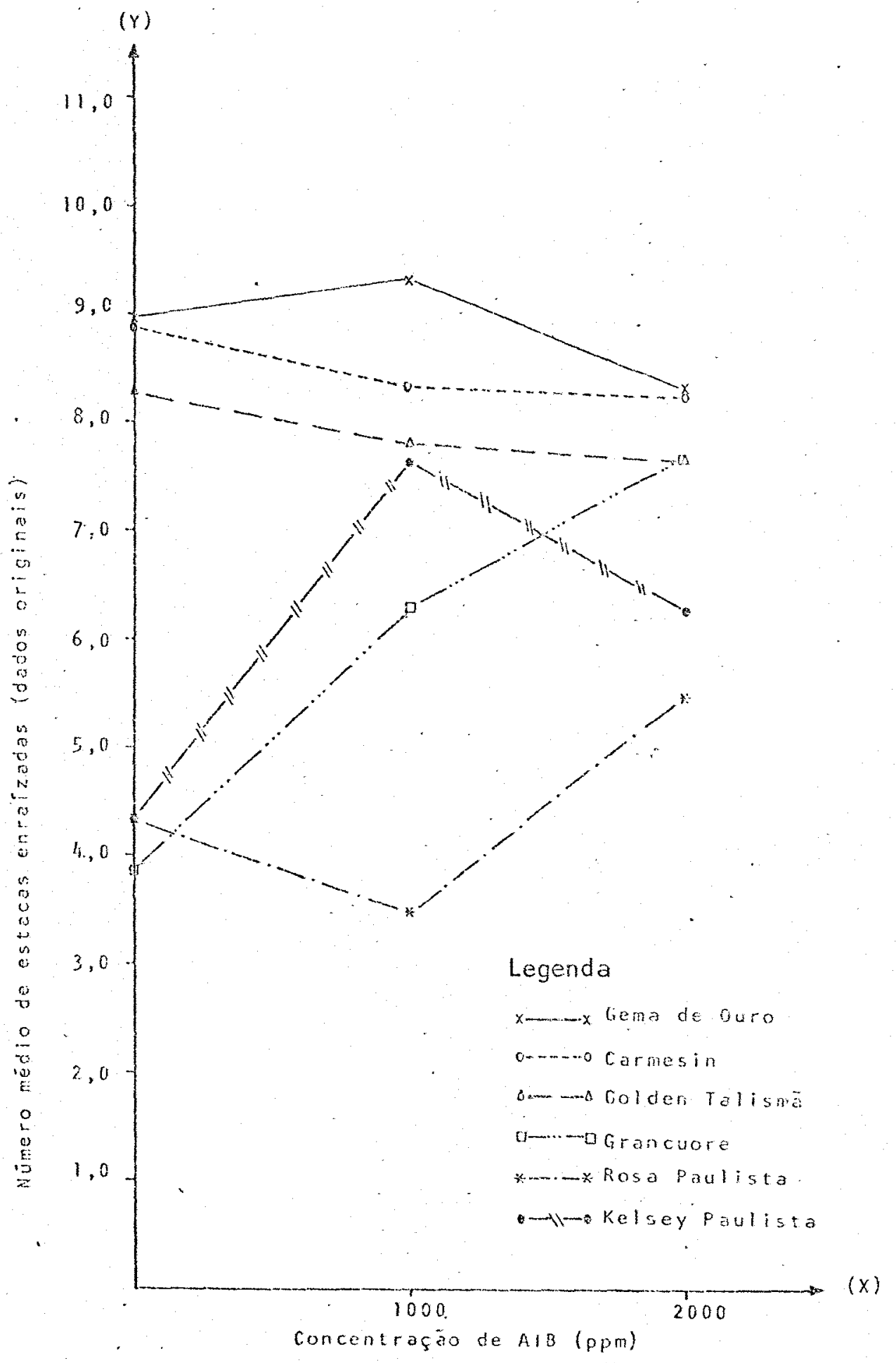

Figura 1.Nümeros médios de estacas de ramosherbáceos enraizadas de seis cultivares de ameixeira e diferentes concentraçōes de AlB. 


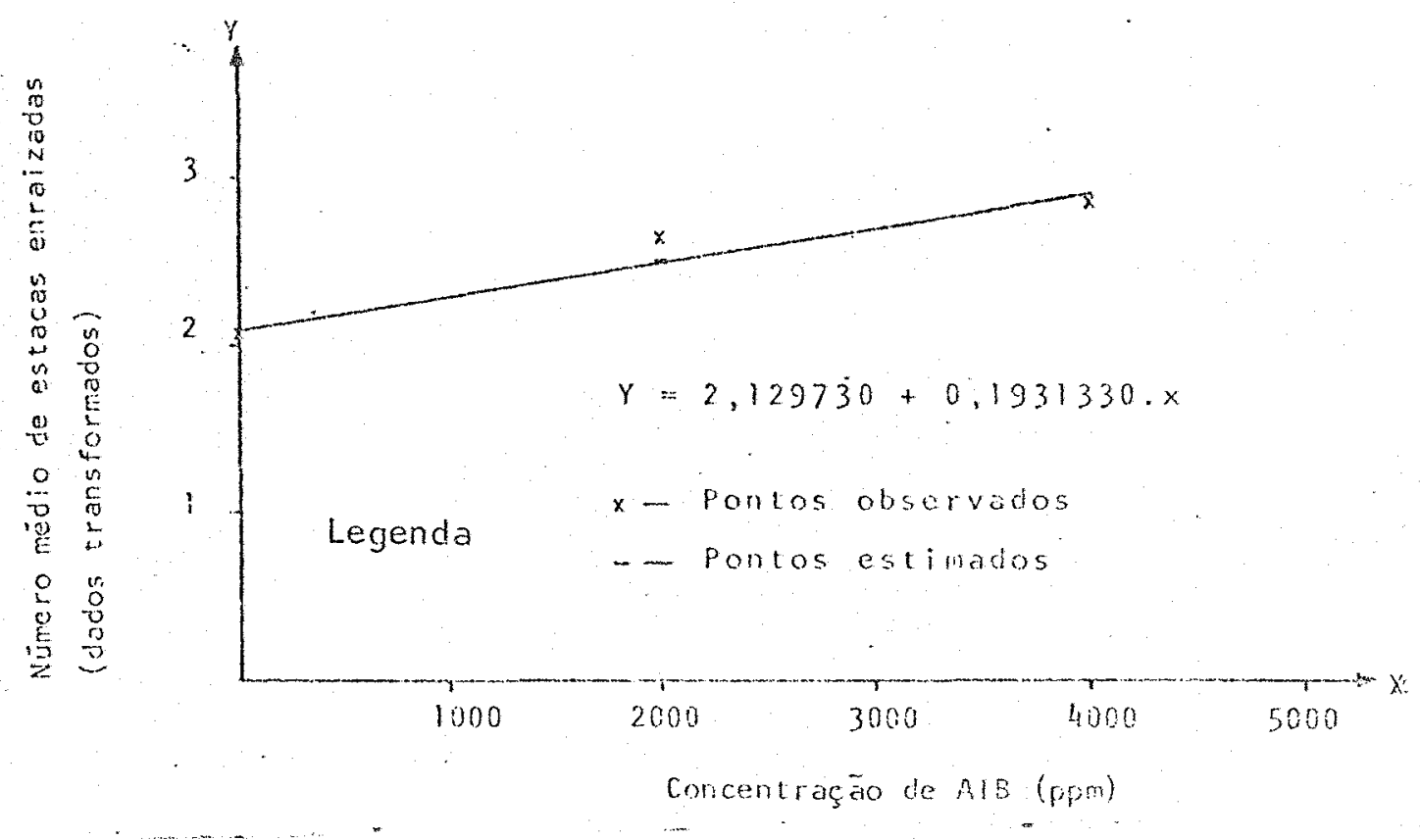

Figura 2. Relação entre nümero de estacas de ramos herbáceos enrai zadas de ameixeira e concentração de AlB, para o culti var Grancuore.



Figura 3. Relação entre nümero de estacas enraizadas de ramos herbá ceos de ameixeira e concentração de AlB para o cultivar Kelsey Paulista. 
4.2. Experimento 2. Regeneracäo de nespereira àtravés de es tacas de ramos hérbàceos

Foram estudados os efeitos do uso da técnica do estiolamento e concentrações diferentes de AlB, em estacas de ramos herbäceos denêspereira, cultivares Mizuhó e Precoce de ltaquerano enraizamento de estacas. os resultados estäo reunidos na tabela 15, no apềndice.

Atravēs da tabela 4, verificou-se que não ocorreram diferenças significativas por influêrcia do cultivar, do estiolamento e da concentração de AIB, assim como para as suas interações. O teste das médias revelou para o cultivar precoce de Itaquera a percentagem de enraizamento ao redor de $52,35 \%$, a qual não defiriu do cultivar Mizuho, com $46,81 \%$

Encontrou-se relação linear entre número de esta cas èralzadas e concentração de AIB, para o cultivar Precoce de Itaquera, o que não ocorreu para o cultivar Mizuho: Como pode se observar na figura 4, com o aumento da concentração de AlB, aumentou tambëm o nümero de estacas enralizadas.

A equação de regressão que melhor se ajustou para essa relação foi:

$$
Y=1,984067+0,2053393 \cdot x
$$

Sua representação gräfica se encontra na figúra. 4 .

A anälise estatística da percentagem de enraiza- 
mento com o uso da técnica do estiolamento para os dois cultiva res mostrou que não houve diferenças significativas. (tabela 5).

TABELA 4. Anäli se da variancia do enraizamento das estacas de ramos her bäceos de néspereira, cultivares Mizuho e Precoce de Itaquera com o uso da técnica do estiolamento associada ao uso de $A / B$ em diferentes concentraçöes

Causas de Variação

GL

QM

Blocos

Cultivares

Estiolamento

Concentração

cuit. $x$ Est.

cult. $x$ Conc.

Est: $x$ Conc.

Cult.x Est.x Conc.

Resíduo

Total

C. V. $(\%)=22,919$
$0,303522.8$

0,1268307 n.s.

0,0035990 n.s.

0,8806611 n.s.

$0,0126413 \cdot \mathrm{n} . \mathrm{s}$.

0,5421765 n.s.

0,1715002 n.s.

0,2061974 n.s.

0,2864917

n.s. = não significativo 


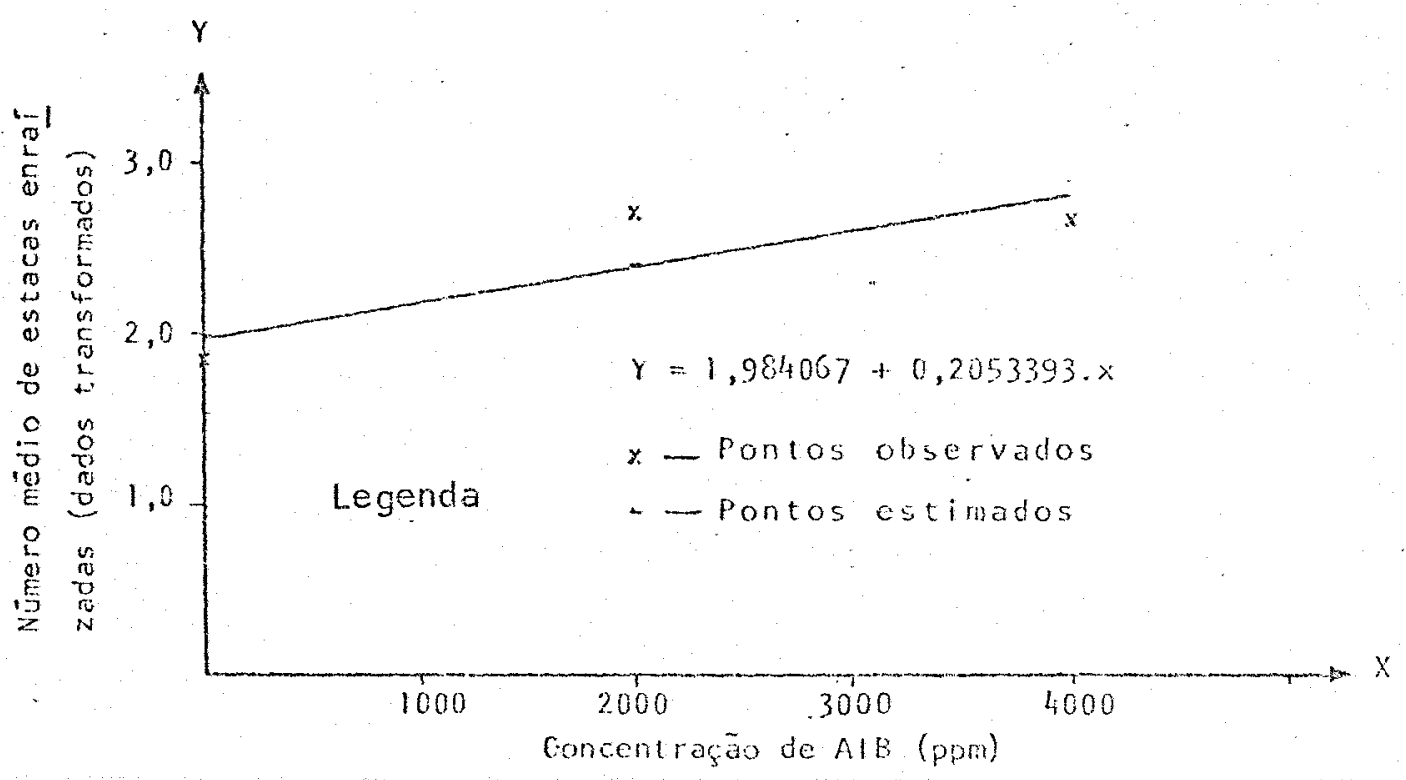

Figura 4. Relação entre nümero de estacas de ramos herbäceos enraizadas de nespereira, cultivar precoce de itaquera e concentrações de AIB. 
TABELA 5. Nümero mëdio de estacas de ramos herbäceos enraizadas de nespe reira, cultivares Mizuho e Precoce de Itaquera, dentro do fator estiolamento.

\begin{tabular}{llll}
\hline Tratamento & Cultivar & $\begin{array}{l}\text { Médias trans } \\
\text { formadas }\end{array}$ & Médias ori- \\
\hline Sern estiolamento & Precoce de ltaquera & 2,423477 & 5,373242 a \\
Mizuho & 2,267279 & 4,640555 a \\
Com estiolamento & Precoce de ltaquera & 2,366014 & 5,098021 a \\
& Mizuho & 2,284798 & 4,720301 a \\
\hline
\end{tabular}

Médias seguidas por letras distintas diferem entre si ao nível de $5 \%$ de probabilidade, pelo teste de Tukey. 
4.3. Experimento 3. Regeneração de a pitancita através de esta cas de ramos hérbäceos

For am estudados os efeitos de materiais juvenil e adulto e diferentes concentraçōes de AlB, no enraizamento de es tacas de ramos herbáceos de pitangueira, cujos dados estão na tabela 16 , no apêndice.

Através da tabela 6 , verificou-se que oconreram diferenças significativas para material e concentração, não havendo interação entre eles. O teste das mëdias revelou que o material juvenil foi o que apresentou melhores resultados, com enraizamento de $65,64 \%$. O material adulto, apresentou somente $14,69 \%$. Conforme pode ser verificado através da tabela 7, ocor reram diferenças por influencia de materiais dentro dos trata mentos controle e das três concentraçōes utilizadas.

O desdobramento da análise, mostrou que houve relação linear entre o nümero de estacas enráizadas e concentra ções de AlB, somente para o material adulto.

- Observou-se na figura 5 que houve aumento do nüne ro de estacas de material adulto enraizadas com aumento das concentrações de A|B.

A equação de regressäo que melhor se ajustou para essa relação foi:

$$
Y=1,056664+0,1979060 \cdot x
$$

cuja apresentação gráfica se encontra na figura 5. 
Verificou-se que o enraizamento das estacas de ma terial juvenil não foi afetado pelo emprego das diferentes concentrações de AlB, embora as estacas de material juvenil tenham apresentado melhores resultados, como pode ser visto na tabe 1 a 7 .

TABELA 6. Análise da variancia do enraizamento das estacas de ramos herbáceos de pitangueira de materiais juvenil e adulto com diferentes concentrações de AlB.

Causas da Variação

GL

QM

B locos

Material

Concentração

Mat. x Conc.

Resíduo
3

1

3

3

21
0,0798842

$12,5966092 * *$

0,6280905

0,1734933 n.s.

0,1350907

- Total 3.1

c.V. $(\%)=18,102$

* =significativo ao nivel de $1 \%$ de probabilidade **=significativo ao nível de $5 \%$ de probabilidade n.s. = não significativo 
TABELA 7. Médias de enraizamento de estacas de ramos herbáceos de pitangueira, de materiais juvenil e adulto, com diferen. tes concentraçôes de AlB.

Concentração de AlB (ppm)
Material

Controle

1000

2000

4000

$$
\text { Juvenil }
$$

Aduil to

Juvenil

Adulto

Juven!l

Adul to
Médias trans

formadas
Médias originais

\begin{tabular}{l}
$1,923652 \quad 3,200438$ a \\
\hline
\end{tabular}

Médias seguidas por letras distintas diferem entre si ao nivel de $5 \%$ de probabilidade, pelo teste de Tukey. 


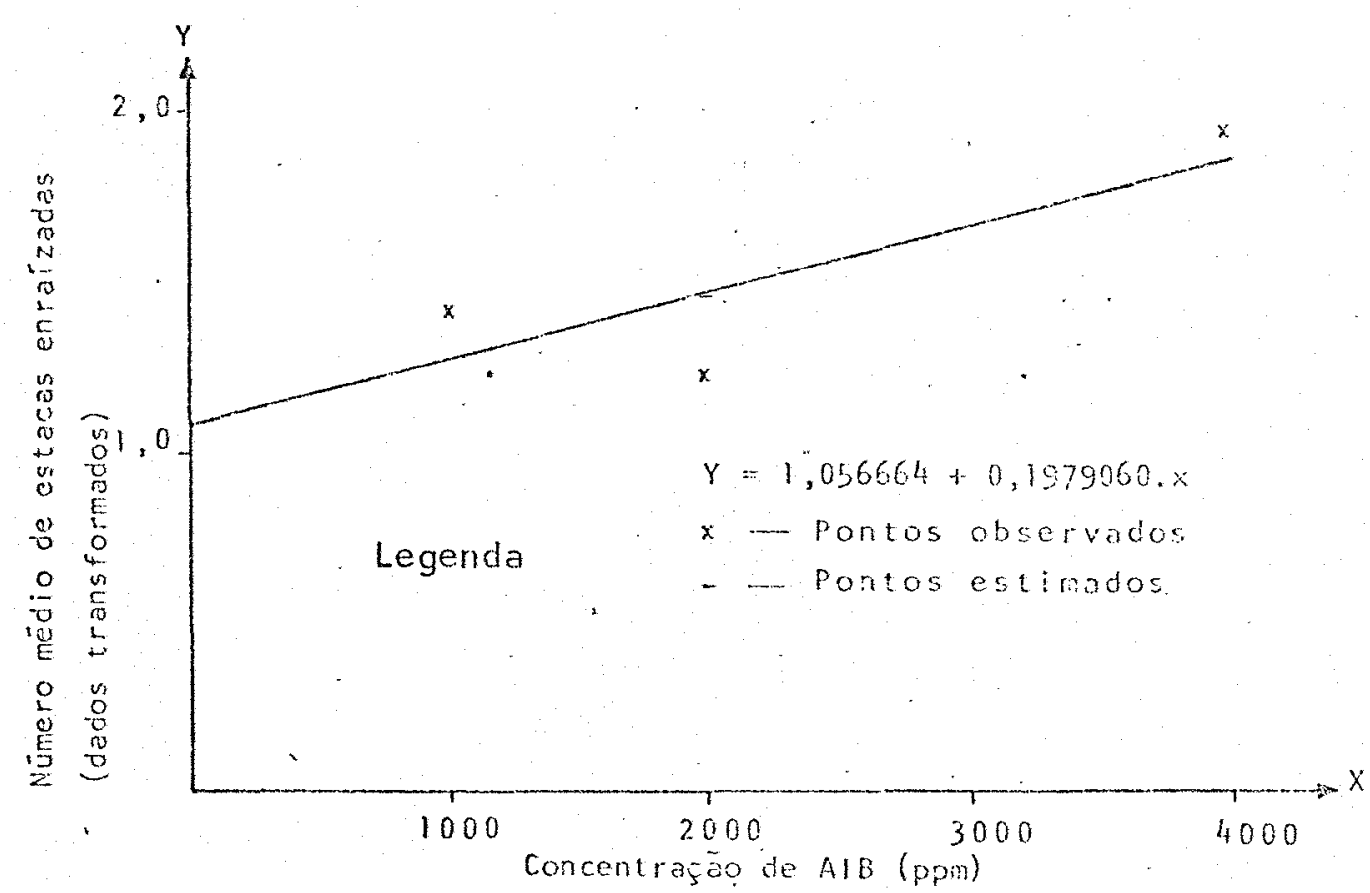

Figura 5. Relação entre nümero de estacas de ramos herbäceos de pitan gueira enraizadas de materiais juvenil e adulto e concentra ções de AlB. 
4.4. Experimento 4. Regeneracäo de nogueira pecã através de estacas de raizes

Foram estudados os efeitos de materiais juvenil e adulto e diferentes diàmetros na percentagem de enraizamento das estacas obtidas de raízes de nogueira pecá. Os dadosobtidos es tão expressos nà tabela 17 no apêndice.

Através da tabela 8 , verificou-se que ocorreram diferenças significativas paramaterial e diametro, assim cocomo para a interação material $x$ diämetro. 0 teste das médias revelou que o material juvenil foi o que apresentou melhor re sultado, com percentagem de $91,36 \%$ de enraizamento das estacas, a qual diferiu do obtido para o material adulto, com $21,13 \%$ e ocorreram diferenças dentro dos três diâmetros de estacas utili zados (tabela 9$)$.

A anălise estatística revelou ainda que para mate rial juvenil, os diàmetros de 1,5 a 2,0 cm foram os que apresen taram melhor percentagem de enraizamento, com $100 \%$, os quais näo diferiram dos diämetros entre 1,0 a: $1,5 \mathrm{~cm} \operatorname{com} 97,45 \%$, mas dife riram dos diâmetros entre 0,5 a $1,0 \mathrm{~cm}$ com $77,45 \%$. Notou-se que para o material adulto, os diâmetros que apresentaram melhores resultados foram aqueles entre 1,0 a $1,5 \mathrm{~cm} \operatorname{com} 32,38 \%$, as quais não diferiram dos diâmetros entre 1,5 a $2,0 \mathrm{~cm} \operatorname{com} 29,63 \%$, mas diferiram daqueles entre 0,5 a $1,0 \mathrm{~cm}$, com $6,13 \%$ de percentagem de enraizamento das estacas, isto pode ser visto na tabela 10 e na figura 6. 
TABELA 8. Anälise da variância dos dados de enraizamento das es tacas obtidas de raizes de nogueira pecáa, de materiais juvenil e adulto com diferentes diametros.

Causas da Variação

Blocos

Material

Diámetro

Mat. x Diâm.

Residuo
GL

$\begin{array}{ll}3 & 0,0678696 \\ 1 & 13,2786437 * * \\ 2 & 0,9470794 * * \\ 2 & 0,1682172 * \\ 15 & 0,0386431\end{array}$

\section{Total}

\section{3}

c. V. $(\%)=8,328$

*=significativo ao nivel de $1 \%$ de probabilidade; $* *=s i g n i f i c a t i v o$ ao nivel de $5 \%$ de probabilidade; n.s.=não significativo.

TABELA 9. Médias de enraizamento de estacas obtidas de raizes de nogueira pecã, para materiais juvenil e adulto, com estacas de diferentes diâmetros.

\begin{tabular}{llll}
$\begin{array}{c}\text { Diâmetro } \\
(\mathrm{cm})\end{array}$ & Material & $\begin{array}{l}\text { Médias trans } \\
\text { formadas }\end{array}$ & $\begin{array}{l}\text { Médias origi- } \\
\text { nais }\end{array}$ \\
\hline $0,5-1,0$ & $\begin{array}{l}\text { Juvenil } \\
\text { Adulto }\end{array}$ & 2,871260 & 7,744135 a \\
$1,0-1,5$ & $\begin{array}{l}\text { Juvenil } \\
\text { Adulto }\end{array}$ & 3,055024 & $0,613076 \mathrm{~b}$ \\
$1,5-2,0$ & Juvenil & 1,933452 & $9,745308 \mathrm{a}$ \\
- & Adulto & 3,240370 & $3,238236 \mathrm{~b}$ \\
& 1,861029 & $9,999998 \mathrm{a}$ \\
& & $3,963430 \mathrm{~b}$
\end{tabular}

Médias seguidas por letras distintas, diferementre si ao ní vel de significância de $5 \%$ de probabilidade, peloteste de Tukey. 
TABELA 10. Mëdias de enraizamento de estacas de raízes de no gueira pecã, com diferentes diâmecros das estacas de materiais juvenil e adulto.

\begin{tabular}{|c|c|c|c|}
\hline Material & $\begin{array}{l}\text { Di àmetros: } \\
(\mathrm{cm})\end{array}$ & $\begin{array}{l}\text { Médias trans } \\
\text { formadas }\end{array}$ & $\begin{array}{l}\text { Mëdias Origi- } \\
\text { nais }\end{array}$ \\
\hline \multirow{3}{*}{ Juvenil } & $0,5-1,0$ & 2,871260 & 7,744135 a \\
\hline & $1,0-1,5$ & 3,200829 & $9,745308 \mathrm{ab}$ \\
\hline & $1,5-2,0$ & 3,240370 & $9,999998 \ldots$ \\
\hline \multirow{3}{*}{ Adul to } & $0,5-1,0$ & 1,055024 & 0,613076 a \\
\hline & $1,0-1,5$ & 1,861029 & $2,963430 a$ \\
\hline & $1,5-2,0$ & 1,933452 & $3,238236 \quad b$ \\
\hline
\end{tabular}

Médias seguidas por letras distintas, diferem entre si ao ni vel de significancia de $5 \%$ de probabilidade, pelo teste de Tukey. 


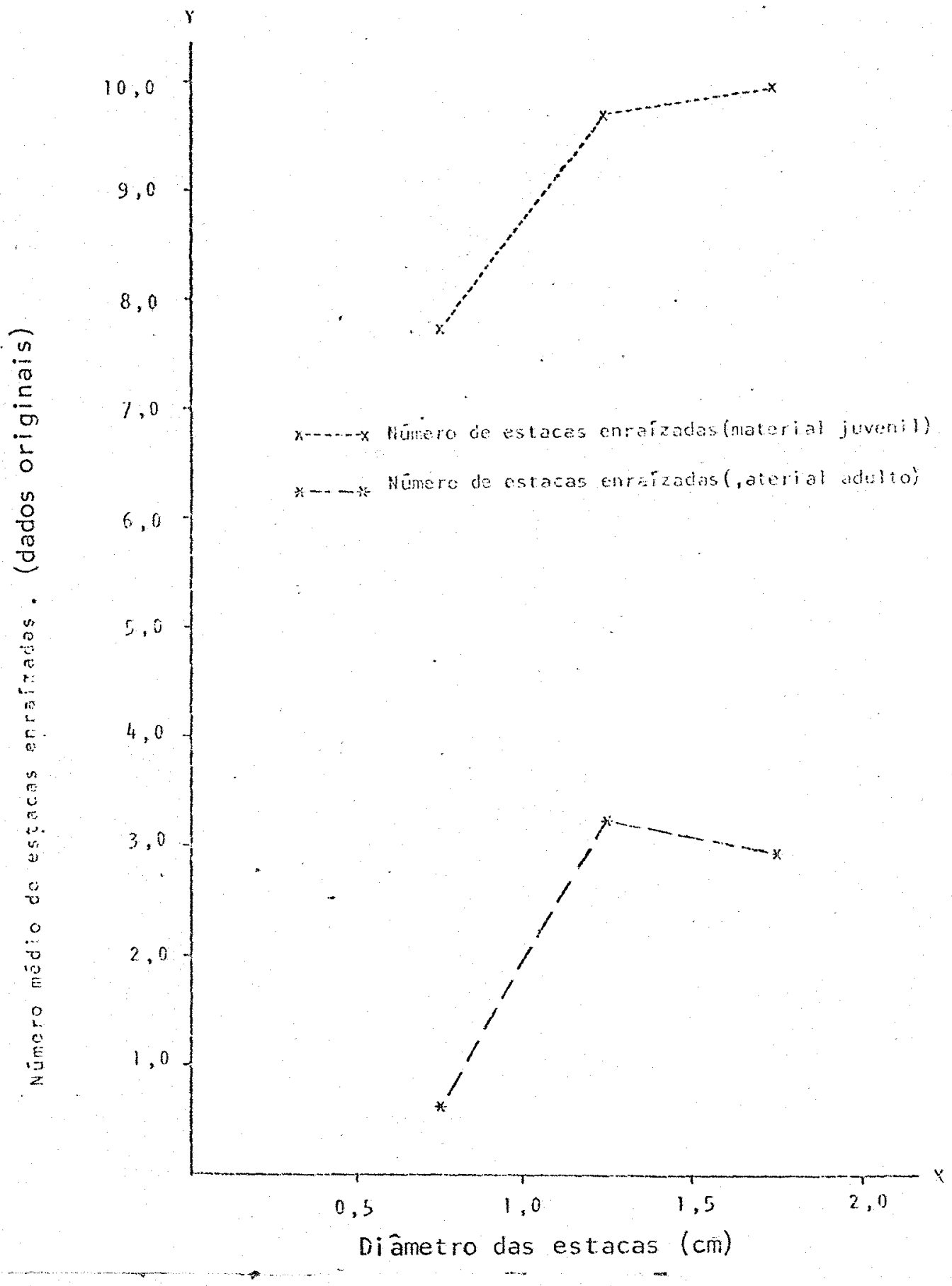

Figura 6. Resultados médios de estacas enraizadas de estacas de raizes de nogueira pecã de materiais juvenil e adulto para diferentes diảmetros dás estacas. 


\subsection{Experimento 5. Regeneracão de pitangueira através de estacas de rafzes}

Foram estudados os efeitos de diferentes substratos sobre o enraizamento de estacas provenientes de materialsju venil e adulto com diferentes diâmetros obtidos de rá́zes de Pitangueira. os dados obtidos estäo expressos na tabela 18 no apêndice.

Verificou-se através da tabela 11 , que ocorreu di ferença significativa para material, não revelando diferença pa ra substrato, diàmetro, assim como não houve interações entre os resuitados.

0 teste de Tukey revelou que o material juvenil foi o que apresentou melhores resultados, com enraizamento de $17,82 \%$ das estacas, ao passo que o material adulto resultou em tão somente $2,00 \%$. Estas diferenças ocorreram de maneira signi ficativa dentro de substratos (tabela 12) e dentro de diâmetro - das estacas (tabela 13). 
TABELA 11. Anälise da variancia do enraizamento de estacas de raizes de Pitangueira para materiais juvenil e adulto influenciado pelos fatores substrato e diametro das estacas.

Causas da Variaçäo

GL

QM

B locos

Material

Substrato

Diámetro

Mat. $\times$ Subst.

Mat. $x$ Di àm.

Subs. x Diàm.

Mat. $x$ Subst. $x$ Dîam.

Resíduo

Total

C.V. $(\%)=22,264$

** =significativo ao nível de $5 \%$ de probabilidade

n.s. não significativo
0,0921714

$2,7265170^{* *}$

$0,0332705 \mathrm{n.s}$.

$0,0111661 \mathrm{n} . \mathrm{s}$.

$0,0332690 \mathrm{n} . \mathrm{s}$.

$0,0111630 \mathrm{n} . \mathrm{s}$.

0,0176588 n.s.

0,0926377 n.s.

$0,0682680 \mathrm{n.s}$. 
TABELA 12. Mëdias de enraizamiento de estacas obtidas de raízes de pitangueira de materiais juvenil e adulto, influenciado pelo fator substrato.

\begin{tabular}{|c|c|c|c|c|}
\hline Substrato & Material & $\begin{array}{l}\text { Médias trans } \\
\text { formadas }\end{array}$ & $\begin{array}{l}\text { Médias } \\
\text { nais }\end{array}$ & origi- \\
\hline \multirow{2}{*}{ areia } & Juvenil & 1,653561 & 2,234265 & $a$ \\
\hline & Adulto & 0,836516 & 0,199760 & $\therefore b$ \\
\hline \multirow[t]{2}{*}{ terra } & Juvenil & 1,475364 & 1,676700 & $a$ \\
\hline & Adulto & 0,836516 & 0,199760 & $b$ \\
\hline \multirow[t]{2}{*}{ vermiculita } & Juvenil & 1,402942 & 1,468246 & $a$ \\
\hline & Adul to & 0.836516 & 0,199760 & $b$ \\
\hline
\end{tabular}

Médias seguidas por letras distintas diferem entre si ao nível de $5 \%$ de probabilidade,pelo teste de Tukey.

TABELA 13. Mëdias de enraizamento das estacas obtidas de raizes de Pitangueira de materiais juvenil e adulto influen ciado pelo fator diâmetro das estacas.

\begin{tabular}{cccc}
$\begin{array}{c}\text { Diämetro } \\
(\mathrm{cm})\end{array}$ & Material & $\begin{array}{c}\text { Médias trans } \\
\text { formadas }\end{array}$ & $\begin{array}{l}\text { Médias origi } \\
\text { nais }\end{array}$ \\
\hline menor que 0,5 & Nuvenil & 1,510623 & 1,781981 a \\
menor que 1,0 & Adulto & 0,879653 & 0,273789 b \\
maior que 0,5 & Juvenil & 1,510623 & 1,781981 a \\
maior que 1,0 & Adulto & 0,793380 & 0,129451 \\
\hline
\end{tabular}

Médias seguidas por letras distintas diferem entre si ao nível de $5 \%$ de probabilidade, pelo teste de Tukey. 
5. DISCUSSÃO

5.1. Experimento 1. Regeneração de ameixeira atravës de estacas de ramos herbáceos

Os cultivares de ameixa Gema de Ouro, Carmesin, Golden Talismã, Grancuore, Kelsey Paulista e Rosa Paulista, mostraram boa capacidade de propagação atravës do emprêgo de estacas herbáceas. As percentagens de regeneração foram respectivamente $88,74 \% ; 85,80 \% ; 79,24 \% ; 58,30 \% ; 58,18 \%$ e $44,20 \%$.

O enraizamento das estacas dos cultivares Carme sin e Golden Talismá mostrou tendência em diminuir com o aumen to das concentrações de AIB, como pode ser observado na tabela 3. Talvez este resultado tenha ocorrido devido ao fato dos - dois cultivares jā apresentarem altas concentrações endógenas de auxina, que foi incrementada com a aplicação do regulador vegetal, causando uma inibição no desenvolvimento das raízes Esses resultados encontraram apoio nas citaçöes que HARTMANN e KESTER (1975) e WAREING (1982) fazem em relação ao uso de dife- 
rentes concentraçöes de regulador vegetal para o enraizamento das estacas. Segundo esses autores as concentraçöes variam com a espëcie, devendo-se realizar provas empíricas antes da aplica ção, pois a aplicação de auxinas em altas concentrações podem inibir o desenvolvimento das raízes.

o enraizamento dos cultivares Gema de ouro e Kelsey Paulista foi incrementado com a aplicação do AlB, ocor rendo regressão linear somente para o ültimo cultivar. Meltor efeito da aplicação de 2000 ppm de AlB, fol observado por ou tros autores, quando trabalharam também com estacas de ameixeira, utilizando-se concentrações variäveis de 500 a 5000 ppm de AlB. Chegaram a conclusäo de que as concentraçöes de 2000 e. $2500 \mathrm{ppm}$, foram as melhores. Entre eles, destacam-se:TEHRAN e LOGAM (1971); NAHLAW e HOWARD (1971 e 1972); BARTOLONO E ROSELLI (1975): NICOTRA E DAMINO (1975) e PATHAK et alii (1975).

o cultivar Grancuore teve o seu enraizamento meIhorado com o aumento da concentração de AlB, resultando como melhor tratamento, a concentração de 4000 ppm de AlB. Estes re sultados discordam dos obtidos pelos autores acima citados, onde encontraram melhores resultados com a aplicação de 2000 ppm. Talvez possa-se afirmar que estas variaçöes no comportamento dos cultivares, estejam relacionadas, com a concentração de auxina endögena existentes nas estacas de cada cultivar.

o cultivar Rosa Paulista por sua vez teve o en raizamento das estacas um pouco aumentado com a aplicação de $4000 \mathrm{ppm}$, como no caso anterior. 
5.2. Experimento 2. Regenerecão de nespereira através de es tacas de ramos herbáceos

Através do presente experimento, verificou-se a possibilidade de se propagar a nêspereira atravës da estaquia herbäcea, embora esse método não se tenha mostrado eficiente. As percentagens de enraizamento foram de $52,35 \%$ para o cultivar Precoce de ltaquera e 46,81\% para o cultivar Mizuho.

Verificou-se que para o cultivar Precoce de lta quera houve aumento do nümero de estacas enraízadas com o aumen to da concentrafão de AlB. 0 melhor enraizamento ocorreu com a concentração de $4000 \mathrm{ppm}$ de AlB. Esses resultados encontra ram apoio nas afirmações de SIMÃO (1971); KRAMMER e KOZLOWSKI (1972); HARTMANN e.t alie (1981) e WAREING (1982), de que o enraizamento das estacas é normalmente melhorado mediante trata mento com reguladores vegetals, que estimulam o enraizamento.

Vários trabalhos foram realizados por outros auto res, com diferentes espécies, os quais conseguiram melhores per centagens de enraizamento tratando as estacas com AlB. Entre esses autores estão: MAXIMOS et alì (1966) com estacas herbáce as de pessegueiro;SEN et alie (1969)com mangueira; TEHRANL e LOGAM (1971), NAHLANI E HOWARD (1971 e 1972). e PATHAK et ali com amei xeira ; BAJWA et alii (1975) com Citrus limettioides Tanaka ; ERNEST e HOLTZHANSEN (1978)com abacateiro, além. de outros.

observou-se tambëm que para diferentes concentraçöes de AlB, no cultivar Mizuho, näo houve influéncia no enrai- 
zamento das estacas. Resultados semelhantes foram observados por BOURDEAUT (1970), que trabalhando com porta-enxerto de aba cateiro Mexicano, não observou grande aumento na percentagem de enraizamento, quando utilizou concentrações de 2000 e 3000 ppm de AlB.

observou-se que o uso de estiolamento, não pro porcionou aumento significativo do enraizamento das estacas, tanto para o cultivar Mizuho como para Precoce de Itaquera. Estiolamentos de plantas inteiras ou ramos inteiros, deixando- se estiolar por um espaço de tempo maior, poderão esclarecer melhor o assunto.

o efeito não significativo do estiolamento no en raizamento das estacas nesse experimento, difere dos resulta dos obtidos por vários autores, com diferentes espécies, os quais obtiveram resultados superiores de enraizamento, quando utilizaram estacas estioladas. Entre eles estão: GARDNER (1937) com estacas de macieira; FROLICH (1951) com abacateiro; SINGH e TEAOTIA (1961) com mangueira; KAWASE (1965) com värias espécies; FROLICH (1972) e MOHAMEDD e SORHAINDO (1984), com abacateiro. 
5.3. Experimento 3. Regenerafão de pitangueira através de estacas de ramos herbäcéos

os resultados obtidos permitiram avaliar a possibillidade da propagação da pitangueira atravēs da estaquia herbá cea.

O material juvenil apresentou maior percentagem de enraizamento das estacas, ao redor de $65,64 \%$, ao passo que o ma terial adulto, resultou em $14.69 \%$. o efeitojuvenilidade jä foi citado por värios autores, entre eles SAX (1962); DOOREMBOS (1965); ZIMMERMANN (1972); HARTMANN E KESTER (1975) E SALISBURY E ROSS (1978). Comentam eles que estacas de raízes ou ramos tomadas de material juvenil enraízam mais facilmente que com material aduito.

Resultados obtidos por outros autores en diferen tes espëcies, tambëm revelaram melhores resultados com material juvenil quando trabalharam com estacas de ramos herbáceos, ertre eles destacam-se SMITH et alii (1974)com macieira, obtendo $82 \%$ de enraizamento das estacas para material juvenil e 20 $30 \%$ para material adulto; HALLIWELL e LARKBEY (1974) com $\mathrm{Cu}$ pressus macrocarpa; ALI e WESTW00D (1968) com Pyrus sp; BHAN DARY e MUKHERJEE (1969), com goiabeira ; STEPANOV e KUZIK (1973) com macieira;TARASENKO et alii (1973)com cerejeira, KADMAN (1976) com abacateiro, além de outros.

Verificou-se também, que embora as estacas obti das de material juvenil tenham apresentado melhor enraizamento 
em relação as obtidas de material adulto, que o efeito da aplicação do AlB, foi revelado somente para o material adulto, Resultados semelhantes a este foram tambem encontrados por PoR LINGS e THERIOS (1976), quando trabalharam com estacas de oli veira, a partir de materiais juvenil e adulto e chegaram a conclusão, de que em estacas juvenis, o AlB não influenciou a percentagem de enraizamento, a qual foi alta, mas por outro lado aumentou o nümero de raízes por estaca. Porém em estacas adultas o AIB respondeu com aumento na percentagem de enraizamento, e no nümero de raízes por estacas. Esses autores afirmaram que nas estacas juvenis a percentagem de enraizamento foi alta sem a aplicação de auxina e não foi aumentada pelo tratamento com auxina, indicando que talvez estas estacas tenham quantidade de auxina endógena suficiente para o seu enraizamento. 0 mesmo não aconteceu para as adultas, nas quals a percentagem de enrai zamento foi aumentada pela aplicação de auxina.

Por outro lado, a maioria dos trabalhos encontrados na literatura, mostraram que os melhores resultados foram encontrados com material juvenil. Verificaram ainda que o AlB, aumentou a capacidade de enraizamento de ambos os materiais juve nil e adulto. Entre eles, destacam-se: MENDILCIOGLU (1968) com - amendoejra, ameixeira, damasqueiro e cerejeira;CHATTERJEE e MUKHERJEE (1980 e 1982)com macieira; ELAZZOUNI et alie (1979) e SMITH e CHIU(1980) com noguéi ra pecã; (1982) com macieira e pessegueiro, além de outros. 
5.4. Experimento 4. Regeneração de nogueira pecã através de estacas de raízes

Atravës do presente experimento verificou-se a possibilidade de propagar a nogueira pecã através da estaquia de raizes.

0 experimento revelou que a percentagem de estacas enraizadas foi maior para o material juvenil, com $91,36 \%$ que para o material adulto, com $21,13 \%$. Estes resultados coincidem com as afirmações de SAX (1962); DOOREMBOS (1965); ZIMMERMANN (1972); BIDWELL (1974); HARTMANN E KESTER (1975) \& SALISBURY O ROSS (1978), de que, tanto as estacas de ramos, como as de raizes tomadas de seedlings (em sua fase juvenil de crescimento), enraizam com maior facilidade que aquelas tomadas de plantas mais velhas.

Resultados obtidos por outros autores, também demonstraram maior percentagem de enraizamento para material juve nil. SMITH et alii (1974), trabalhando com estacas de ramos herbăceos de macieira, verificaram percentagens de $82 \%$ para mate rial juvenil e 20 a $30 \%$ para material adulto, HALLIWELL e LARKBEY (1974) obtiveram 100\% de enraizamento de estacas de ramos de Cupressus macrocarpa, quando utilizaram material juvenil.

Outros trabalhos tambèm foram realizados por vários autores, com estacas de ramos herbáceos, e obtiveram melho res resultados com material juvenil que com o adulto em várias espécies, entre eles, destacam-se: ALI e Westwood (1968) com 
värias espēcies de Pyrus; BHANDARY e MUKHERJEe (1969), com estą cas de goiabeira; STEPANOV e KUZIK (1973) com macieira; TARASEN KO et alie (1973) com cerejeira e ameixeira; NASR e ABDEL-HAMID (1974) com citrus sp; PORLINGS e THERIOS (1976) cornoliveira; KADMAN (1976) com abacateiro, raça Mexicana; CURIR e SULIS(1982) com Eucalyptus sp e DAVIES et alii (1982) con Ficus pumila, 
5.5. Experimento 5. Regeneracão de pitangueira através de estacas de rarzes

o experimento revelou a possibilidade da propagação da pitangueira atravës de estacas de raízes, embora não tenha se mostrado um mëtodo eficiente.

o experimento mostrou também o efeito da juvenili dade, revelando que a percentagem de estacas enraizadas : foi maior para o material juvenil, com $17,28 \%$, do que para o mate rial adulto com $2,00 \%$. Estes resultados coincidem com as afirmações de SAX (1962); DOOREMBOS (1965); ZIMMERMANN (1972) ; BIDWELL (1974); HARTMANN E KESTER (1975) e SALISBURY E ROSS (1978), alëm de outros, de qué material juvenil enraiza melhor que material adulto.

Alguns autores, entre eles SMITH et alie (1974), trabalhando com estacas de ramos herbáceos de macieira, obtiveram percentagens de enraizamento de material juvenil de $82 \%$ e mate- rial adulto de 20 a $30 \%$, também HALLIWELL e LARKBEY (1974), obtiveram 100\% de enraizamento em estacas de ramos herbāceos de Cupressus macrocarpa.

outros trabalhos tambēm foram realizados por và rios autores, com estacas de ramos herbáceos de diferentes espē cies, obtendo-se sempre melhores resultados com estacas de material juvenil, entre eles, ALl eWESTWOOD.(1968) com Pyrus sp; BHANDARY E MUKHERJEE (1969) com goiabeira; STEPANOV e KUZIK (1973) com:macieira;TARASENKO et alii (1973) com cerejeira e ameixeira; NASR e 
96.

ABDEL-HAMID (1974) com citrus sp: KADMAN (1976), com abacateiro; CURIR e SULIS (1982) com Eucalyptus sp, alëm de outros,

Verificou-se tambëm que os substratos areia, ter ra e vermiculita não influenciaram na percentagem de enraizamen to das estacas, diferentemente do que afirmam HARTMANN e KESTER (1975) de que o susbtrato pode influenciar na percentagem de en raizamento das estacas. 
6. CONCLUSÕES

Nas condições em que foram desenvolvidas as pes. quisas, os resultados obtidos permitiram as seguintes conclu söes.

6.1. Experimento 1. Regeneração de ameixeira através de es. taca's de ramos herbäceos

6.1.1. Os cultivares de ameixa Gema de ouro, Carmesin, Golden Talismä, Grancuore, Kelsey Paulista e Rosa Paulista, apresentaram boa capacidade de propagação através do emprego de estacas herbäceas. As percentagens de regeneração obtidas foram respectivamente $88,74 \% ; 85,80 \% ; 79,24 \% ; 58,30 \%$; $58,18 \%$ e $44,02 \%$.

6.1.2. o enraizamento das estacas do cultivar Kelsey Paulista foi melhorado com a aplicą̧ão do AlB. A aplicação de . .2000 Rpm surtiu melhor efeito em relação a de 4000 ppm, sendo este que reve lou resultado inferior ao do tratamento controle. 
6.1.3. O cultivar Grancuore teve o seu enraizamento meIhorado com o aumento da aplicaçăo de AlB, obtendo-se melhores resultados com 4000 ppm.

6.2. Experimento 2. Regeneraçäo de nespereira atravës de estacas de ramos herbácéos

6.2.1. Verificou-se que a nespereira mostrou capacidade de regeneração a partir de estacas herbäceas.

6.2.2. Encontrou-se aumento do nümero de estacas enraizadas com o aumento da concentração do AIB, para o cultivar Precoce de Itaquera, o mesmo não ocorrendo para o cultivar Mizuho.

6.2.3. Observou-se que näo houve influência do uso da técnica de estiolamento no enraizamento das estacas para os dois cultivares: Mizuho e Precoce de Itaquera.

6:3. Experimento 3. Regeneração de pitangueira atravës de estacas de ramos herbáceos.

6.3.1. Verificou-se que a pitangueira mostrou possibili 
dade de propagação atravēs de estacas herbäceas.

6.3.2. O material juvenil apresentou maior percentagem de estacas enraizadas que o material adulto.

6.3.3. Para o material adulto, houve aumento na percen tagem de enraizamento das estacas com o aumento na concen - tração do $A \mid B$.

6.3.4. O enraizamento das estacas de material juvenil não foi afetado pelo emprego do AIB nas diferentes concen trações.

6.4. Experimento 4. Regeneração de nogueira pecã através de estacas de raízes

6.4.1. Verificou-se que a nogueira Pecã mostrou boa capacidade de regeneração a partir de estacas de raízes.

6.4.2. O material juvenil apresentou maiores percentagens de enraizamento das estacas que o material adulto.

6.4.3. As estacas com maiores diâmetros, de 1,5 a 2,0 $\mathrm{cm}$ e 1,0 a $1,5 \mathrm{~cm}$ apresentaram maiores percentagens de enrai zamento,que os diâmetros de 0,5 a $1,0 \mathrm{~cm}$, para materiais juveril e adul to. 
6.5. Experimento 5. Regeneracão de pitangueira através de esta cas de raizes

6.5.1. Verificou-se que apesar de estacas de raizes terem se revelado como método pouco eficiente de propagação a pitangueira apresentou possibilidade de ser assim regenerada.

6.5.2. O material juvenil apresentou maiores percentagens de enraizamento das estacas que o material adulto.

6.5.3. Não houve influência dos diferentes diâmetros es tudados no enraizamento, quer do material juvenil, com diâme tros maiores e menores que $0,5 \mathrm{~cm}$; assim como para o material adulto com diâmetros maiores e menores que $1,0 \mathrm{~cm}$ no enraiza mento das estacas.

6.5.4. 0 uso de diferentes substratos, areia, terra e vermiculita, não influenciou no enraizamento das estacas. 
ACHARYYA, N. E P.C. DASH, 1972. Effect of two growth subs tances or cashew air-layers. Current Science. Bangalore, $41(14): 534-535$

ALI, N. e M.N., WESTWOOD, 1968. Juvenility as related to che mical content and rooting of stem cuttings of Pyrus species. Proceedings of the American Society for Horticultural Science. st. Joseph, 93:77-82.

ALLAN, P., 1973. Mist propagation of leafy cutting. The ci trus and Subtropical Eruit Journal. Natal, 479:5-13.

ALLSOPP, A., 1965. Heteroblastic development in cormophytes. Encyclopedia Plant Physiology. Lancaster, 15(1):1172-1221.

AWAD, M. e P.R. CASTRO, 1983. Introducão à Fisiolögia Vege - 
tal. São Paulo, Livraria Nobel S/A., $177 \mathrm{P}$.

BAJWA, G.S., S. GURCHARAN, A.S. SANDHU E A. KHAJURI, 1977. Rooting of sweet lime (Citrus limmetioides Tanaka) cuttings as affected by the type of cut and indolebutyric acid con centrations. Haryana Journal of Horticultural Science. In dhiana, 6 $6(3 / 4): 115-166$. Apud Horticultural Abstract. East Malling, $48(9): 757,1978$.

BAKUN, V.K., S.P. ZAGURSKII e S.L. ANTONOV, 1982. Comercial striking of softwood cuttings of apple clonal root stocks. Sadovodstvo. Moscou 4(13):232-233. Apud Horticultural Abstract. East Malling $52(18): 505,1982$.

BARTOLINI, G. e G. ROSSELLI, 1975. Studies on the propagation of plums from stem cuttings. Rivista dell Ortoflori frutticolrura 1taliana. Firenzi 59(5):340-347. Apud Horticultural Abstract. East Malling, 46(11):853, 1976.

BASU, E.N.; N.R. CHOUDHURY; T.K. BOSE E P.K. SEN, 1966. ROOting of mango cuttings. Indian Agriculturist. Bangalore, $10(2): 147-151$

BEAKBANE, A.B., 1961. Structure of the plant stem in relation to adventitions rooting. Nature. London, 192(9):954-955.

BHANDARY, K.R. e S.K. MUKHERJEE, 1969. Relation between invi- 
goration and rooting of guava (Psidium guajava, L.) stem cut tings. Current Science. Bangalore, 38(8):197-198.

BHANDARY, K.R. E Y.T. SHIVASHANKER, 1974. Mist propagation of cacao. Journal of Plantation Crops, Karnataka, 2(1):20-22. Apud Horticultural Abstract. East Malling, 46(1):62, 1976.

BHARATH, S., 1970. Guava propagation from stem cuttings in Trinidad. J. Agric. Soc. Trin. Tob., Trinidade, 70:396-399. Apud Horticultural Abstract. East Malling, $41(3): 182,1971$.

BHUJBAL, B.G., 1972. Effective concentrations of IBA in the air-layering of guava. Research Journal of Mahatma Phull Agricultural University. Poona, 3(1):53-56. Apud Horticul tural Abstract. East Malling, 43 (12):807, 1973.

BID, N.N. e S.K. MUKHERJEE, 1969. Varietal response to etiola tion and growtb.. regulator treatment in air-layering of mango (Mangifera indica L.). Indian Journal of Agricultu ral Science. New Delhi, 39:1013-1019.

BID, N.N. e S.K. MUKHERJEE, 1972. Studies into the effects of forced shoot etiolation and different media on the roota ge of (Mangifera indica L.) cuttings. Acta Horticulturae. India, 24:77-81. Apud Horticultural Abstract. East Mal ling, 43(2):178, 1973. 
BIDWELL, R.G.S., 1974. Plant Physiology. N. York, Macmillan Publishing, $473 \mathrm{p}$.

BLAIR, D.S.; M. MACARTHUR e S.K: NELSON, 1956. Observations in the growth phases of fruit trees. Proceedings of the Tropi cal Region American Society for Horticultural Science. Michigan, $67: 75-79$.

BOODLEY, J.W. e R. JR. SHELDRAKE, 1969. Carnation production in vermiculite amended media. Journal of Horticultural sci ence, $94: 512-514$.

BOURDEAUT, J., 1970. Le bouturage de l'ovacatier in cotê D' Ivoire. Fruits d' outre Mer. Paris. 25(9):605-612.

CHASE, S.B., 1947. Propagation of thorn less honey locust. Journal Forestry. Washington, 45:715-722.

CHATTERJEE, B.K. e S.K. MUKHERJEE, 1980. Anote on the effect of leafy and non - leafy cuttings rooting of jack-fruit (Artocarpus heterophyllus, Lan). Progressive Horticulture. Calcuta, 11(4):49-51. Apud Horticultural Abstract. . East Malling, $51(2): 179,1981$.

CHATTERJEE, B.K. e S.K. MUKHERJEE, 1982, Studies on the efficacy of rates and methods of application on indolebutyric a cid $(A \mid B)$ on the rooting of cuttings of jack-fruit (Artocar 
pus heterophylus Lam.). Science and Culture. Calcuta, 48 (2) $: 74-75$.

CHAUHAN, K.S. E T.S. REDDY, 1974. Effect of growtih regulators and mist on rooting in stem cuttings of plum (Prunus persica Batsch). Indian Journal of Agricultural science. New Delhi, $42(9): 769-771$.

CHAUHAN, K.S. E T.S. REDDY, 1974. Effect of growth regulators and mist on rooting in stem cuttings of plum (Prunus domestica, L.). The Indian Journal of Horticulture. Bangalore, $\underline{31}(3): 229-231$.

CURIR, P. e S. SULIS, 1982. A study of rhizogenesis in cut tings of Eucalyptus stuartina. Mull, Eucalyptus grunnitook e Eucalyptus cinerea F. Mul. Annali dell Istituto Speri mentale per la Floricoltura. San Remo, 13(1):63. Apud Horticultural Abstract. E. Malling, 54(12):905, 1984.

DAVIES, F.T.Jr.; J.E. LAZARTE e J.N. JOINER, 1982. Initiation and development of roots in juvenile and mature leafy bud cuttings of Ficus pumilla, L. American Journal of Botany. Florida, 69(5):804-811.

DHUA, R.S.; S.K. SEN E T.K. BOSE, 1983. Propagation of jack fruit (Artocarpus heterophyllus Lam.) by stem cuttings. Puni 
jab Horticultural Journal. West Bengal, 23(1/2):84-91. Apud Horticultural Abstract. East Malling, $54(1): 378,1984$.

DIAS, R.A., 1973. Aplicação da vermiculita em alfobres. Sil vicultura. São Paulo, 8:99-109.

DIAZ, J.C.H. e M.A. SANTIAGO, 1978. Estudio de algunos facto res que afetam al prendimento de Estacas Duras de Populus y Acer. CHAPINGO. Chapingo, 9:3-9.

DOOREMBOS, J., 1965. Juvenile and adult phases in woody plantas. Encyclopedia of Plant Physiology. Lancaster, 15 (1): $: 1222-1235$.

DUNBERG, A., 1977. Juvenile Maturation ageing and rejuvena tion in woody plants. In Simposio de Upsala, Sweden. Vegeta tive propagation of foreste trees - physiology and practi ces. Upsala, 175 p. 55-64.

DUNHAM, C.W., 1967. Nutrition of green house crops in soil with added peat moss and vermiculite. Proceedings of the American Society for Horticultural Science. St. Joseph, 90: $: 462-466$.

ECCHER, T. e L. FORMENTI, 1974. Rooting trials with softwood cuttings of Prunus sinensis. Rivista della ortoflorofrutti 
cultura Ltaliana, Milão 58(6):443-55. Apud Horticultural Abstracts. East Malling, 45(12):876, 1975 .

EL-AZZOUNI, M.N.; G.R. STINO e BARAKAT, M.R., 1979. Studies on the rootablity of pecan cuttings. Research Bulletin. Cairo, $1105,16 \mathrm{p}$. Apud Horticultural Abstract. East Mal ling, $51(2): 87,1981$.

ERNST, A.A. E L.C. HOLTZHANSEN, 1978. New promissing tecni que for rooting difficult to root avocado (Persea americana Mil1.) cuttings. The Citrus and Subtropical Fruit Journal. Natal, $532: 6,7$ e 10 .

EVANS, H., 1951. Investigations on the propagation of cacao. Tropical Agriculture. Saint Augustine, 28:147-203.

FERNENDES, P. de S.; E. de S. BAENA e C.J. COUTINHO, 1973. Uti - lização da vermiculita no Plantio de Essencias florestais. Silvicultura. São Paulo, 2:282-284.

FERNANDES, P. de S.; E. de S. BAENA; C.J. COUTINHO E J.C. GON ÇALVES, 1973. Produção de mudas de Eucaluptus saligna em bandejas de isopor. Silvicultura. São Paulo, 9:285-286.

FORDHAM, A.J., 1982. Elliotia - propagation e data for four species. Combined Proceedings International Plant Propaga tors Society. Massachussets, 31:436-440. Apud Horticultu - 
ral Abstract. East Malling, 53(12):860, 1983.

FRETZ, T.A.; P.A. READ e M.C. PEELE, 1979. Plant Propagation Lab. Manual, Minneapolis, Burgess Plublishing Company, $479 \mathrm{p}$.

FROLICH, E.F., 1951. Rooting guatemalan avocado cutting. California Avocado Society Yearbook. California, 36:136-138.

FROLICH, E.F., 1972. Use of the etiolation technique in room ting avocado cuttings. California Avocado Society Year book. California, 55:97-109.

FURYA, M. e J.G. TORREY, 1964. The reversible inhibition by red and for red light of auxin induced lateral root inhib! tion in isolated pea roots. Plant Physiology. Lancaster, 39: $987-991$.

GALSTOW, A.W. E R.S. BAKER, 1953. Studies on the physiology of light-action. Photoindictive alteration of auxin-me tabolism in etiolated pear. American Journal of Botany. New York, 38:190-105.

GARDNER, F.R., 1937. Etiolation as a method of rooting apple variety stem cuttings. Proceedings American society for Horticultural Science. St. Joseph, 34:323-329. 
GONĢALVES, A.N., 1982. Revisão à Juvenilidade e Clonagem de Eucalypius urophylla, St. Blake "in vitro". Piracicaba, 97 p. (Tese de Doutoramento).

GOWDA, N., 1983. Studies on vegetative propagation of Tama rind (Tamarináus indica, L.) by air-layering. Thesis Abs tracts. Haryana, 9(3):276-277. Apud Horticultural Abstract. - E. Malling, 54(7):104, 1984 .

GRUNBERG, J.P., 1928. EI arte de criar e injetar frutales, 2a. ed., Buenos Aires, Editorial Franco, $204 \mathrm{p}$.

HALLIWELL, B. \& F. LARKBEY, 1974. Propagation of golden forms of Cupressus macrocarpa. Plant Propagators, Kew, U.K. 20 (1):12-13. Apud Horticultural Abstract. E. Malling, 44(12): $: 882,1974$.

HANSEN, G.1. e H.T. HARTMANN, 1966.. Propagation of temperature - zone fruits plants. California, $50 \mathrm{p}$.

HARRISON-MURRAY, R.S., 1982. Etiolation of stock plants for improved rooting of cuttings. 1. opportumes suggested by work with apple. Combined Proceedings International Plant Propagation Society. California, 31:386-392. Apud Horticul tural Abstract. E. Malling, 53(11):179, 1983. 
HARTMANN, H.T. e H.T. KERTER, 1975. Plant Propagation. New Jersey, Prentice - Hall, $662 \mathrm{p}$.

HARTMANN, H.T.; W.J. FLOCKER E A.M. KOFRAWEK, 1981. Plant Science Growth, Development and Utilization of Cultivated Plants. New Jersey, Prentice - Hall, $676 \mathrm{p}$.

HERMANN, D.E. e C.E. HESS, 1963. The effect of etiolation upon the rooting of cuttings. Combined Proceedings Inter national Plant Propagation Society, 13:42-62.

HILLER, C., 1951. A study of the origin and development of callus and root primordia of Taxus chespidata with reference to the effects of growth regulator. Plant Physiology. Lancaster, $36(21): 354-370$.

KADMAN, A., 1976. Effect of the age of juvenile.stage avocado seedlings on the rooting capacity of their cuttings. Ca lifornia Avocado Society Yearbook. California, 58:58-60. Apud Horticultural Abstract. E. Malling, 47(9):737, 1977 .

KAPETANOVIC, N.; M. BULJKO e D. BULUM, 1972. Vegetative propa gation of local plums for rootstock production, Jugoslo . vensko vocarstivo. Sarajevo. $5(17 / 18): 309-16$. Apud Horticultural Abstract. E. Malling, 43(6):354, 1973 . 
KAWASE, M., 1964. Centrifugation rhizocaline and rooting in Salix alba, L. Physiologya Plantanum. Copentiagen, 17:855-65 .

KAWASE, M., 1965. Etiolation and rooting in cuttings. Physio logya Plantarum. Copenhagen, 18:1066-1076.

KOLENISKOV, V., 1964. Fruit Biology. Moscou, Mis Publisher, $328 \mathrm{p}$.

KOSTEWICZ, S.R. E J.J. LOCASCIO, 1976. Effects of production media, cultivar and fertilizer on yield of greenhouse tomá tos. Proceedings of the Florida State Horticultural Socie ty Florida. Florida, 89:129-131.

KOZLOWSKI, T.T., 1971. Growth and Development of trees. New York, Academic Press, $472 \mathrm{p}$.

KRAMMER, P.J. e T. KOZLOWSKI, 1972. Fisiologia das Arvores. Fundação Caloustre. Mëxico. $745 \mathrm{p}$.

LANGARAJAPPA, V.G., 1982. Studies on the effects of pre treat ments and growth regulators on rooting of jack (Artocarpus heterophyllus, Lam.) air - layers. Thesis Abstracts. Ban-




LARCHER, J., 1970. La multiplication du poivier el l'usation des hormones de boutorage. Agronomie Tropical. Paris, 25: $: 745-764$.

LATHOP, J.K. e R.A. MECKLENBURG, 1971. Root regeneration and root dormancy in Taxus spp. 1 . Amer. Soc. Hort. Sci., 96 : $: 519-522$.

LEE, C.1. E P. HACKETT, 1976. Root Regeneration of transplanted Pistaci chenensis Bunge seedlings at different at diffe rent growth stages. J. American Society for Horticultural Science, 101:236-240.

LEE, C.I. e N. ZIESLIN, 1978. Root Regeneration of Manetti Rootstocks Grafted with different scion cultivars of Rose.. Hort. Science, St Josept, 13(6):665-666.

- maximos, S.E.; Z.I. ZIDAN e M.H. El-BARKouvy, 1966. Effect of indolebutyric acid and gibberelic acid on the rooting of shalil peach hardwood cutting. Ann. Agric. Science. Cai ro, 11:243-7. Apud Horticultural Abstracc. E. Malling, $l_{11}$ (3):1007, 1971.

MENDILCIOGLU, K., 1968. Investigation on the propagation of important fruit species by cuttings. Eje Universitese Ze riaat Dergisi. 1zmir, A $\underline{5}(2): 171-195$. Apud Horticultural Abstract. E Malling, 43(12):807, 1973. 
MINAMI, K., s.d. Utilização da Vermiculita na floricultura e Paisagismo (mimeografado). Piracicaba-ESALQ, 3 p.

MOHAMED, S. E C.A. SORHAINDO, 1984. Production and rooting of etiolated cutting of west Indian and hybrid avocado. Tropical Agriculturist. Piradenya., 61 (3):200-204.

MUCKADELL, M.S., 1959. Juvenile stages in woody plants. Phy siologia plantarum. Copenhagen, $7: 782-796$.

MUKHERJEE, S.K. e N.N. BID, 1965. Propagation of mango (Mangifera indica L.). 11. Effect of etiolation and growth regula tors treatments on the sucess of air-layering. Indian Journal of Agricultural Science. New Delhi, 35(4): 309-314.

MUKHERJEE, S.K.; P.K. MAJUMDER; N.N. BID e A.M. GOSWANI, 1967. Standardization of rootstocks om mango (Mangifena indica L.) 11. Studies on the effects on source invigoration and etiolation on the rooting of mango cuttings. Journal of Horticultural Science. London, $42: 83-87$.

MUKHERJEE, S.K. e P.K. MAJUNDER, 1972. Vegetative propagation of tropical and subtropical fruits crops. Indian council of Agricultural Research, 38 p. Apud Horticultural Abstract. E. Malling, 54(5):278, 1984. 
NAHLAWI, N. e B.H. HOWARD, 1971. Improvement of rooting in plum cuttings. A.R.E. Malling Res. Stat. Maidstone, 46 (1) $: 45-46$.

NAHLAWI, N. E B.H. HOWARD, 1972. Rooting response of plum hardwood cuttings to IBA in relation to treatment duration and cutting moisture content. Journal of Horticultura Science. London, 47(3):301-307.

NASR, T.A. e A. ABDEL-HAMID, 1972. Regeneration of juvenile and mature stem cuttings of sour orange an cleopatra mandarin. Alexandria Journal of Agricultural Research. Alexandria, 19(2):331-341. Apud Horticultural Abstract. E. Malling, $44(1): 60,1974$.

NICOTRA, A. e C. DAMIANO, 1975. Rooting trial of several peach and plum varieties by hardwood cuttings. Acta Horticultu ral, 54:63-70.

NUNES, R.F.M.; E. KERSTEN; B.C. SANTOS E A.A. MACHADO, 1982 . Influência do àcido indol butirico (A|B) no enraizamento de estacas semi - lenhosas de figueira (Ficus carica L.) Roxo de Valinhos em condições de nebulização intermitente. Proceedings of the Tropical Region American Society for Horticultural science, Michigan, 25:235-40. 
NYOMORA, A.M.S. E N.A. MNZAVA, 1982. Rooting responses of juve nile and adult cuttings of apple (Malus sylvestris, L.) and peach (Prunus persica, L.) to indole-3-butyric acid (IBA) and peason in Tanzania. Tanzania, 20 (2):135-140. Apud Horticul tural Abstract. E. Malling, 53(8):552, 1983 .

PADUA, T. de, 1983. Propagação das ärvores frutíferas. Infor me Agropecuärio. Belo Horizonte, 101(1):11-19.

PATHAK, R.K.; D. PANDEY E V.S. PANDEY, 1975. Effect of IBA concentrations and botton heat on the rooting of plum cut tings. Progressive Horticulture. Chambattia, Z(2):17-21. Apud Horticultural Abstract. E. Malling, 46(1):853,1976.

POLIKARPOVA, F.Y.A., 1972. The role of plant etiolation in the propagation of softwood cuttings. Sadovodstvo. Belorussian, 16:106-i12. Apud Horticultural Abstract. E. Malling, $42(4): 846,1972$.

PORLINGS, I.C. E J. THERIOS, 1976. Rooting response of juvenile and adult leafy olive cuttings to various factors. Jour nal of Horticultural Science. London, $51(1): 31-39$.

PROKHOROVA, T.B. E F.Y. POLIKARPOVA, 1974. Propagation of clonal rootstock by softwood cuttings. Plodododstvo i Yago dovadstvo. Moscou, 25:220-227. Apud Horticultural Abs tract. E. Malling, $44(8): 470,1974$. 
REDDY, Y.N. e P.K. MAJUMDER, 1975. Botton heat a new technique for rooting hardwood cuttings of Tropical fruits. Current Science. Bangalore, $44(14): 517-520$.

REDDY, Y.N.; P.K. MAJUMDER, R.M. PANDEY E R.N. SINGA, 1975

Phytochromo mediated root regeneration in mung. (Phaseolus aureus, Roxb.). and mango (Mangifera indica L.) cuttings Current Science. Bangalore, 44(14):509-517.

RICHARDSON, S.D., 1958. The effect of IAA on root development in Acer saccharinum L. Physiol Plant, 11:698-709.

ROMBERG, L.D., 1944. Some characteristics of the juverile and the bearing pecan tree. Proceedings American Society for Horticultural Science. Michigan, 44:255-259.

ROWELL, 0.J., 1982. Etiolation of plants for the improved roo ting of cuttings. 11. Inhial experiences with handy orna mental nursery stock. Proceedings International Plant Pro- pagation Society. Camdbrige, 31:392-397. Apud Horticultural Abstract. E. Malling, 53(8):393, 1983.

SANTOS, M.C., 1968. Manual de Jardinagem, Rio de Janeiro. Livraria Bastos, $320 \mathrm{p}$.

SALISBURY, F.B. e F.B. ROSS, 1978. Plant Physiology. 2a. ed. California, Wadsworth Publishing Company, Inc. Belmont, $422 \mathrm{p}$. 
SAX, K., 1962. The control of vegetative growth and the induc tion of early fruiting in apple tree. Proceedings of the American Society for Horticultural Science. Michigan, 82: $: 684-687$.

SCHMIDT, G., 1982. Different methods of etiolation for increa sing the rooting of the silver lime, Lilia tomentosa soft wood cuttings. In: "Abstract" $X X 1$. St. International Horti cultural Congress. German, 322 p. Apud Horticultural Abstract. E. Malling, 52(12):796, 1982 .

SEN, P.K.; T.K. BOSE E T. SASHIBHUSAN, 1969. Propagation of mango (Mangifera indica, L.) by ari-laryering with growth substances. Indian Agriculturist. Bangalore, 5:167-172.

SHAPIRO, S., 1958. The role of light in growth of root primor dio in the stem of the Lembarby pepler. Physiology of Forest Trees. N. York. 18:445-465.

SHARMA, K.K., 1975. Effect of IBA on rooting of cuttings of guava (Psidium guajava, L.). Prunjab Horticultural Journal Indhiana. 15 (1/2):46-47. Apud Horticultural Abstract. E. Malling, $46(11): 907,1976$.

SIMÃo, S., 1971. Manual de Fruticultura. Säo Paulo, Editora Ceres, $530 \mathrm{p}$. 
SINGH, S.N. E S.S. TAOTIA, 1961. Effect of some hormones on the rootage of mango. Science and Culture. Calcuta, 17 : :207-210.

SINGH, S.M. e N.V.S. GAUR, 1966. Propagation of guava (Psi dium guajava Linn.) by rootage. II. Effect of plantingenvironment and indole-3-butyric acid on the performance of different types of stem-cuttings. B.V.J.Agricultural Scien ce Research. Bichpiri, 8:6-11. Apud Horticultural Abs tract. E. Malling, 41(1):315, 1971 .

SMITH, I.E.; B.N. WOLSTENHOLME E P. ALLAN, 1974. Rooting and stablishment of Pecan (Carya illimoensis (Wang) Kock) stem cuttings. Agroplantae. Pretoria, $\underline{6}(2): 21-28$.

STEPANOV, S. e E.N.KUUZIK, 1973. The rooting capacity of apple layers in relation to their ontogenic state Del'shozyain. Trenaya Biologya, Michuvinsk, $8(6): 928-930$. Apud Horticuitural Abstract. E. Malling, 44(8):471, 1974 .

STOUTEMEYER, V.T. e F.L. O'ROURKE, 1945. Rooting of cutting from plants sprayed with growth regulators substances. Proceedings of the American Society for Horticultural Science. Michigan, $46: 407-411$.

STREET, H.E. E H. OPIK, 1970. Fisiologia das Angiospermas, Cres cimento e Desenvolvimento. Säo Paulo, $372 \mathrm{p}$. 
SULLADMAHT, U.V. e S.D. KOLOLG, 1969. Synergistic influence of 3 indolebytyric acid and alphanaphthalene acetic acid on the rooting of air-layer of chiku (Achras zapata, L.) var. Kalipatti, S. Indian Horticulture 17:9-17. Apud Horticultural Abstract. E. Malling, $41(1): 346,1971$.

SYKES, J.T. E B.B. HOWARD, 1969. The effect of temperature, light intensity and carbohydrate content on the rooting of cuttings under mist. Proceedings of the American Society for Horticultural Science. Michigan, 83:433-434.

TARASENKO, M.T.; M.A. AGAFANOVA e T.E. USEVICH, 1973. The effect of juvenility on regeneration processes during vegetative propagation of sour cherry and plum. Iimiryazevs kaya Sel'shohoyzarstennoi Akademi. U.R.S.S., 6:111-123. Apud Horticultural Abstract. E. Malling, 44(10):118, 1974 .

TEAOTIA, S.S. e I.C. PANDEY, 1961. Effect of growth substan ces on the rooting of guava stem cutting. Science and culture. Calcuta, 27:442-444.

TEHRANI, G. E P.R. LOGAM, 1971. I mprovement of rooting in plum cuttings. A.R.E. Malling Research State. Maidstone, A. $\underline{54}: 45-46$. 
TORREY, J.G., 1952. Effects of light on elongation and bran ching in pea roots. Plant Physlology. Lancaster, 27:591 -602 .

THAKURTA, A.G. e B.K. DUTTA, 1941. Vegetative propagation of mango from goote (marcothe) and cutting by treatment with high concentration of auxin. Current Science. Bangalore, $10: 297-300$.

WALLY, Y.A.; M.M. EL-HAMADY; S.T. BOULOS E M.M. ABU-AMARA, 1981. Rooting experiments on guava using stem cuttings . Egyptian Journal of Horticulture. Egito, $8(1): 77-87$. Apud Horticultural Abstract. E. Malling, $\underline{52}(7): 195,1982$.

WAREING, P.F., 1982. Plant Growth Substances. N. York, Aca demic Press, $683 \mathrm{p}$.

WEAVER, R.J., 1972. Plant Growth Substances in Agricultura . San Francisco, W.H. Freeman e Co, 544 p.

WEAVER, R.J., 1976. Reguladores de crescimento nas plantas e en la Agricultura. México, Ed. Triela, 439 p.

WENT, F.W.;J.BONNER E G.C. WARVOR, 1938. Aneuri and the rooting of cuttings, Science. California, 87:170-171. 
WRIGHT, R.C.M., 1975. The complete Handkook of plant propagation. N. York. Mac. Millan Publishing Co. Inc. $191 \mathrm{p}$.

ZIMMERMANN, R.H., 1972. Juvenility and Flowering in woody plants. Hoct Science. St. Joseph, $\underline{Z}(5): 447-455$. 
A P E N D I C E 


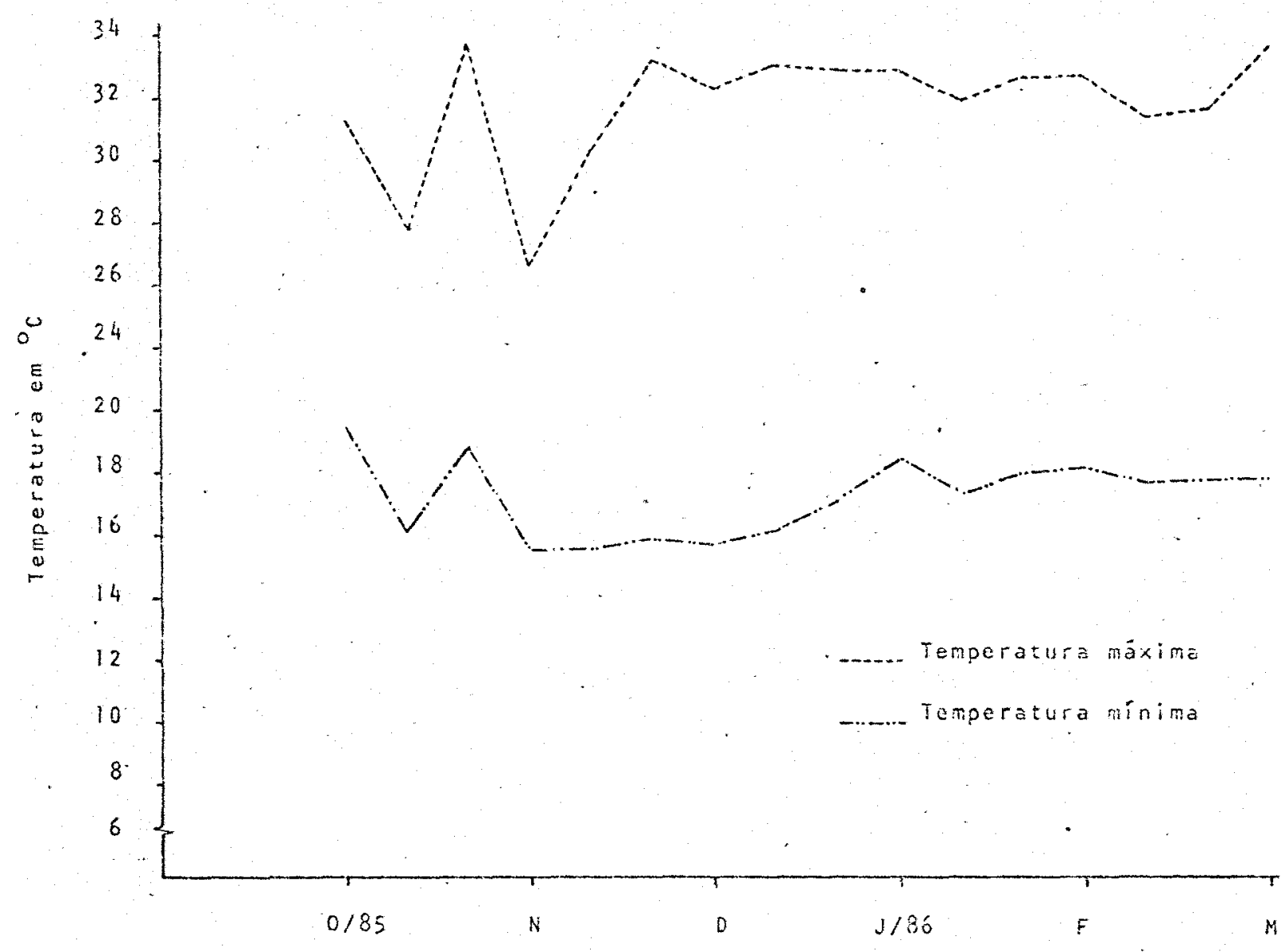

Figura 7. Médias a cada 10 dias das temperaturas mäximas e mínimas, em ${ }^{\circ} \mathrm{C}$ durante os meses de outubro de 1985 a março de 1986 , obti das em casa-de-vegetação. 
123.

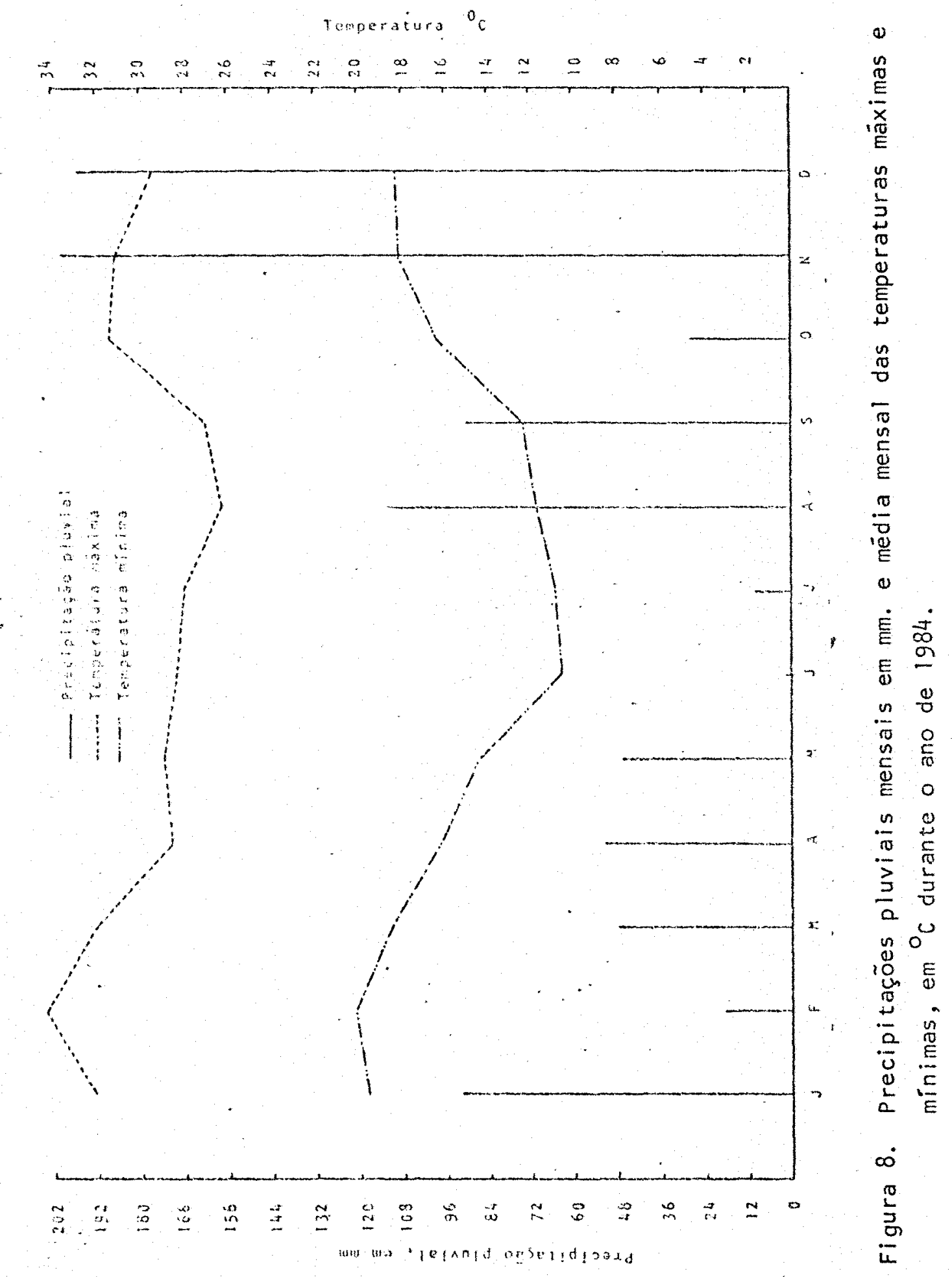




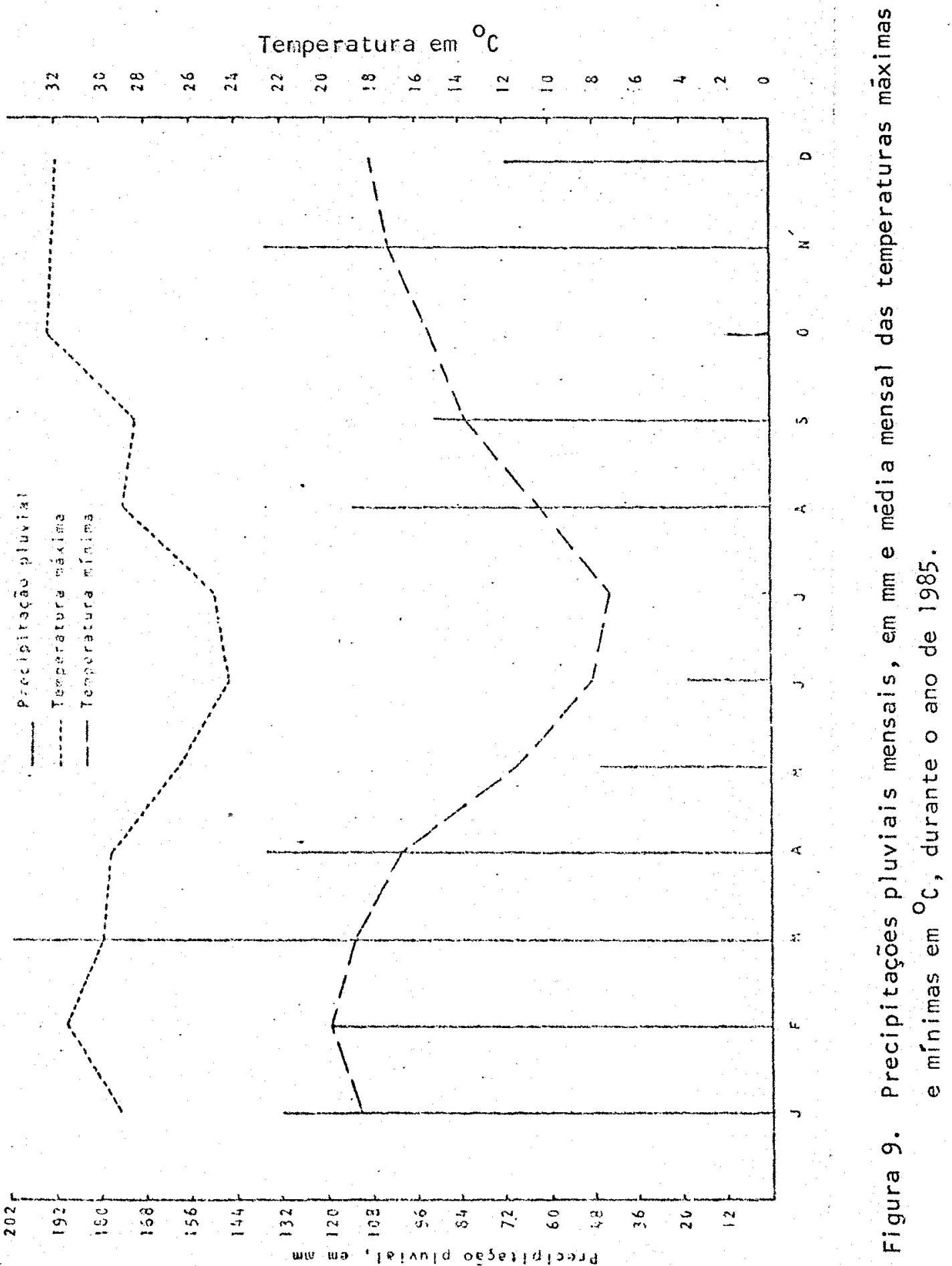


TABELA 14. Resultados das avaliações de enraizamento das estacas de ramos herbáceos de seís cultivares de ameixa, com diferentes concentraçöes de AlB.

Tratamento:

Número de estacas enraizadas repetições

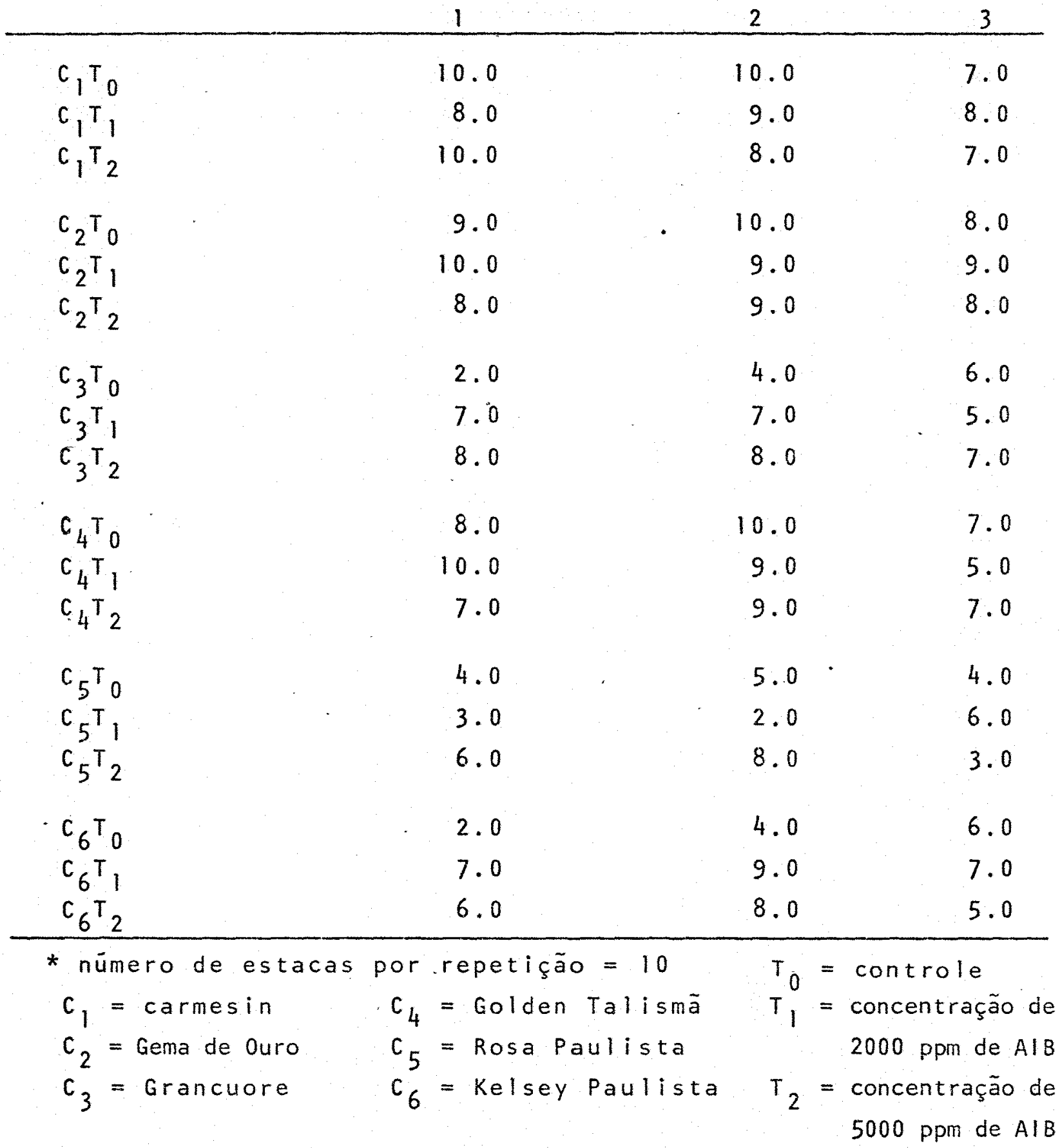


TABELA 15. Resultados das avaliações de nümero de estacas de ra mos herbäceos enraizadas de dois cultivares de nêspera, Mizuho e Precoce de ltaquera com uso da técnica do estiolamento de diferentes concentrações de AlB.

Tratamento

número de estacas enralzadas

1 repetiçöes 3

\begin{tabular}{llll}
\hline$C_{1} E_{0} D_{0}$ & 6,0 & 5,0 & 6,0 \\
$C_{1} E_{0} D_{1}$ & 6,0 & 5,0 & 2,0 \\
$C_{1} E_{0} D_{2}$ & 5,0 & 1,0 & 8,0 \\
$C_{1} E_{1} D_{0}$ & 2,0 & 3,0 & 5,0 \\
$C_{1} E_{1} D_{1}$ & 3,0 & 4,0 & 9,0 \\
$C_{1} E_{1} D_{2}$ & 3,0 & 9,0 & 7,0 \\
$C_{2} E_{0} D_{0}$ & 4,0 & & \\
$C_{2} E_{0} D_{1}$ & 4,0 & 2,0 & 3,0 \\
$C_{2} E_{0} D_{2}$ & 4,0 & 9,0 & 8,0 \\
$C_{2} E_{1} D_{0}$ & 4,0 & 8,0 & 9,0 \\
$C_{2} E_{1} D_{1}$ & 5,0 & 4,0 & 1,0 \\
$C_{2} E_{1} D_{2}$ & 7,0 & 9,0 & 6,0 \\
\end{tabular}

* nümero de estacas por repetição $=10$.

$c_{1}=$ cultivar Mizuho

$D_{0}=$ controle

$c_{2}=$ cultivar Precoce de I taquera

$D_{1}=$ concentração de 2000

$E_{0}=$ Sem estiolamento ppm de $A \mid B$

$E_{1}=$ Com estiolamento

$D_{2}=$ concentração de 4000 ppm de $A \mid B$ 
TABELA 16. Nümero de estacas de ramos herbáceos de pitangueira enraiza das de materiais juvenil e adulto com diferentes concentraçōes de AlB.

Tratamento

nüriero de estacas enraĺzadas

$1 \quad 2$ repetições

4

Material Juvenil

$\begin{array}{lrrrr}M_{1} T_{0} & 5,0 & 7,0 & 10,0 & 6,0 \\ M_{1} T_{1} & 6,0 & 10,0 & 6,0 & 5,0 \\ M_{1} T_{2} & 5,0 & 3,0 & 6,0 & 6,0 \\ M_{1} T_{3} & 7,0 & 8,0 & 9,0 & 8,0\end{array}$

Material Adulto

$\begin{array}{lllll}M_{2}{ }^{\top} 0 & 2,0 & 0,0 & 0,0 & 1,0 \\ M_{2}{ }^{\top} 1 & 0,0 & 1,0 & 2,0 & 4,0 \\ M_{2}{ }^{2} 2 & 1,0 & 1,0 & 1,0 & 1,0 \\ M_{2}{ }^{2} & 4,0 & 2,0 & 4,0 & 3,0\end{array}$

* Número de estaca por repetição $=10$

Onde

$M_{1}=$ Material juvenil

$M_{2}=$ Material adulto

$T_{0}=$ Controle

$T_{1}=$ Concentração de 1000 ppm de AlB

$T_{2}=$ Concentração de $2000 \mathrm{ppm}$ de $A / B$

$T_{3}=$ Concentração de $4000 \mathrm{ppm}$ de AlB 
TABELA 17. Nümero de estacas de raízes de nogueira pecã enraizadas de materiais juvenil e aduito, com di ferentes diâmetrós das estacas.

\begin{tabular}{lcccc} 
Tratamento & \multicolumn{4}{c}{$\begin{array}{c}\text { nümero de estacas enraizadas } \\
\text { repetiçóes }\end{array}$} \\
\hline$M_{1} D_{1}$ & 8,0 & 7,0 & 8,0 & 8,0 \\
$M_{1} D_{2}$ & 10,0 & 9,0 & 10,0 & 10,0 \\
$M_{1} D_{3}$ & 10,0 & 10,0 & 10,0 & 10,0 \\
$M_{2} D_{1}$ & 2,0 & 0,0 & 1,0 & 0,0 \\
$M_{2} D_{2}$ & 3,0 & 4,0 & 3,0 & 3,0 \\
$M_{2} D_{3}$ & 4,0 & 3,0 & 3,0 & 2,0 \\
\hline
\end{tabular}

* Nümero total de estaca por repetição $=10$.

Onde:

$$
\begin{array}{ll}
M_{1}=\text { Material Juvenil } & D_{1}=\text { Diâmetro de } 0,5 \text { a } 1,0 \mathrm{~cm} \\
M_{2}=\text { Material Adulto } & D_{2}=\text { Diâmetro de } 1,0 \text { a } 1,5 \mathrm{~cm} \\
D_{3}=\text { Diâmetro de } 1,5 \text { a } 2,0 \mathrm{~cm}
\end{array}
$$


TABELA 18. Nümero de estacas de raízes de pitangueira obtidas de materiais juvenil e adulto com diferenres diametros e colocadas para enraizamento em diferentes substratos.

Tratamento

nümero de estacas enraizadas

2

Material Juvenil

$\mathrm{M}_{1} \mathrm{~S}_{1} \mathrm{D}_{1}$

$\mathrm{M}_{1} \mathrm{~S}_{1} \mathrm{D}_{2}$

1.

$\mathrm{M}_{1} \mathrm{~S}_{2} \mathrm{D}_{1}$

$\mathrm{M}_{1} \mathrm{~S}_{2} \mathrm{D}_{2}$

$\mathrm{M}_{1} \mathrm{~S}_{3} \mathrm{D}_{1}$

$\mathrm{M}_{1} \mathrm{~S}_{3} \mathrm{D}_{2}$

$\begin{array}{ll}2,0 & 3,0 \\ 2,0 & 2,0 \\ 1,0 & 2,0 . \\ 1,0 & 3,0 \\ 1,0 & 2,0 \\ 1,0 & 2,0\end{array}$

Material Adulto

$M_{2} S_{1} D_{1}$

0,0

0,0

$\mathrm{M}_{2} \mathrm{~S}_{1} \mathrm{D}_{2}$

1,0

0,0

$\mathrm{M}_{2} \mathrm{~S}_{2} \mathrm{D}_{1}$

0,0

1,0

$\mathrm{M}_{2} \mathrm{~S}_{2} \mathrm{D}_{2}$

0,0

0,0

$\mathrm{M}_{2} \mathrm{~S}_{3} \mathrm{D}_{1}$

$\mathrm{M}_{2} \mathrm{~S}_{2} \mathrm{D}_{2}$

1,0

0,0

0,0

0,0

* Nümero total de estaca por tratamento $=10$

$$
\begin{aligned}
& M_{1}=\text { Mateiral Juvenil } \\
& M_{2}=\text { Material Adulto } \\
& S_{1}=\text { Substrato areia } \\
& S_{2}=\text { Substrato terra } \\
& S_{3}=\text { Substrato vermiculita }
\end{aligned}
$$

\section{Material Juvenil}

$D_{1}=$ Diâmetro menor que $0,5 \mathrm{~cm}$

$\mathrm{D}_{2}=$ Diâmetro maior que $0,5 \mathrm{~cm}$

Material Adulto

$D_{1}=$ Diämetro menor que $1,0 \mathrm{~cm}$

$D_{2}=$ Diametro maior que $1,0 \mathrm{~cm}$ 